[第31回総会宿題報告]

\title{
胸部撮影法の基礎的研究
}

\author{
東京都立府中病院 \\ 竹吉 干 市
}

(Code No. 21251)

\section{BASIC RESEARCH FOR CHEST RADIOGRAPHY}

\author{
By SENICHI TAKEYOOSHI \\ Tokyo Metropolis Fuchu Hospital
}

\section{Summary}

The X-ray chest radiography is most frequent used in all X-ray radiography, however, it happened many times that problems are raised at a case of diagnosis for the reason of becoming degraded into habit from the monotonous of the work.

This report contained the present condition of chest radiography in our land, its problems and opinions, furthermore practical geometrical subjects, emulsion, granular quality, contrast media, scatter radiation, the system of exposing value controlled.

Thus, there have been so many problems on chest radiography and also it is recognized that gap is found between the theory and practice, particularly the problems of: wave form on secondary switched 3 phase 12 pulse system, of photo timer, of divided measurement method of light value on the exposing value controlled system and of saving the exposing value with quality of radigraphy depended on each type of equipment, then its explication of these problems and study by the comparative method.

Especially for saving the exposing value, the problems happened between less exposing value and quality of radiography are against each other, so actually considering the exposed value, the diagnosis should be given prority, particularly on chest radiography it should be planned to make further progress of technology and quality of radiography.

\section{目次}

1. 緒言

2. 胸部撮影法の現状について

3. 主として実験使用した器材

4. 基礎的諸問題

4-1 幾何学的不鋭

4-2 運動的不鋭

\section{4-3 感光材料による不鋭}

5. 増感紙による諸問題

5-1 濃度の特性曲線

5-2 増感紙の感度比

5-3 增感紙の MTF 之細線法

5-4 増感紙による識別 
5-5 チャートフィルム間距離と焦点による識別

5-6 角度による識别

5-7 傾斜フィルムによる識別

5-8 入射角度による識別

5-9 小括

6. 胸部写真の粒状性における諸問題

6-1 粒状性の基礎実験

6-2 小 括

6-3 濃度による粒状性

6-4. 低濃度部の粒状性

6-5 自現装置による比較

6-6 X線装置による比較

6-7 フィルムによる比較

6-8 感光材料の組合せによる比較

6-9 小 括

7. 散乱線除去に対する諸問題

7-1 グリッド濃度斑について

7-2 散乱線含有率について

7-3 実験装置並びに器材

7-4 実験方法

7-5 測定結果

7-6 フィルタの影響

$7-7$ 考 察

7-8 グりッドの使用露出倍数

7-9 立証実験

7-10 密度による比較

7-11 小括

8. 気管支造影法における諸問題

8-1 造影剤の粘着力

8-2 造影効果の比較

8-3 小 括

9. 3 相 12 パルス装置に扔ける諸問題

9-1３相12パルス装置の波型について

9-2 波型の歪み

9-3 投入電圧の異常

9-4 写真効果からみた投入電圧とタイマの測定法

9-5 タイマの簡易計算法

9-6 応用法

9-7 小 括

10. 螢光量による装置の実測について

10-1 多重絞りのアル々厚について

10-2 装置別螢光量特性曲線

10-3 半価層相当アルミ厚について

10-4 多重使用時の半価層相当アルミ愿について
10-5 小括

11. 単相と 3 相の比較

11-1 線量比較

11-2 管球容量认よる比較

11-3 コントラストについて

11-4 立証実験

11-5 小括

12.胸部写真における優良性の基本的な関係

13。良好なる胸部写真を得る要件

14. 線量制御法の諸問題

14-1 線量制御法の沿革

14-2 線量制御法の原理

14-3 受光部の型式と吸収特性

15. 単相用ホトタイマの諸問題

15-1 パルスにおける誤差

15-2 MGS 方式と SCR の特性比較

15-3 受光部の材質による特性

15-4 分割測光式について

15-5 完全自動式について

15-6 ホトタイマの濃度差

15-7 濃度補正について

15-8 調整特法曲線

15-9 濃度過多に学る場合の補正

15-10 濃度が薄くなる場合の補正

15-11 ポジショニングによる濃度差

15-12小 括

16. 3 相用ホトタイマの諸問題

16-1３相用ホトタイマの特性

16-2 ホトタイマの問題点

16-3 散乱線とホトタイマ

16-4 小括

17. 3 相装置の識别について

17-1グリッドなしの示現

17-2 グリッド法の示現

17-3グリッド法による増感紙の示現

17-4 グレーデル法の示現

17-5 低濃度部の識別能

17-6 小，括

18. 被曝量の問題について

18-1 単相装置による空中線量

18-2 グリッド使用時の単相装置における線量

18-3 単相装置による管電圧の減少率について

18-4 3相12パルスによる線量

18-5 電圧による減少率 


$\begin{array}{ll}18-6 & 1 / 2 \text { 螢光量による線量 } \\ 18-7 & 3 \text { 相と単相の線量比較 } \\ 18-8 & \text { 立証実験 } \\ 18-9 & \text { 写真効果からみた線量 } \\ 18-10 & \text { 考 察 } \\ 18-11 . \text { 小 括 }\end{array}$

1. 緒一言

胸部疾患におけるX線榜断の歴史は古く 1897年 Williamsによって試みられ，同年増感紙も使用され初め， 1933年タングステン酸カルシウムが用いられるようにな った. 又X線装置煘応コイル型加ら1901年には水銀断 続器が登場，1906年頃から交流が用いられるようになり， 1908年Snook による 機械整流の 発明で同期電動器と組 合せ, $100 \mathrm{kV}, 100 \mathrm{~mA}$ の装固の 開発により䐧部僢間撮 影の飛躍的発展への基礎となった.1913年には G. Buky のクロス Grid の考按続いて1915年特許申請や1916年 H. Potter による焦点外X線の減少方法の発表, 又臨休面で は1924年には Weber による胸部の硬線撮影法の報告, 翼1925年には Chantraine による低電圧 大電流方式によ る軟線撮影法の強調以来一般的には，いわゆるコントラ ストに富んだ白黒の写真が胸部の理想的なものとみなさ れて来た.而し短時閴撮影にはX線管の負荷や被検者の 被曝の点からとれに対処する必要上高電圧技術の研究が 真剣にとりあげられた. 1929年 J. stephani は $150 \mathrm{kV} に$ よる高圧撮影法を試み撮影時間の短縮と兴断価值が従来 の低電圧撮影をむしろ凌駕する事を報告している．本邦 においても日本放射線技術学会第 3 回総会において徳島 疾専の岡橋氏等によって高電国による遠距樆推撮影法が報 告され，1953年には九大尾関博士等による $140 \mathrm{kV}$ 高圧 撮影法の報告, 新大泚谷氏等による胸部の高電压撮影の 実験があり，その後幾多の報告がなされ現在に至ってい るが, 今日尚, 日常のX線診断に捣いて, しばしば問題 が提起されるのも胸部のX線写真に比較的多い. そこで 出来る限り実際に直結した問題を取り上げ検討を試みた。 更に近年放射線による国民遺伝有意線量の增加にともな り医療被曝問題として胸部撮影時におけるグリッド使用 の是非が論議されるようになった。よって現状把握の為 アンケートによる調査と従来比較的慣習に流され勝ちで あつた面の反省と日常業務の再点検及び装置による問題 の解明, 特に单相と 3 相 12 パルスの問題, 線量制御法, $\mathrm{X}$ 線装置の型式による被曝量の問題等について比較検討 を試みた。

19. 撮影体位と障害陰影

20. 肺野にお汀る骨陰影の比率

21. 胸部写真における読影の要点

22. 臨床写真について

23. 総括, 結言

24. 謝 辞

\section{2. 胸部撮影法の現状について}

調查の対象 胸部撮影法の実態を究明する目的で全国 都道府県別に複数の施設に依頼してアンケートによる調 查を実施した．調查施設は196 施設で内回答数は146通, 回収率 $74.5 \%$ で, その施設別内訳は病院 $68.5 \%$, 療養所 $19.2 \%$, 診療所その他 $12.3 \%$ あった．次に病床数につ いては病院療養所別に区別分類してみると，Fig. 1 のよ

\begin{tabular}{|c|c|}
\hline 病 院 & 部 \\
\hline 150 未満 & $8 \%$ \\
\hline $\begin{array}{c}151 \sim 300 \\
\text { 床 }\end{array}$ & $16 \%$ \\
\hline $\begin{array}{c}301 \sim 450 \\
\text { 床 }\end{array}$ & $24 \%$ \\
\hline $\begin{array}{c}451 \sim 700 \\
\text { 床 }\end{array}$ & $25 \%$ \\
\hline $\begin{array}{c}701 \sim 1,000 \\
\text { 床 }\end{array}$ & $21 \%$ \\
\hline 1,001 以上 & $6 \%$ \\
\hline
\end{tabular}
療養所の部

\begin{tabular}{|c|c|}
\hline 150 未満 & $3.5 \%$ \\
\hline $\begin{array}{c}151 \sim 300 \\
\text { 㕅 }\end{array}$ & $21 \%$ \\
\hline $\begin{array}{c}301 \sim 450 \\
\text { 㕅 }\end{array}$ & $39 \%$ \\
\hline $\begin{array}{c}451 \sim 700 \\
\text { 㕅 }\end{array}$ & $29.5 \%$ \\
\hline $701 \sim 1,000$ & $3.5 \%$ \\
\hline 1,001 以上 & $3.5 \%$ \\
\hline
\end{tabular}

Fig. 1 病床数による分類

うになり病床数は病院が $451 〜 700$ 床の姏が最も多く $25 \%$ で，爒羪所においては301〜450床加39\%で最す多い。近 年結核による死亡者の減少と共に療養所における病床数 の減少は著しく, 反対に病院の病床数が非常に多くなっ ているのが最近の現状である.

\section{診断用 $\mathbf{X}$ 線装置}

\section{と技師数について}

調查結果としては 診断用X線装置は 多くが単相用装置 であったが 3 相装 置は33施設で使用 し, 徐々にではあ るが単相から 3 相 への過渡期飞人っ

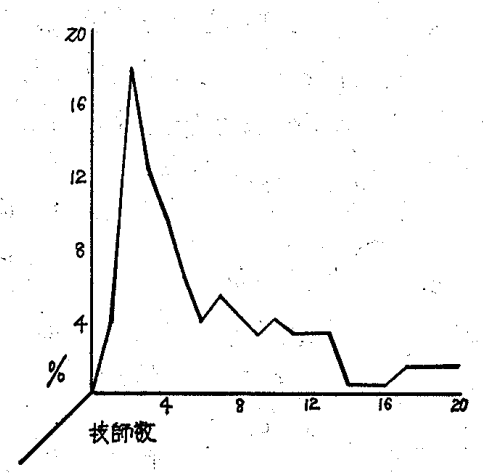

Fig. 2 技師数による施設分類 
た感がする。その他 3 施設が蓄放式装置を併用していた。 又装置台数については 1 施設 2 台以内が約 $60 \%$ で, 最も 多い処では17台以上を使用している施設もあった。次に 技師数は Fig. 2 のように $2 \sim 3$ 名の施設が最も多く， 病院では20名以上の施設すかなりの数に達しているが， 療養所に於ては 7 名の施設が最高であった。

使用器材について 胸部X線写真に影響する附属品の 調查では多重絞りについては調查中， 1 亿 2 の例外を除 き全部の施設で使用しており，その他の器材については 次の通りである.

$\mathbf{X}$ 線管焦点 胸部写真の幾何学的問題を左右する使用 焦点の大きさは焦点 $2 \mathrm{~mm}$ を使用している施設が $60 \%$ と 多数で, $1.2 \mathrm{~mm}$ 未満の X線管を使用している施設は約 $20 \%$ であった。調査中 $1 \mathrm{~mm}$ 焦点と $2 \mathrm{~mm}$ 焦点の併用は $12.3 \%$ あった。 次に胸部側面撮影 用に使用している 焦点は, Fig. 3 の ように分類される が， $2 \mathrm{~mm}$ 焦点が ，

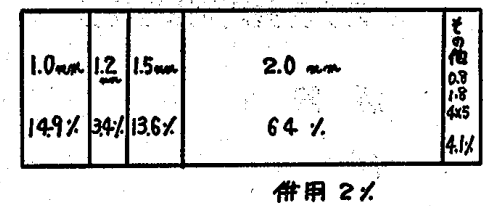

Fig. 3. 側面用焦点の大きさ 64\%と更に堌加している.とれはX線量の増加による当 然の結果で, $0.9 \mathrm{~mm}$ 未満のX線管の使用は非常に少ない.

増感紙 調査時点における使用増感紙は, Fig. 4 のよ うにFS 增感紙か $54.5 \%$ 之過半数で，次に MSの14\%で

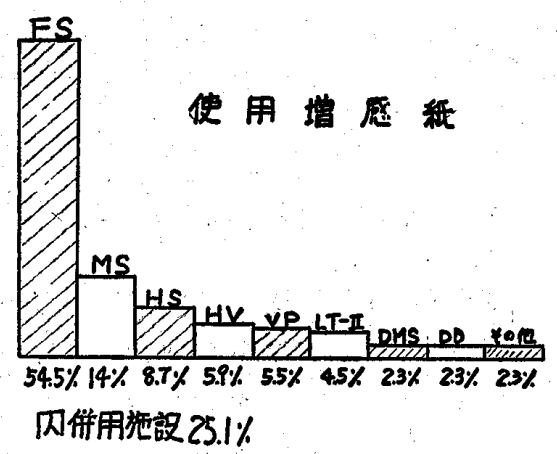

Fig. 4. 使用増感紙

ある。また各種増感紙と併用している施設が25\%で，側 面用増感紙としては FS が正面に比し稍々少なく $44.2 \%$ て，FSが減少した分だけ MS と HSの使用率が高くな っているのが現状 である。

グリッドの使用 状況 胸部撮影時 にグうッドを使用 している施設は

Table. 1 で68.5\%
Table. 1 胸部撮影時のグリッド 使用

\begin{tabular}{crr}
\hline 使用する & 100 施設 & $68.5 \%$ \\
使用しない & 46 施設 & $31.5 \%$ \\
計. & 146 施設 & $100 \%$ \\
内内併用施設 & 28 施設 & $19.1 \%$ \\
\hline
\end{tabular}

と圧倒的多数であった.

グリッドの格子比と密度 使用グリッドの格子比につ いて分類したが， $8: 1$ が最も多く $27.5 \%$ ，次に10:1 が $21.8 \% ， 12: 1$ が20.6\%，5:1 が17.4\%，6:1 が11.4\% である. 又使用電圧によりグリッドの格子比を区別して いる施設が16.5\%含まれていた。

次に格子密度については，34本/cm が41.6\%，次に28 本 $/ \mathrm{cm}$ が18.6\%，40本/ $\mathrm{cm}$ が15.1\%，26本/ $\mathrm{cm}$ が15.1 \%であるが，側面撮影時は 28 本/ $\mathrm{cm}$ が $21.4 \%$ と増加し， その分だけ34本/ $\mathrm{cm}$ が減少している。しれは移動グリッ ドの使用が多くなっているものと推察される.

胸部撮影台、使用撮影台については, Fig.5 のように， リーダー撮影台が最す多く使用され $37.2 \%$, 次で格子往

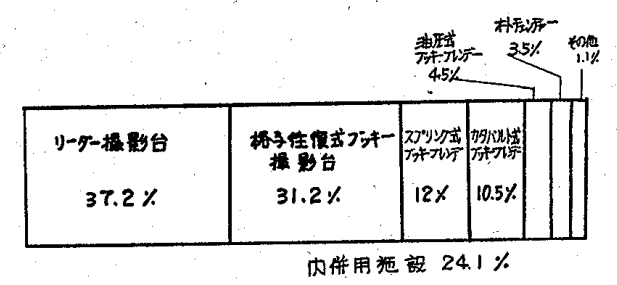

Fig. 5. 使用撮影台

復式, スプリン゙グ式撮影台, その他ブッキー撮影台の順 で，グリッドを使用している撮影台を全部合せると約 62 \%になる。

撮影距離 胸部撮影距離については，F.F.D $200 \mathrm{~cm}$ $62 \%$ と多く，続いて $180 \mathrm{~cm}$ が17.7\%，150 cm が17\%で あるがとの中で胸厚距離法を使用している施設が11.4\% である．次に側面撮影距離についてみると，F.F.D 200 $\mathrm{cm}$ は29\%と正面撮影比し，半分以下に減少し，反面 F.F.D $150 \mathrm{~cm}$ は $42.5 \%$ 倍以上に増加している.とれ は装置の容量その他に関係するが，側面撮影距離は 150 $\mathrm{cm}$ 末満が約 $50 \%$ 以上になる。

使用フィルター 胸部撮影時の使用 フィルターは,

Fig. 6 の通り非常 亿多種類を使用し ているのが現状で ある。

線量制御法 胸

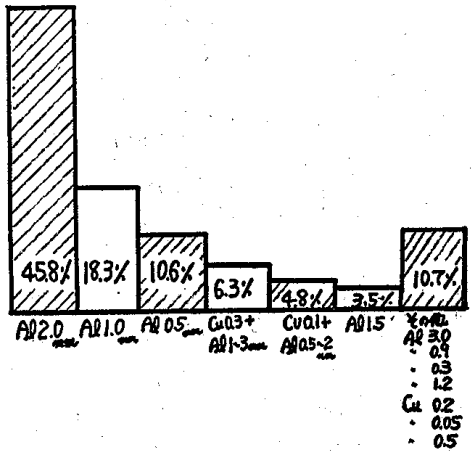

Fig. 6. 使用フィルターの擪さ 部撮影時における線量制御法は，30.6\%の使用率で内小

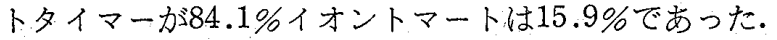

撮影条件 正面撮影について，被写体は成人男子 20 $\mathrm{cm}$ の胸厚についての調查で管電圧, 管電流，撮影時間 
别に分類集約したが，管電圧においては61〜 $75 \mathrm{kV}$ が最 あ多く27.7\%，次に76〜90 kV が22\%であった。よって $90 \mathrm{kV}$ 以内の撮影電圧が約 $55 \%$ あ゙あ. 又 $141 \mathrm{kV}$ 以上 の高電圧を使用している施設が16\%以上ある事む一つの 特色である. 次㳊管電流についてみると $151 \sim 200 \mathrm{~mA}$, が最も多く30.4\%，次に201〜300 mA が26.2\%である. よって $151 \mathrm{~mA}$ 以上が拉よそ70\%になる.撮影時間につ いては0.04 0.05秒が $34.2 \%$, 次汇0.06 0.08秒か 33.6 \%，したがって約 $80 \% は 0.08$ 秒以内で撮影しているのが 現状である。

側面撮影について 胸部側面撮影は, 撮影管電㞋は, $126 \sim 140 \mathrm{kV}$ が27.8\%で, 次に $111 \sim 125 \mathrm{kV}$ が20.1\%, したがって胸部正面撮影条件とは反対に $111 \mathrm{kV}$ 以上が 約 $60 \%$ である.しかし $80 \mathrm{kV}$ 末満む $14.6 \%$ ある. 次に 管電流は $151 \sim 200 \mathrm{~mA}$ が $46.3 \%, 51 \sim 100 \mathrm{~mA}$ が $23.1 \%$ と, 使用電流 $200 \mathrm{~mA}$ 末満か $70 \%$ 以上あるととも正面像 とは対象的である. 側面撮影時間は 0.1 秒を境に略々 2 等分出来る.

撮影体位 胸部撮影体位については手に腰をあてる方 法が最む多く55.7\%，次に撮影台をだかせる方法か335.6 \%で，乙の体位は老人に利用している施設が多い。

前後方向における中心 $X$ 線の位置 腹背方向撮影時の 中心線の位置は, フィルム中央が $41.6 \%$ と最む多く, 次 に胸骨柄にむけフィルムに直角の施設が $34.5 \%$ である. また中央やや上から斜下方方向分 $9.1 \%$ あった.

生殖腺防護について 脸部撮影時における生殖腺の防 護については，防護ありと答えた施設は $57 \%$ ，ない施設 は $40.3 \%$ での内，弤婦のみ防護している施設が $2.7 \%$ であった．次に防護方法は Table.2の通りで，鉛布に よる腰巻きが最も多い. 又多重で防護と答えた施設も 19

Table. 2 防 護方 法

\begin{tabular}{lr}
\hline \hline 1. 鉛布による腰巻 & 19 \\
2. 妊婦は含鈆ゴム & 14 \\
3. 防護スカート & 8 \\
4. ゴム前掛で覆う & 7 \\
5. 多重シャッターに鉛板をつける & 5 \\
6. 鉛ゴム衝立 & 3 \\
7. 小昌のみゴム前掛 & 3 \\
8. 腰全体を鉛ゴムで覆う & 2 \\
9. 羽农で防護 & 2 \\
10. アジヤステリングスタンドプロテクター \\
11. 高低可変の防護車と自作防護台の併用 \\
12. 専用プロテクターをブッキー台に取付け \\
13. 多重で防護 \\
\hline
\end{tabular}

\section{件あった。}

肺尖撮影法について 肺尖撮影法については大別して 鎖骨を肺外に出す方法と，上肺野に下げる方法とがある が97\%は肺尖汇出す方法で僅が $3 \%$ が关の他の方法で ある. 次江鎖骨を脑外飞出す方法の内 $91.4 \%$ が後彎法で その他は $8.6 \%$ ある。撮影距離については $150 \mathrm{~cm}$ が, $48.5 \%$ あった. 又との撮影法のグリッドの使用率は $61.3 \%$ あるる。

肺尖撮影の使用頻度 最近肺尖撮影法の使用頻度は少 ないと答えた施設が 88.4 \%で, 多いは僅加に3\%。 で参考までに胸部撮影 100 枚中の割合を表にし たものが Fig.7である.

中葉部撮影法 フライ

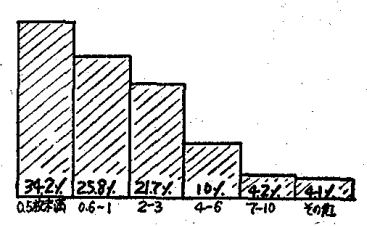

Fig. 7. 胸部撮影 100 枚中 肺头撮影の割合 シュネル氏の陷道による撮影法が古くから用いられてい たが最近の撮影法は叉腔位撮影法を含めて $7.8 \%$ の使用 率である。乙の中，前後方向で摄影する処が $82 \% ，$ 後前 方向は18\%であった。

肺底撮影法 横 隔膜との境付接す る病垐を究明する 為に肺底撮影法が 使用されるが，こ の使用率は $8.5 \%$ である.この中で 前後方向撮影が $70.5 \%$ ある.撮 影角度については

Fig. 8 のように分 類され，撮影距離 は約 $50 \%$ 以上が $150 \mathrm{~cm}$ である. 又 使用頻度の多い施 設でも月注 5 件以 内が大部分である。

拡大撮影法 拡 大撮影法の使用率 は34.5\%で常時使 用しているのは僅 かに1施設のみで あった。使用焦点 は $0.3 \mathrm{~mm}$ が 66.6 \%である.僅かで
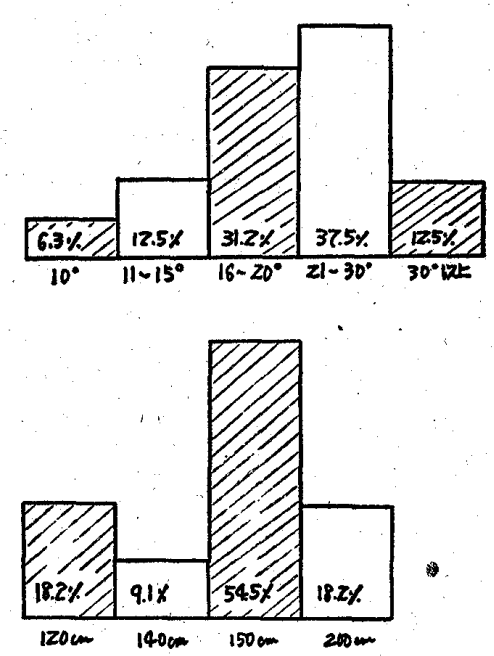

Fig. 8. 肺底撮影時中心線の角度 と距離

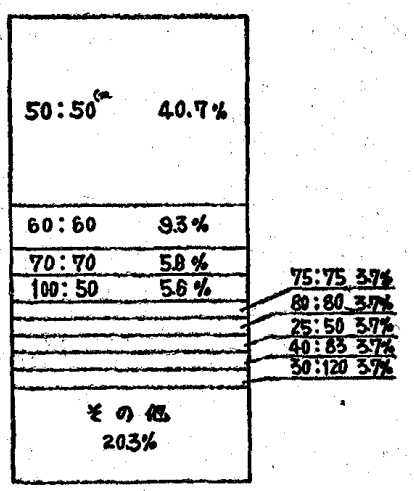

Fig. 9.，拡大撮影距離 
はあるが 1〜2mm 焦点管屯含まれていた，又使用増感 紙は FSが $51.5 \%$, MS が $21.3 \%$, HS が $14.7 \%$ ，その 他 HV，LT-II などであった。撮影体位としては卧位が $54.6 \%$ ，立位が41\%，撮影距離は Fig. 9 で 2 倍拡大が 最む多い. 又若干ではあるが 4 倍拡大を実施している施 設ああった。

立体撮影法 立体撮影法の使用率は $17.3 \%$ で撮影方法 としては管球移動 法が92.5\%で，移 動距離は Fig. 10 のように $10 \mathrm{~cm}$ が 最む多い。観察装

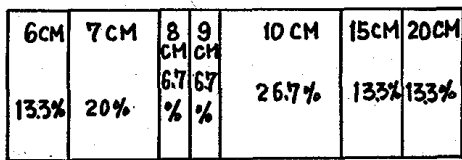

Fig. 10. 管球移動距離
置は $86 \%$ 以上が使用している。

気管支造影法 気管支造影法は保健所は適応なし, 又 診療所は $1 \sim 2$ の施設が実施しているのみで,115施設に より集計した。しかし本法はアンケート集約後造影剂の 製造中止等により現況とは多少異なる事が予測出来る。

造影猎について 気管支造影剤はディオノヂール(46. $2 \%)$ ，ウコリン $(29.6 \%)$ ，ハイトラスト(20.8\%)が大 部分で片脑造影の場合使用量は $11 \sim 15 \mathrm{cc}(32 \%), 16 \sim 20$ $\operatorname{cc}(25.6 \%), 21 \sim 30 \operatorname{cc}(26.6 \%)$, 10cc 以下 $(10.6 \%)$ と なり，11〜15cc が最多かったが，最大 $60 \mathrm{cc}$ の施設も あった．とれはメトラゾンデによる．順次選択気管支分 割注入法を実施している施設と推測される。

注入法と撮影方法について 造影剤の注入手技として は TV 透視下が $67 \%$ あ゙あ，螢光板透視下 $17.5 \%$ ，透視 なし15.5\%である。撮影方法は Fig. 11 のよう TV 透
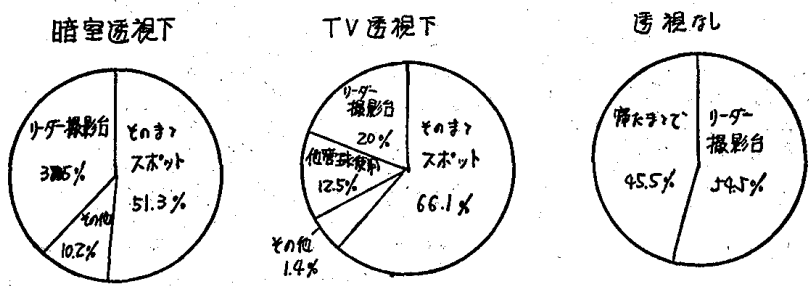

Fig. 11. 造影刜注入撮影について

視では66\%，螢光板透視では51\%がスポット撮影で次に リーダー撮影法が多い。注入器具はメトラーゾンデの使 用が $52.5 \%$ と半数以上で，その他ネラトンが35.1\%であ った。使用増感紙はスポット撮影が多い為か FS が42.6 $\%$ ，MS が36.4\%と中感度の使用率が高い.グリッドは 8:1 が最も多く $41 \%$ あるるが，本法の場合 $8: 1$ 未満の使 用率が70\%である。格子密度は 34 本 $/ \mathrm{cm}$ が最す使用率は 高い.グリッドの使用方法としては移動方法が $62.4 \%$ て ある、撮影距離は $100 \mathrm{~cm}$ までが $48.5 \%$ ，次に $150 \mathrm{~cm}$ で ある。
気管支断層撮影 気管支造影時における断層撮影は使 用している施設は $27 \%$ である。

所要時間 造影剤注入後撮影完了までの時間は $7 \sim 8$ 分で完了が44.7\%で次いで 6 分以内が $27.6 \%, 10$ 分以上 が約 $25 \%$ ある。

胸部撮影法に関する意見 現状における胸部撮影法の

Table. 3 意見の集約方法
1. 被曝量関係
6. 撮影補助具関係
2. 防護関係
7. 撮影技術関係
3. 散乱線除去関係
8. 撮影の自動化
4.フィルター関係
9. 情報関係
5. 多重関係
10. その他

問題点について多数の貴重な意見を頂きましたので今後 の参考にと思い集約分類したものが Table. 3 で，更に この分類より主なる意見を要約したものが Table. 4 で 非常に問題は多くかつ複雑である.

Table. 4. 主なる意見

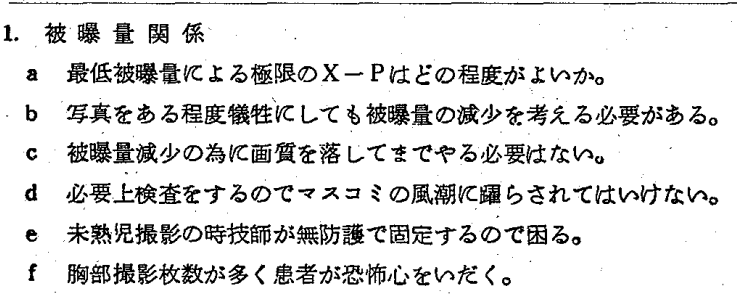

2. 防 護関孫

a 作業能率を理由と無防護は技師の急漫である。

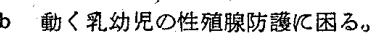

c 小览透視時の防護の開発が必要てある。

d．妊婦は防護スカートを使用するので標示している。

e 鉿ベト $(10 \mathrm{~cm} \times 40 \mathrm{~cm})$ 性殖腺防護になったらと考えている。

f 多重使用時の散乱線湖定結果から胸部撮影時の性殖腺防護壮特に配虑し tho

3. 散乱楾除去関係

a クレーデル法で高氏撮影をする。

b Gridの集束距離 $200 \mathrm{~cm}$ ○のがならので困る。

c 実用的にしまめの見允ない高密度Gridが佁しん。

d 腧部標渒撮影としてGridが必要かどらか。

e 線量の割にGridの使用はメリントが少ない。

f. Gridの使用忟古的概念である。

g 管球ガラス壁直前で鉛マスクで絞る。

h 演正用Grid動作不適当なものが多い。

4. フィルタ一関係

a. 補正フィルターの交換か簡単江出来るすのが陈しい。

b. 特に断層用補正フィルタ一が必要である。

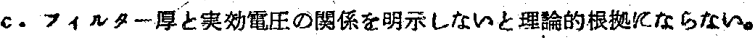

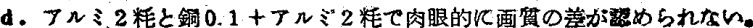

e. 補正フィルターは忘九易い。 


\author{
5. 多雷関係

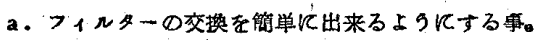

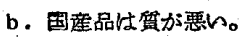 \\ c.多重の精度を向上させる事。 \\ d．多重の法的规制を希望する。

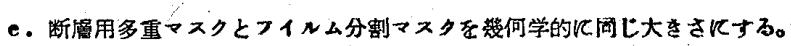

\section{6. 摄影補助具関係}

a. あらゆる装埴器具の法的義务を目わせる事。

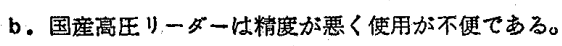

c. 小児の立位撮影台の固定が悪ら。

d. 泣きあばれる小児用固定具が市販のものては不備て使用出来ない。

e ，小睍用固定具の開発を希望する。

f . 小睍用《移動梨置を開発、好結果を得ている。

g. 画澌の向上飞撮影用補助具の開発が必要である。

h，小垐撮影時の呼吸停止装膡の開発。

\section{7. 撮影技街関係}

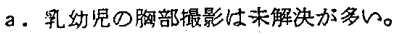

b．1台の装置て作業量が多くすへて簡略主義である。

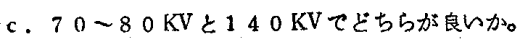

d. 木トタイマーKより精度が異なるのて $140 \mathrm{KV}$ を使用。

e. 夏冬の水温化上り写真の潾度加異なる。

f，不必要と思われる摄影枚数が増加の傾向にある。

g. フイルム・メーカーによる感材特性の違加ら肉眼的写真美を感しる。

h 。撮影の為、胸部 4 万向バリウムの服用が多くて困る。

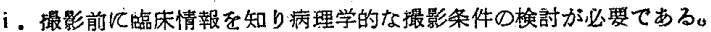

8. 撮影の自動化

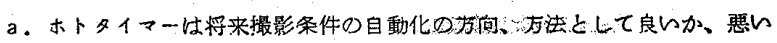
加。

b、ホトタイマーの特性の娭討が完全になされていない。

c. 経験的な専門家よりホトタイマーの方が涱度が一定している。

9. 情 報関係

a．新聞「Vで防護のPRをする必要がある。

10. ₹曲地

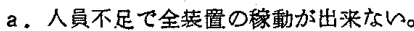

b．攝影枚数の多いのは一部医師のモラルにる問題がある。

考察 以上の点を考察するに戦後30年を経過しX線管 球も固定陽極加ら回転陽極に変りグリッドの使用率 屯 $68.5 \%$ を数え，戦前に比しかなり高い電圧が使用される ようになったが，尚低いものが多く，又撮影距離，管電 流は比較的大きく短時間で撮影しているのが実状である. したがって焦点は回転陽極といえども比較的大きいもの を使用しなければならず必然的な結果として $2 \mathrm{~mm}$ 焦点 の使用率は高い。又胸厚 $20 \mathrm{~cm}$ ，成人男子の撮影条件む 非常に多種多様である. 次にフライシュネル, 肺底, 撮 影法等は使用率は少なく, 肺尖撮影法も㛝戦後の結核全 盛期に比し約 $1 / 100$ 程度の使用率である．乙れは断層装 置之回転陽極X線管の普及とグリッド使用による高王化 による画質の向上による結果と考えられる. 又気管支造
影法は造影剂の進歩と注入法の改善等によりかなり進歩 を遂げたが現在尚造影剤による副作用と患者の苦痛の為, 更に肺結核症の外科的手術の減少と共に使用率も減少し た，最近非結核疾患の鑑別誩断に多く使用されるように なったが，企業の採算性と併せて造影剂の種類もかなり 限定されて来た事む現実の問題である：乙の調查汃ら推 測される事は胸部写真は基本的な問題だけであかなり意 見の相違があり，装置，撮影技術，現像，被曝，画質の 問題等, 現実は厳しく, かつ遠い事が予測出来る。

\section{3. 主として実験に使用した器材}

本研究に際し使用した主なる器材は Table. 5 の通り である。

Table. 5 主として実験に使用した器材

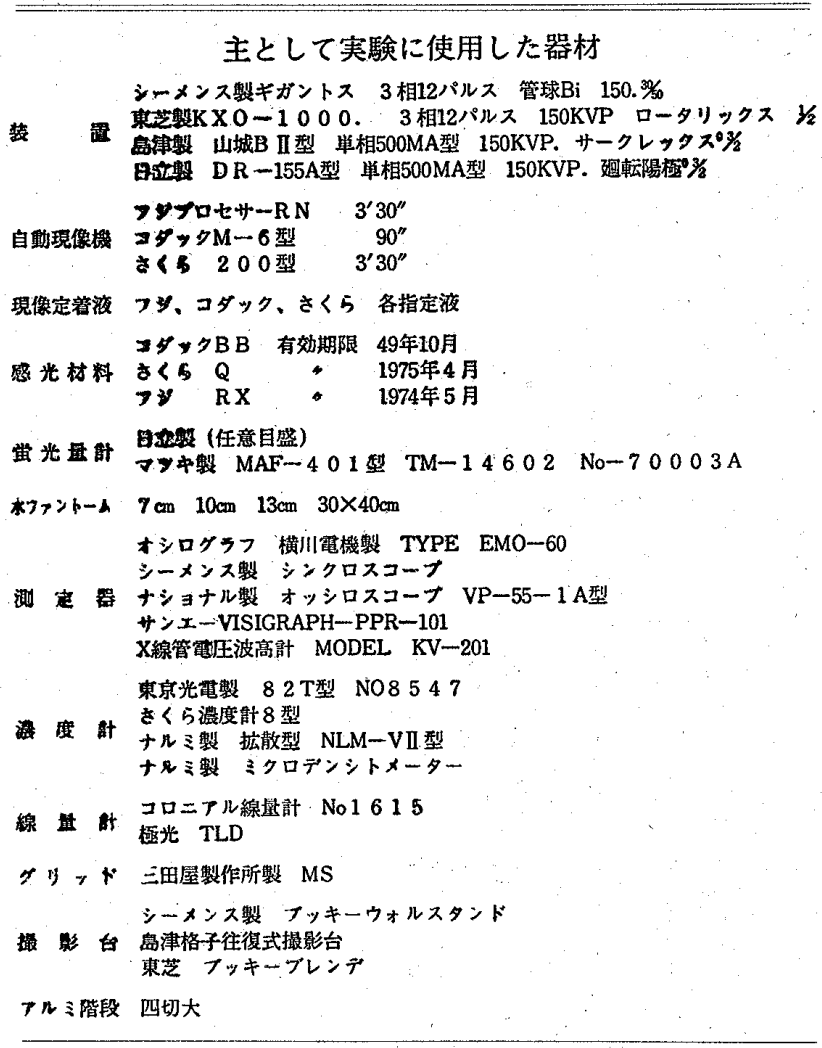

\section{4. 基礎的諸問題}

胸部撮影における肺内の最も小さな型態的变化即ち病 巣の最少単位は腣胞であり，約 $0.1 \mathrm{~mm}$ の球形をなす異 常肺胞をフィルム上に促える事が究極の目的である.而 し臨床的に肺疾患として取扱われる細葉性病巣の大きさ は, 約 $2 \mathrm{~mm}$ でこの病巣をフィルム上に的確に促える事 が当面の課題で努力目標である.

4-1 幾何学的不鋭 周知のように幾何学的不鋭は撮影 距離, 焦点と被写体, フィルム間距離によって左右され 
る. 今胸厚 $20 \mathrm{~cm}$ 之仮定し, 距離による拡大率を比較し てみると Fig. 12 のように拡大率は $200 \mathrm{~cm}$ と $150 \mathrm{~cm}$, で約 0.043 倍, 計 算式のように不鋭 は焦点を小さくす る事が最む效果的 で H. Rein の研究 加認知される不 鋭の限界を $0.1 \mathrm{~mm}$ と仮定し, 厚さ 20 $\mathrm{cm}$, 距離を $150 \mathrm{~cm}$ にすれば $0.6 \mathrm{~mm}$ 末満の管球が必要 である.同一条件 ならば現状の 2

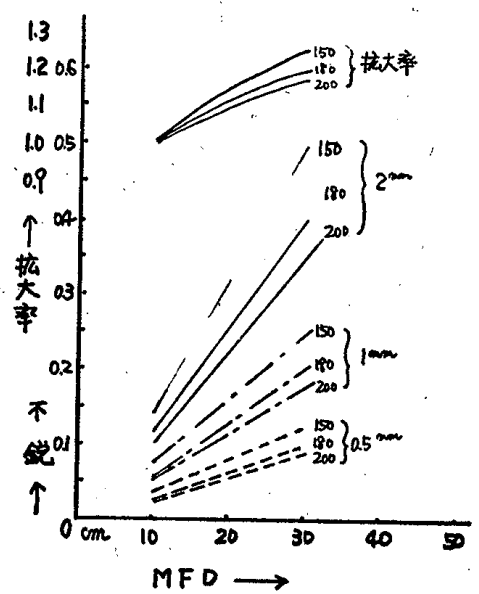

Fig. 12. 拡大率と不鋭 $\mathrm{mm}$ 焦点から $1 \mathrm{~mm}$ 焦点にすれば不鋭は $1 / 2$, 更に 0.5 $\mathrm{mm}$ 焦点になれば不鋭は $1 / 4$ 江改善する事が出来る。

4-2 運動的不鋭 胸部撮影時は運動的不鋭を可及的小 さくする事が必要で理論的には短事間程理想であるが, 実際の撮影時間を何処汇求めるかは装置の問題や被写体

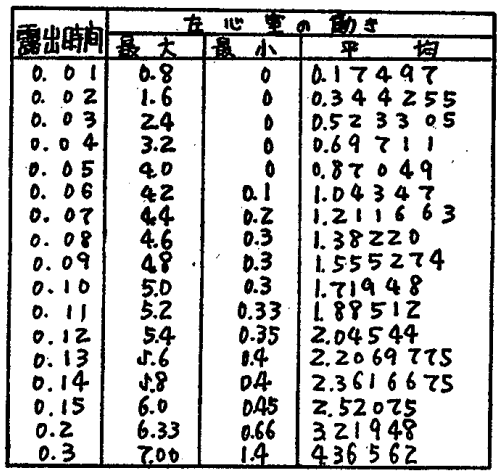
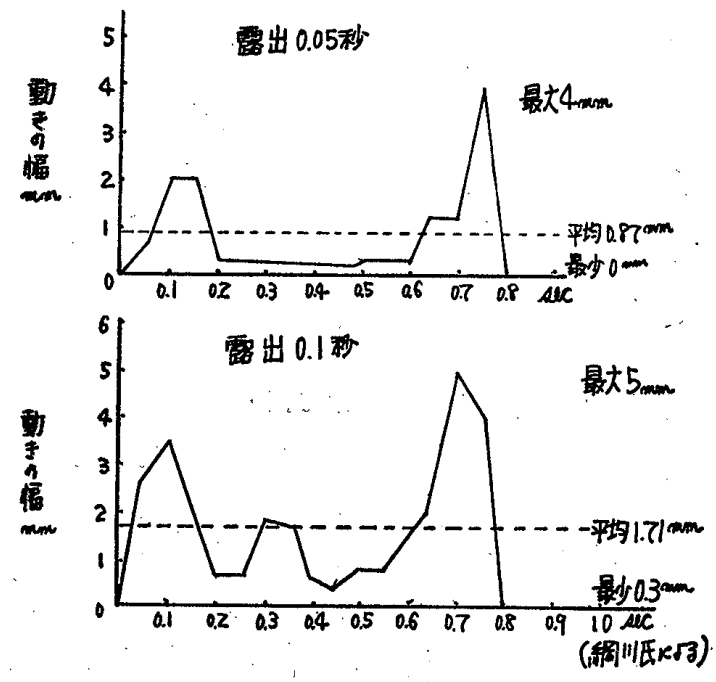

Fig. 13. : 心臟の動き
の厚さ, 感光材料, 現像温度等によって異なるがFig. 13 の綱川氏の計算から撮影時間 $0.1 \mathrm{sec}$ 亿おいて左心室, 最大の動きは $5 \mathrm{~mm}$, 平均 $1.71 \mathrm{~mm}$ である. 又 $0.05 \mathrm{sec}$ においては最大 $4 \mathrm{~mm}$, 平均 $0.87 \mathrm{~mm}$ 動く事になる。 乙 たがって $1 \mathrm{~mm}$ 以内の動きで撮影される可能性は 0.06 sec で約 $50 \% ， 0.05 \mathrm{sec}$ で約 $65 \%$ である。運動的不鋭は 特に線量制御法の場合に問題で充分に撮影時間の配慮が 必要である.

4-3 感光材料による不鋭 胸部写真において増感紙と フィルムを組合せた感光材料を使用すれば必然的に厚さ による不鋭を生ず る, 又不鋭は厚さ によって異なるが Fig. 14 のように (厚さ $\times \tan \alpha)$ で 計算出来る. FS の増感紙で斜入X

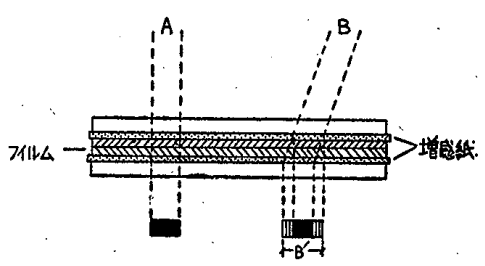
Fig. 14. 斜入X線によるボケ
$\mathrm{B}^{\prime}=\mathrm{t} \cdot \tan \alpha$ 線に対する不鋭は $20^{\circ}$ 。で約 $0.17 \mathrm{~mm}$ である。

\section{5. 増感紙の諸問題}

5-1 写真濃度特性曲線 胸部X線診断に於ては増感紙 の感度と鮮鋭度が重要で, X線写真の濃度は増感紙に影 響する処が極めて大きい. そこで現在使用中の増感紙に ついて散乱線の影響を可及的少なくした実験で現像は恒 温タンクによる指定現像法で処理した．測定結果は電圧 別に $60 \mathrm{kV}, 100 \mathrm{kV}, 120 \mathrm{kV}, 140 \mathrm{kV}$ で Fig. 15〜Fig. 18 である．感度の高い順では HS, HV, MS とLT-2, FS と なる．而し濃度曲線の傾向としてはその差は比較的少な W.

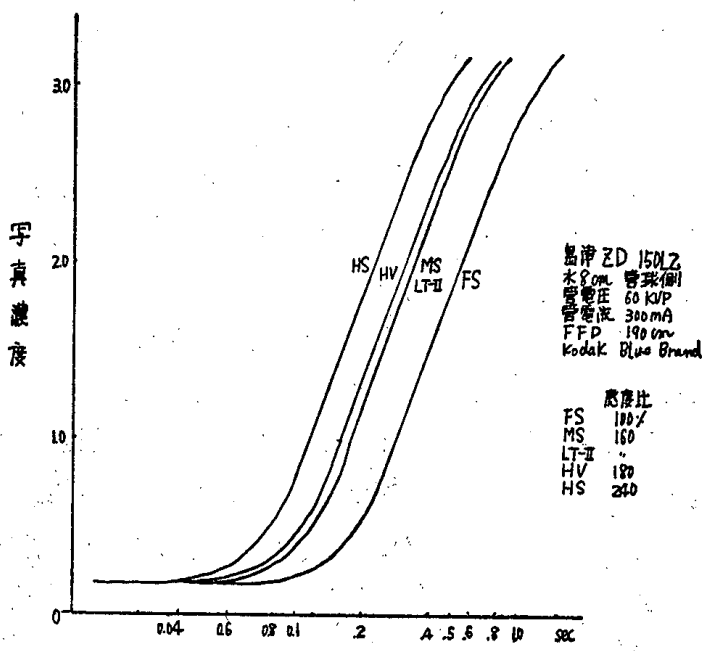

Fig. 15 . 

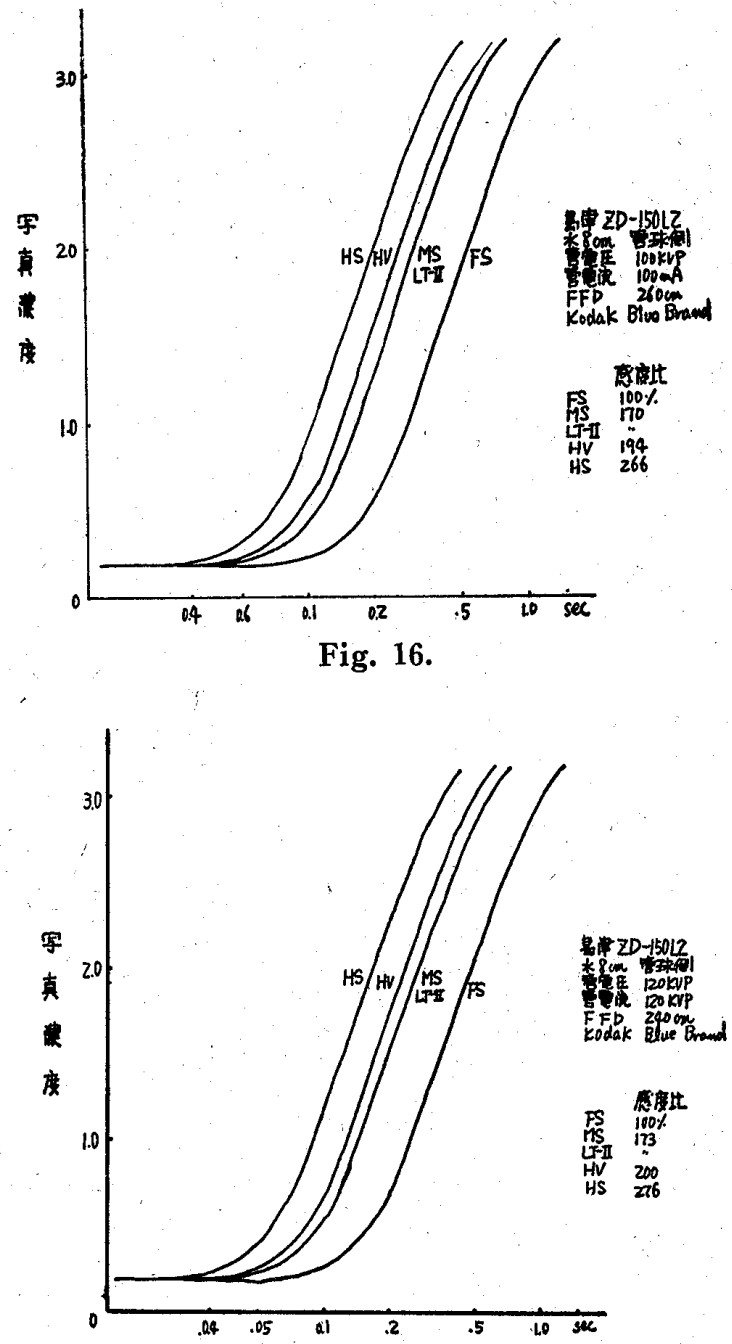

Fig. 17.

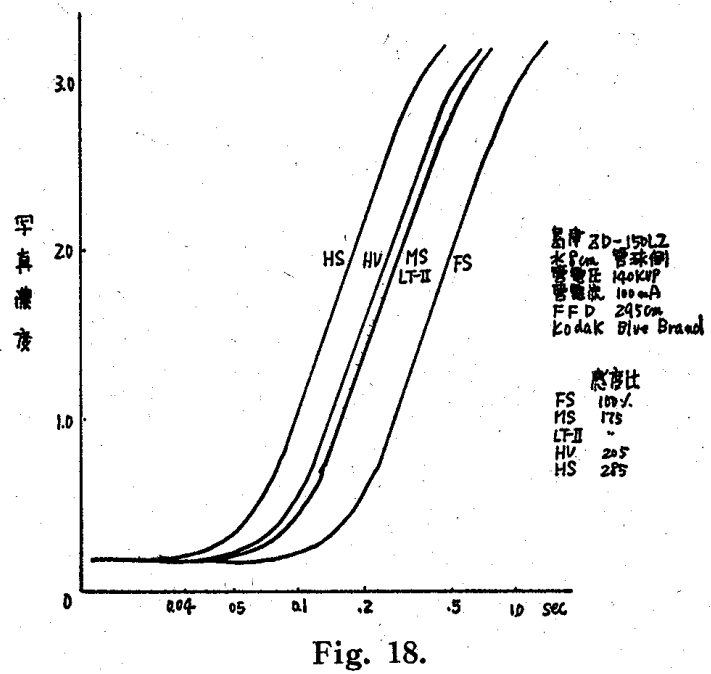

5-2 增感紙の感度比 写真濃度特性曲線汃ら時間の逆 数をとれば感度比を求める事が出来る. 感度比は電圧の 上昇と共に多少高くなる.而しとの実験は出来るだけ焦
点外等の散乱線による影響を除外した実験で実際には装 置と現像温度, ファントムと含気組織の違い, 管電王等 による散乱線の寄与率により, 感度比 $+\alpha$ となる。した がって胸部撮影の場合, 略々 1 対 2 の感度比で実用され る.而し $90 \mathrm{sec}$ 現像等により現像温度の高い姏理方法の 場合には $\alpha$ の值は異なる。.Fig. 19 は LT-2 の堌感紙を

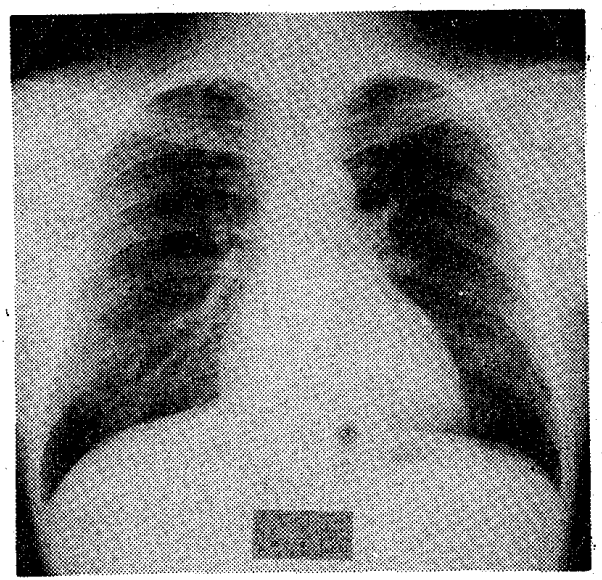

Fig. 19.

使用してFS の略々 $1 / 2$ にした奏験写真で濃度的にも FS に殆んじそん色がない。使用管電圧 $125 \mathrm{kV}, 50 \mathrm{~mA}$, 3 相 12 パルス，胸部用自現装置で 3.5 分現像.

5-3 増感紙の MTF と細線法 增感紙の鮮鋭度の評価 法として通信の世界で発達した MTF が導入されるよう になった．実測に当って大部分は矩形波チャートを使用 して撮影し，その濃度をFig. 20 のようにミクロホトメ ーターで測定の上一定の系数処理で作図した.Fig. 21は 現在最む使用率の高い各種堌感紙の MTFで, FS が 最 あよく，LT-2の順である．しかしMTF はX線像成立 の基本であるX線減弱の差による配慮が比較的少ないの で臨床における基礎実験として示現の限界を細線法によ って求めた。実験に使用したチャートは $0.06 \mathrm{~mm}$ から

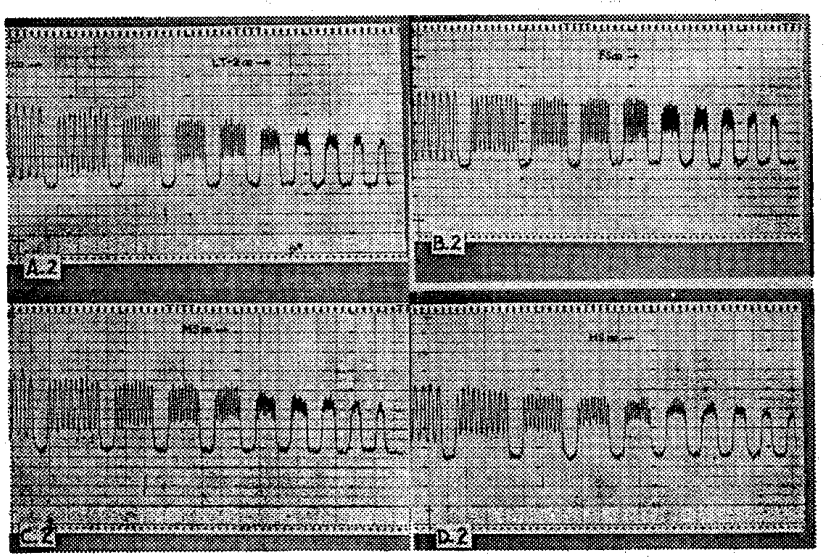

Fig. 20. 


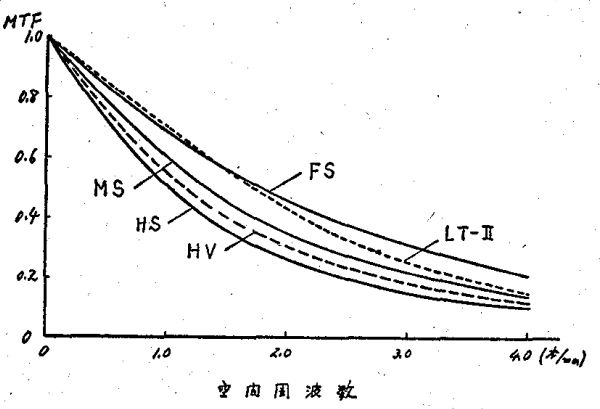

Fig. 21. 各種増感紙の MTF

$0.5 \mathrm{~mm}$ 迄の 10 種類で 使用増感紙は現在胸部撮影に最も 一般的とされている FS, LT-2，HVの 3 種で，F. F. D. $150 \mathrm{~cm}$ ，照射野 $30 \times 40 \mathrm{~cm}$ で素地黑化度は $0.7 \sim 1.0$ の 簌囲内にあるようにした：撮影結果は複数の技師が肉眼 的に判定した。判定方法は全員が弁別可能な時は(十), 一人でも異議のある場合は (土)，その他(一)である。

5-4 増感紙による識別 増感紙による示現は種々の実 験法を通じ HV が最も悪く，LT-2 と FSでは僅かにFS が良い傾向である。

5-5 チャート，フィルム間距離と焦点による識別 使 用焦点は $1 \mathrm{~mm}$ 乙 $2 \mathrm{~mm}$ で，細線チャート 2 個を使用し， 取枠に密着したものと，10 cm 離したもので实験使用 した写真の一例之, 判定結果は Fig. 22 である. チャー

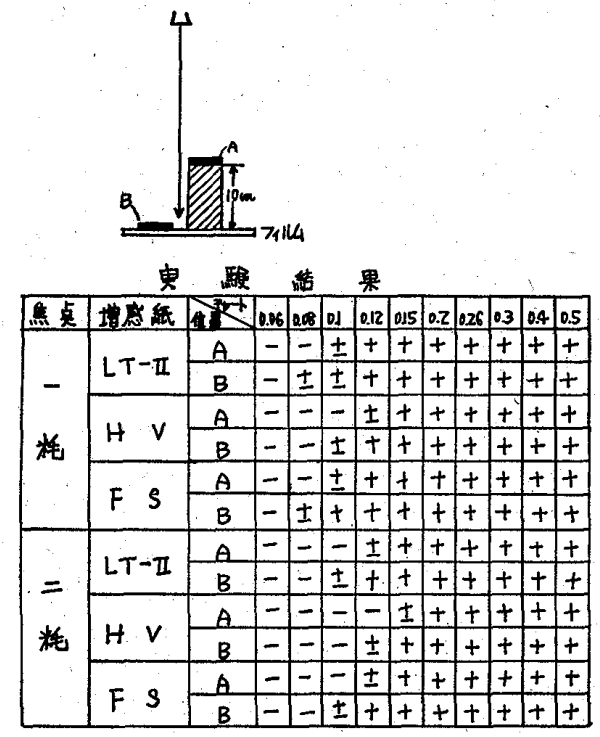

Fig. 22.

ト,フィルム間距離 $\mathrm{A}$ 点では FS, LT-2 共に $1 \mathrm{~mm}$ 焦点 で $0.12 \mathrm{~mm}, \mathrm{HV}$ は $0.15 \mathrm{~mm}, 2 \mathrm{~mm}$ 焦点ではFS, LT-2 共に0.15で HVは 0.2である，而し FSの場合 $1 \mathrm{~mm}$ 焦 点でB点において0.1であるのに対し，LT-2は（土）で ある、したがって FS とLT-2では僅かにFS がよいが，
その差は非常に僅少である、又焦点による示現の差は明 白でチャート・フィルム間距離によって示現は異なって いる.

5-6 角度による識別 細線チャートがフィルムに対し て傾斜した場合示現はどのように変化するかについての 実験で，Fig. 23 は角度 $15^{\circ}$ における判定結果で,チャ一 トのおき方による差は焦点 $1 \mathrm{~mm}$ では比較的少なく，焦 点 $2 \mathrm{~mm}$ では差が出る.而し FSとLT-2ではその差は 比較的少ない. 更に $45^{\circ}$ ではFig. 24 のようにチャート の拉き方によっても，焦点によっても示現の低下は著し い:したがって脍部撮影時の体位と病巣との関係につい て充分に配慮の必要がある。
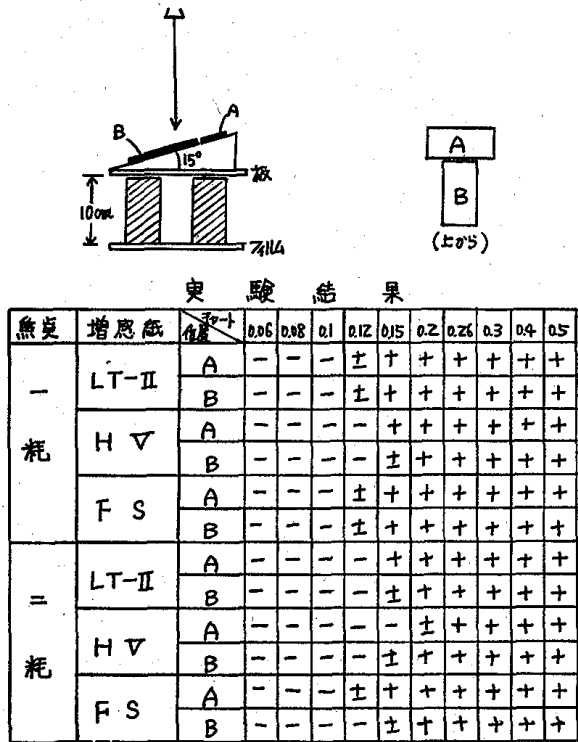

Fig. 23.
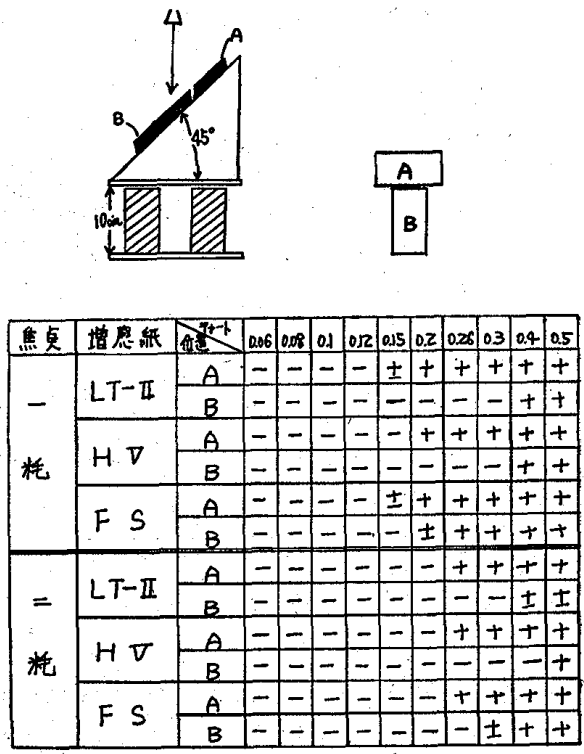

Fig. 24. 


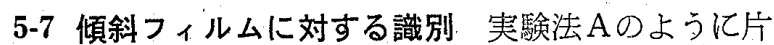
方のチャ一トを一定位置に固定し, Bチャートを密着し てフィルムの角度をかえた実験結果が Fig. 25 でこの結 果からは焦点 $0.3 \mathrm{~mm}$ に和いては $15^{\circ}$ では增感紙による 示現の差は認めないが， $1.5 \mathrm{~mm}$ 焦点においては差が明 白でこの場合，チャート・フィルム間距離の大きい方が 示現は悪い, 次に $30^{\circ}$ にした場合は Fig. 26 で $0.3 \mathrm{~mm}$ 焦点では増感紙による差は少なく，1.5 mm ではかなり 示現の悪化である. $45^{\circ}$ の穾験結果はFig. 27 で0.3 mm 焦点はここで HV とFS，LT-2 との差が認められるがそ の差も比較的少ない. 焦点 $1.5 \mathrm{~mm}$ においては $30^{\circ}$. 亿比 し $45^{\circ}$ は比較的示現は鱼くならない.乙れはチャートフ ィルム間距離が小さくなった為と考える.
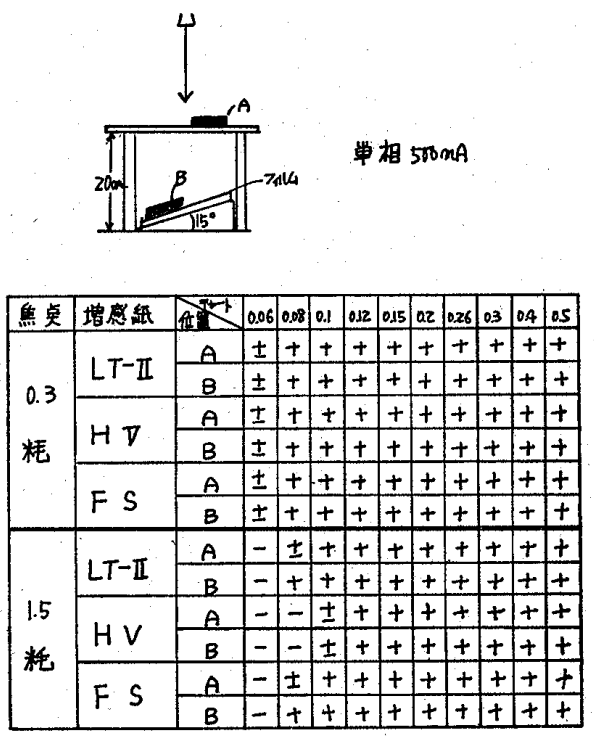

Fig. 25.
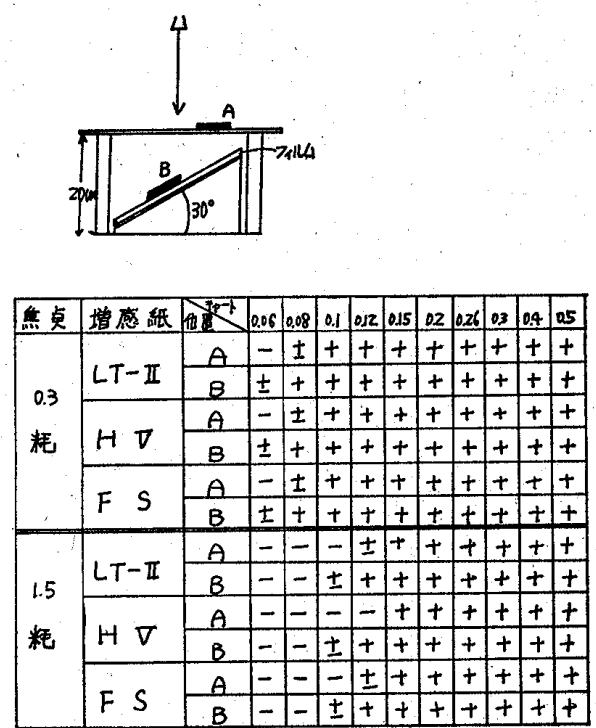

Fig. 26.
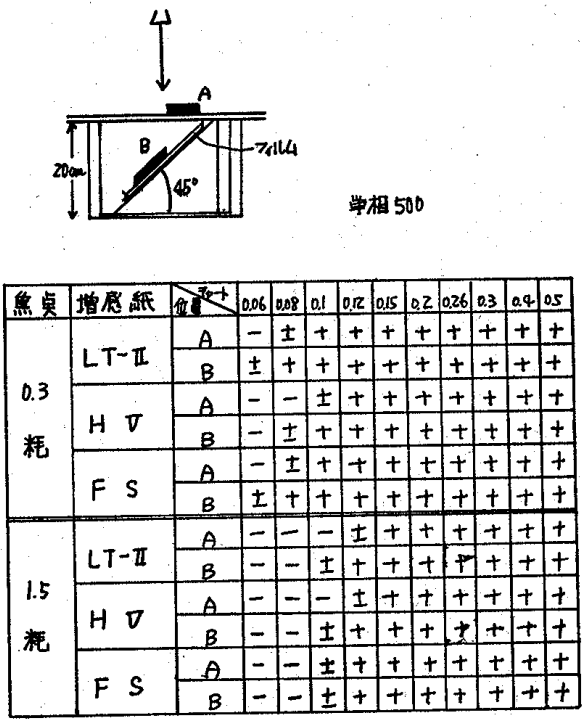

Fig. 27.

5-8 入射角度による識別 チャートとフィルムを平行 注定し入射角度 のみ $15^{\circ}, 30^{\circ}, 45^{\circ}$ にした実験では

Fig. 28 のように $15^{\circ}$ で $0.15,30^{\circ}$ で $0.2,45^{\circ}$ で $0.3 の$ 示現であった。

5-9 小括 以上 ファントムを使用 しない細線法によ る実験結果を考察 するに

1.チャートと

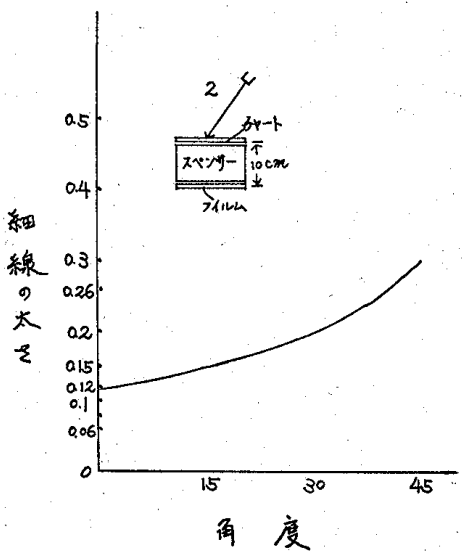

Fig. 28. 角度の示現
フィルム間距離によって示現は異なる。

2. 焦点の大きさにより示現の差は大きい.

3. 3 種の増感紙の中, HV の示現が罗も悪い。

4.FS LLT-2 は僅かに FS が有利である。

5 、傾斜角度は $30^{\circ}$ を越すと示現は著明に悪くなる。

6. 焦点 $0.3 \mathrm{~mm}$ 未満では增感紙による示現の影響が 肉眼的に少なくなる傾向にある.

これらの事から小焦点を用いる事によって，主観的に 増感紙間の示現差を比較的小さく出来る効果があるので かなり画質の向上を期待する事が出来る。

\section{6. 胸部写真の粒状性における諸問題}

現像処理後の写真像はこクロンオーダーの三次元的な ランダム分布で構成され，肉眼で観察される心理的粒状 性は，感光材料の感度上昇にともない，画質を悪くする 
因子に関連し易い, 又X線写真の粒状性は近似的には， 次式によってあらわす事が出来, 粒状性は増感紙よりも フィルムの影響の方が大きい事が報告されている。そこ で実際の胸部写真の粒状性について検討を試みた。

$\mathrm{F}$ total $=\mathrm{K}\left(\mathrm{Fx}\right.$-ray $\times \mathrm{R}^{2}$ screen + Fscreen $+\mathrm{FS} \times$

$\mathrm{FK}+\mathrm{Ffilm}$ )

註 $\mathrm{F}=$ Wiener Spectrum, $\mathrm{K}=$ Constant, Rscreen =増感紙の OTF

6-1 粒状性の基礎実験 胸部写真の粒状性を究明する 事を目的として $30 \times 40 \times$ 厚さ $7 \mathrm{~cm}$ の水槽の上に四切大 アルミ階段をのせ $120 \mathrm{kV}, 200 \mathrm{~mA}$ で撮影したフィルム を 2 分割して現像温度のみ $29^{\circ} \mathrm{C}$ 己 $32^{\circ} \mathrm{C}$ で 3.5 分の現像を 試みた。この特性を知る為に濃度を測定の上，図にした あのが Fig. 29 でアルミの薄い処つまり高濃度部は差は
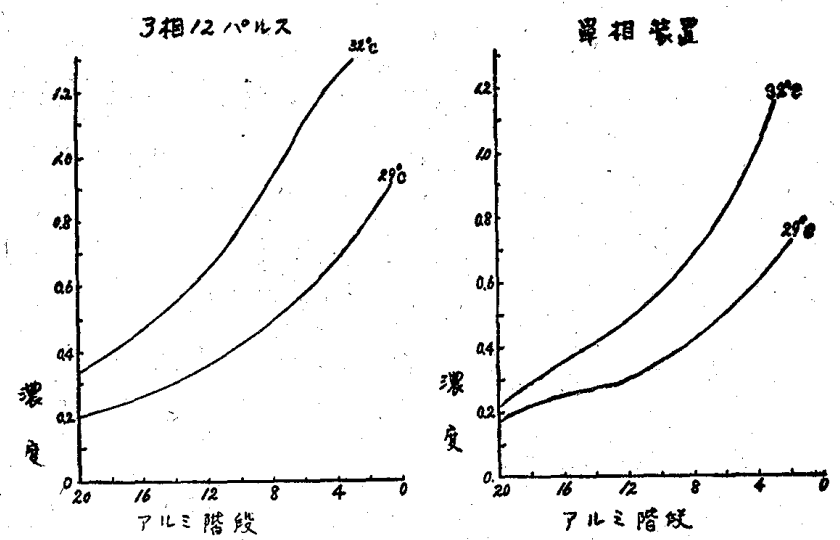

Fig. 29. 現像温度による比較

大きく，低濃度部ではその差は比較的少なくなる傾向に あるが，単相の方が著明である。したがって現像温度が 高くなるとX線写真のガンマは高くなる．しかしその傾

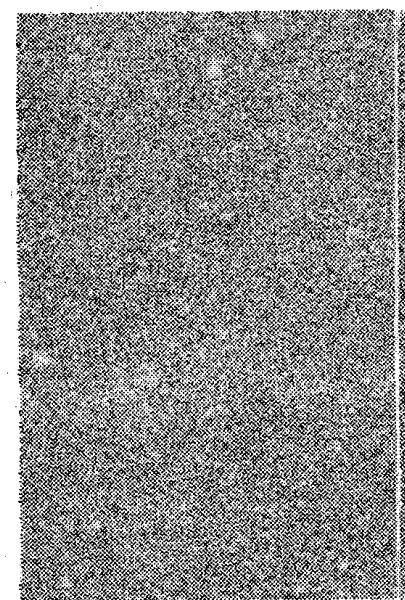

$29^{\circ} \mathrm{C}$

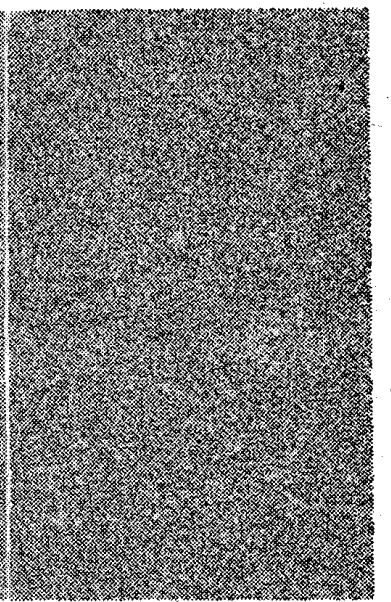

$32^{\circ} \mathrm{C}$
Fig. 30. 現像温度による基礎実験， 3相12パルス（兩面）

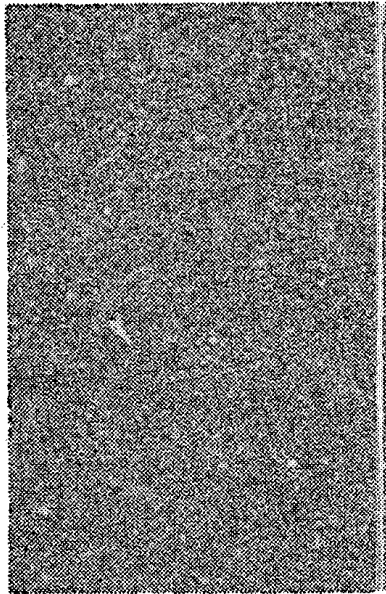

$29^{\circ} \mathrm{C}$

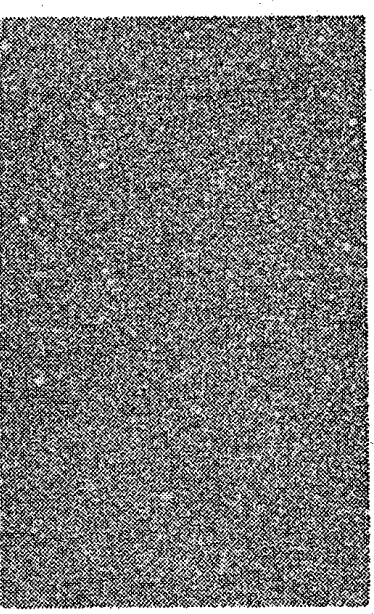

$32^{\circ} \mathrm{C}$
Fig. 31. 現像温度による基礎実験、単相（雨面）

向む3相と単相とでは多少異なり，単相装置で現像温度 の低い場合は，特にガンマはねる傾向が強い。このよう に現像温度によってガンマの異なるつィルムの粒状性に ついて出来得る限り近似した濃度部を 100 倍の桩大写真 で撮影した粒状性を調べると，Fig. 30 が 3 相両膜面の 濃度0.34の場合で，また濃度 0.5 附近の片膜面の場合に ついても求めたが，共に現像温度の高い方が粒状性は悪 い. 又単相装置においては Fig. 31 が濃度 0.25 附近の両 膜面の場合であるが，3相装置に比較して一段と粒状性 は悪くなる，特に現像温度の高い場合は著明である。又 使用フィルムはコダックのB B で指定現像液，3.5分現 像で処理したあのである.

6-2 小括 粒状性の基礎実験を小括するに水ファント ムナアルミ階段を使用した実験では，

1. 单相と 3 相装置で撮影した濃度曲線は異なる。

2. 現像温度を上暈した場合 3 相の方が比較的にガン マが均衝して平行的に上开する。

3. 単相の方が現像湍度が高いとガンマがたってくる 傾问方強い.

4. 粒状性は現像温度の高い方が悪い.

5. 3 相と単相では単相の方が明らが粒状性は悪い。 以上の点から粒状性のよい写真にする為に出来るだけ 現像温度は低くした低ガンマで処理する事が最も得策で， 又X線装置も同じ濃度部においては 3 相装置よりす単相 装置の方が粒状性は鲶い。乙れは散乱線の関係によるも のと推測される。

6-3 濃度による粒状性 胸部写真の粒状性は時として 診断に支障をきたす場合がある，そこで万能桩太投影器 を使用して，実際の胸部写真は濃度によってどのように 変化するかを50倍の拡大写真で比較した。その結果は 


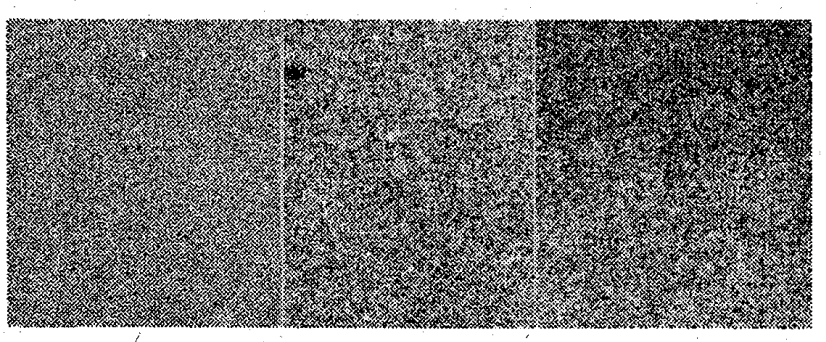

1.17

0.34
Fig. 32. 胸部写真の濃度による粒状性

Fig. 32 で，X線量にも関係するが濃度によってフィル ムの粒状性はかなり買なる。乙の場合低濃度部の粒状性 が強調されると臨床的には粒子あれが目立つ。写真で濃 度 1 以上では粒状性を解明する事は困難であった。而し 0.34末満においては明らかに粒状性は認められた。

6-4 低濃度部の粒状性について 從来肺野の至適最低 濃度といわれていた濃度 0.5 附近について片面の粒状性 を100倍に拡大した写点で観察した. 更に臨床的に粒子 あれの目立つ心臓陰影内の0.25 0.3の濃度について 100 倍の拡大写真で検討を試みた。結果的には同一濃度にお いても粒状性は片膜面の方方并別し易い。

6-5 自現装置による比較 胸部写真の粒状性に自現機 がどのように寄与するかについて同一人を同条件で撮影

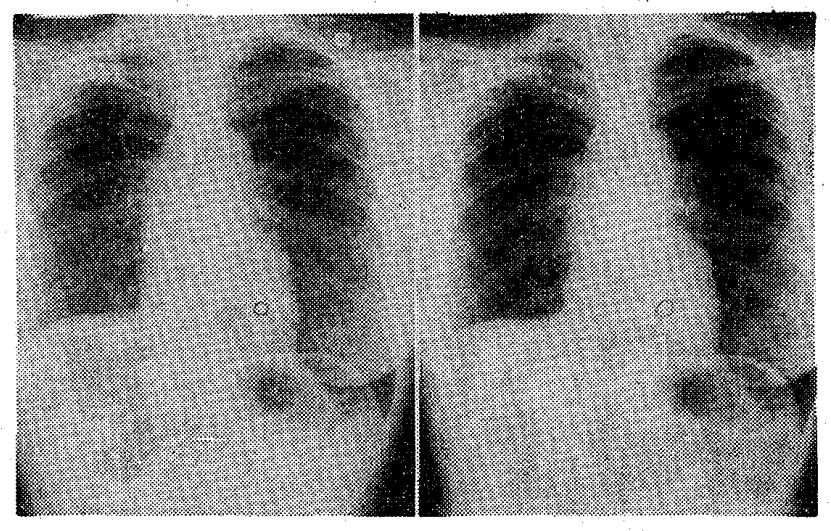
3.5 分 Fig. 33 90 秒

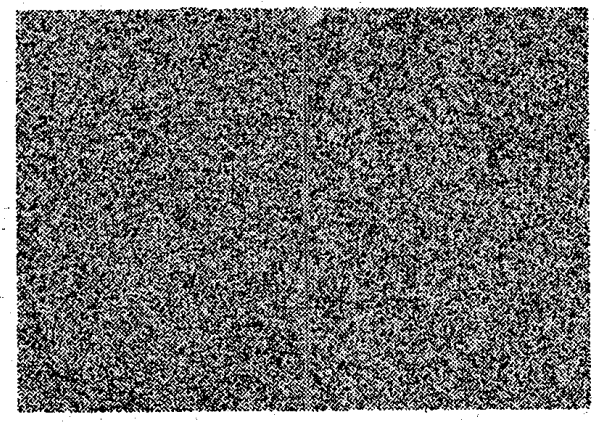

SAKURA 3.5 秒

EK 90秒

Fig. 34. 自現による比較（片面）
した胸部写真を自現機のみ胸部用の 3.5 分と一般用の90 秒で現像処理後, 胸部写真の濃度 0.5 附近の片面を剝し, 100 倍の拡大写真で粒状性を比較した。 その胸部写真が Fig. 33 で写真濃度としては90秒 現像の方が遙かに濃度 も高く過度現像の写真である．その拡大写真が Fig. 34 で90秒処理の方が粒状性は強調され易い. 又心臓陰影内 における粒状性についても調べてみたが同じ傾向である.

6-6 X線装置による比較 単相と 3 相 12 パルス装置は 従来 3 相の胸部写真が鮮明で単相が多少劣る事が指適さ れていた。 そこで粒状性を比較する為に同一被写体を可 能な限り近似的な濃度になるような条件で撮影したフィ ルムを同一自現機で妈理の上, $0.25 \sim 0.30$ 濃度を 100 倍 の拡大写真にしたが，両装置の粒状性は肉眼的には弁別 困難であった.又0.5附近の片面の拡大写真では 3 相の方 が僅か乍ら粒状性は良い。乙れは基礎実験と一致してお り散乱線による影響と考えられるが尚検討の必要がある.

6.7 フィルムによる比較 同一増感紙でフィルムのみ 国産 A，B社の比較を行なったが粒状性は異なり，B社 のフィルムの方が粒状性は悪い.

6-8 感光材料の組合せによる比較 同一フィルムで増 感紙のみ, FS とLT-2亿交換して単相装置で撮影した粒 状性の比較を行なったが明らかにLT-2 との組合せの方 が粒状性は悪い.又 3 相装置での比較む行なったが結果 は同じ傾向である．乙の場合現像温度との関係が特に強 ():

6-9 小括 胸部写真の粒状性は濃度によって異なり， 低濃度部が強調されると臨床的に粒子あれの目立つ写真 になる. そとでとれ等の実験結果について小括してみる 亡,

1.自現装犆によって，特に90秒では臨床的に粒状性 は強調され易い。

2. 単相と 3 相では臨床的にも 3 相の方が粒状性はよ (.

3. 増感紙とフィルムの組合せによって粒状性は異な る.この場合フィルムの影響が大きい.

4.FSとLT-2ではLT-2の方が粒状性は悪い.

5. 現像温度を下げる事によって粒状性を良くする事 ができる。

以上の結果から粒状性の良い䏩部写真を得る為には出 来るだけ低い現像温度で処理する事が現状においては最 も適切で特に90秒で現像する場合においては重要である.

\section{7. 散乱線除去に対する諸問題}

胸部撮影におけるグリッドの使用方法は静止法と移動 
法とがあり，前者はグリッドのしま目が読影仁影響する 場合もあるので一般的にはグリッドを移動して使用する 事がのぞましい。

との代表的な方法 としてカタパルト 式, レシプロ式, 直線式とが利用さ れているが実際に は胸部の場合アン ケートでも明白な 上うに0.1秒以内 の撮影時間である 為, ごの方式を利 用してあ直線式と 殆んど変化はない。

Fig. 35 はレシプ

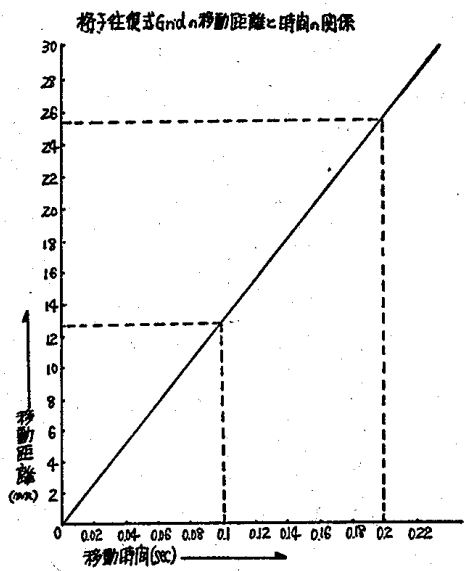

Fig. 35. 格子往復式グリッドの 移動距離之時間の関係
口機構の運動時間を図に示したものである。

7-1 グリッド濃度斑について，近年グリッドの製作技 術は上昇し殆んど濃度斑等は解消されているが高密度グ リッド等はスペーサーの関係等から時に濃度斑をみる事 ああるがこ等は撮影時間中に略々濃度むらの 3 倍以上 グリッドが移動しておれば実用上濃度斑は支障がない.

Fig. 36 は著明なグリッド濃度斑であるが移動する事に よって殆んど支障はない。

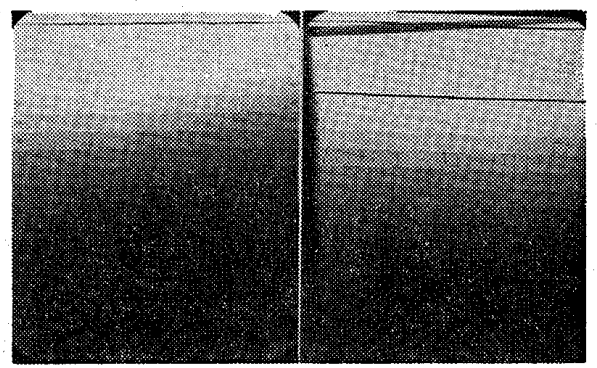

静止
Fig. 36. グリッド濃度斑

$7-2$ 散乱線含有率について 被写体透過後の X線による散乱線含有率についてはすでに多数 の測定結果が報告されているが，てれらの報告 には 3 相と単相の比較についての報告は比䡥的 少ない。そこで次の方法により散乱線含有率を 測定の上比較した。

\section{7-3 実験装置並びに条件}

X線装置 東芝 KXO-1000 3 相12パルス装置 日立 DRX-155A 単相 500iMA 型 測 定 器 マッキ螢光量計 ファントム 水 $30 \times 40 \times 10 \mathrm{~cm}$

測定距離 $150 \mathrm{~cm}$

測定電庄 $60,80,100,120,140 \mathrm{kV}$

照射野 $30 \times 40 \mathrm{~cm}$

ブッキ装置 東芝直線式

グリッド 三由屋 MS, 40本/cm, 6: 1, 8: 1, $10: 1,12: 1,15: 1$

7-4 実験方法 散乱線の測定方法には線量計法：フィ ルム黒化法, 營光量法等があるが線量計法は線質, 方向 依存性等があり，フィルム法等においては可成り手数が
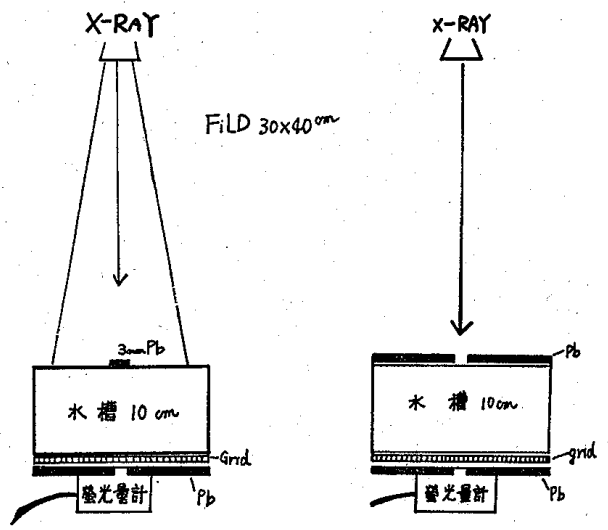

Fig. 37. 散乱線測定法

かかるので螢光量法によ り Fig. 37 の測定法によ って実験をおてなった。 実験に使用したブッキー 台は Fig. 38 で実施に当 っては，多重絞り（以下 普通フィルタと略す）と 附加フィルタのある場合 の比較実験をおこなっ た。

7-5 測定結果 普通フ

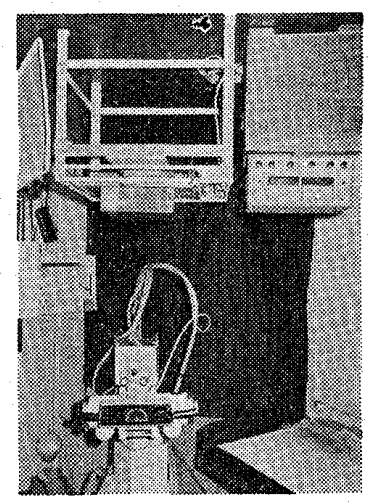

Fig. 38.グリッド実験装置

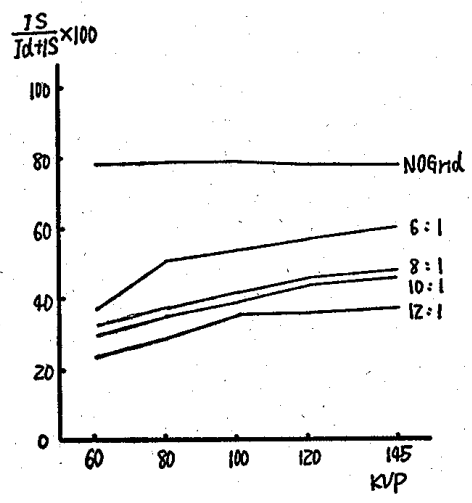

Fig. 39. 散乱線含有率 （単相 普通フィルタ）

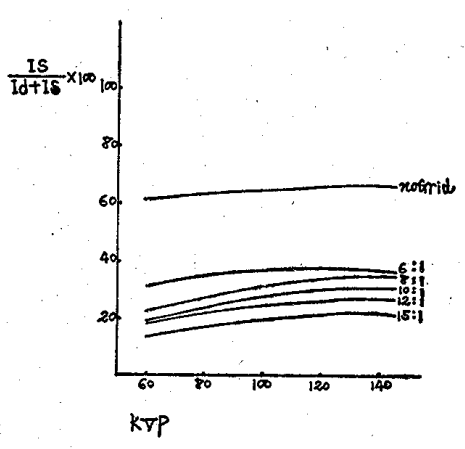

Fig. 40. 散乱線含有率 $\left(\begin{array}{l}3 \text { 相, } 12 \text { パルス， } \\ \text { 普通フィルタ }\end{array}\right)$ 
ィルタによる測定結果は Fig.39 が単相装置で Fig. 40が 3 相12パルス装置であるが, 単相と 3 相ではかなりの散 乱線含有率に差があり，単相の方が散乱線含有率は高い。 したがって同じ散乱線量にする為には $100 \mathrm{kV}$ から 120 $\mathrm{kV}$ で 3 相 6:1 亿対し単相では12:1 のグリッドが必要 で臨床的には 3 相装置の方が有利である.

7-6 付加フィルタによる影響 イ） $2 \mathrm{~mm}$ アルミ板に ついて 普通フィルタの上にアルミフィルタを附加し た場合によ゙のように散乱線含有率が変化するかについて

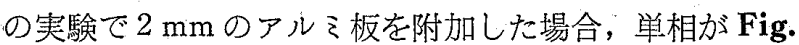
41 で, 3 相が Fig. 42で, 普通フィルタに比し散乱線含

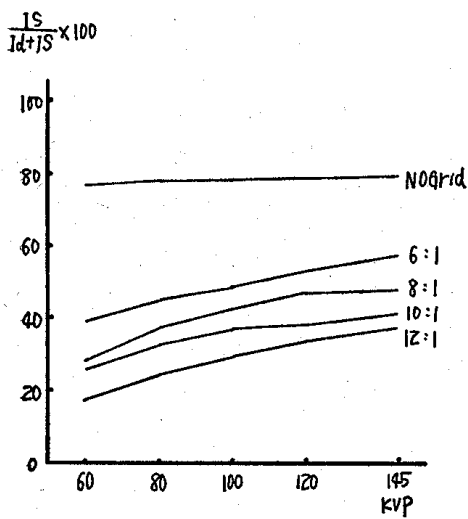

Fig. 41. 散乱線含有率

(単相, 普通 $+\mathrm{Al} 2 \mathrm{~mm}$ )

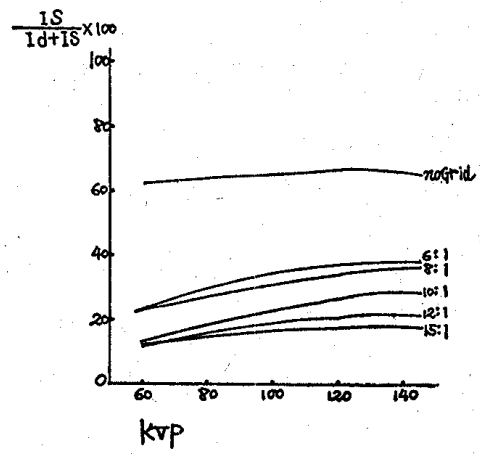

Fig. 42. 散乱線含有率

（三相，12パルス，Al $2 \mathrm{~mm}$ 附加）

有率はかなり減少する事が特徵である．特に単相の場合 にその傾向は強い.したがって $2 \mathrm{~mm}$ 程度のアルミ附加 は是非使用したい.

ロ ) $0.2 \mathrm{~mm}$ 銅 $+2 \mathrm{~mm}$ アル之板について 単相にお いて銅とアルミの附加フィルタの場合はFig. 43 で普通 フィルタ使用時に比較してかなりの散乱線含有率増加で ある. 又 3 相 12 パルス装犆の測定結果は Fig. 44 である が 3 相は，No.グリッドの場合は増加であるがグリッド 使用の時は電圧の低い側でむしろ減少の傾向である。し

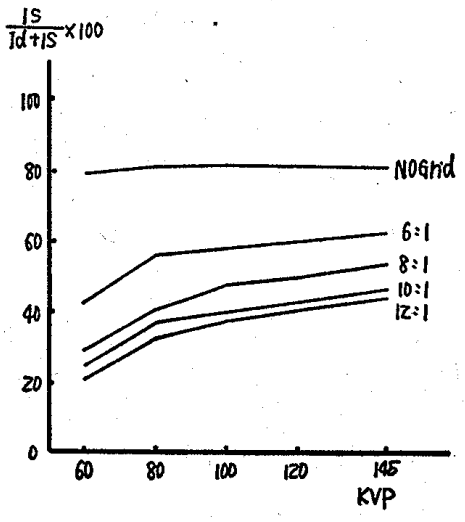

Fig. 43. 散乱線含有率 (単相, 普通 $+\mathrm{Cu} 0.2 \mathrm{~mm}+\mathrm{Al} 2 \mathrm{~mm}$ )

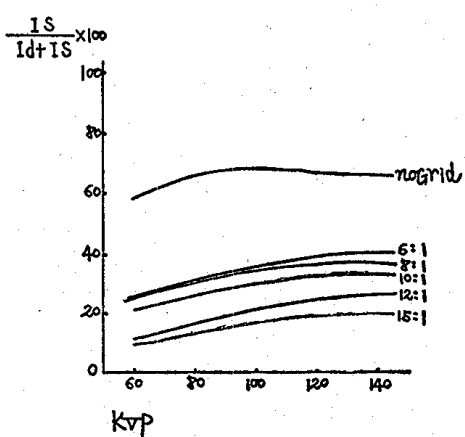

Fig. 44. 散乱線含有率 (三相, 12 パルス $\mathrm{Cu} 0.2 \mathrm{~mm}$ )
かし $100 \mathrm{kV}$ 以上で10: 1 未満では散乱線含有率の増加 である、ての実験から不注意なフィルタの增加はむしろ 散乱線含有率を增加させる事を考慮すべきで特隹相装 置はその傾向は強く使用する場合にはアルミの方が一般 的溹有利と考える.

八）附加フィルターの厚い場合 参考までに附加フィ ルターを厚くして実用範国をてえた場合散乱線含有率が どのようになるかについて単相装置により比較実験を試 みると Fig.41(A)(B) のような結果になり，AとBでは フィルターの厚い $\mathrm{B} の$ 方が散乱線含有率は高い.

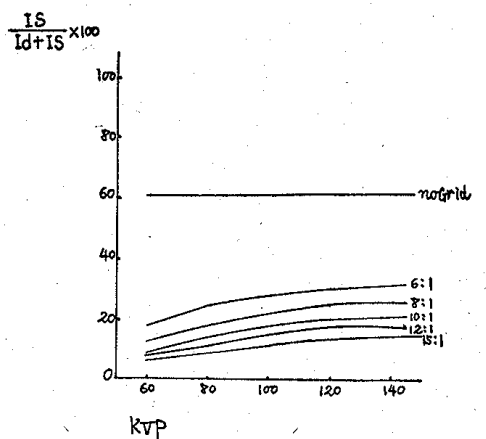

Fig. 45(A). 散乱線含有率の実験 単相 $($ 普通 $\mathrm{Al} 0.5 \mathrm{~mm}$ 相当 $)+\mathrm{Cu} 0.2 \mathrm{~mm})$
$+\mathrm{Al} 0.5 \mathrm{~mm}+\mathrm{Al} 2 \mathrm{~mm}$

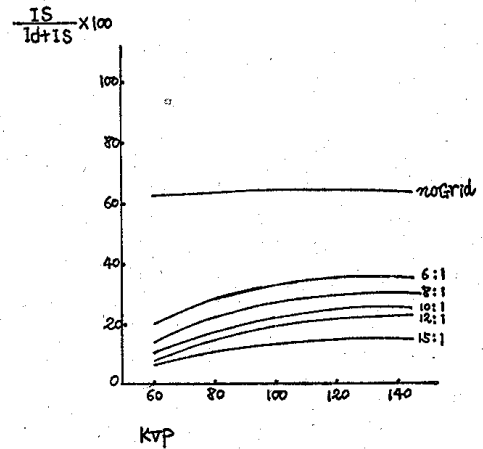

Fig. 45(B). 散乱線含有率試験 $\left.\begin{array}{l}\text { 単相, 普通 }(\mathrm{Al} 0.5 \mathrm{~mm} \text { 相当 })+\mathrm{Cu} 0.2 \mathrm{~mm} \\ +\mathrm{Al} 2 \mathrm{~mm}+\mathrm{Cu} 0.2 \mathrm{~mm}+\mathrm{A} 10.5 \mathrm{~mm}\end{array}\right)$

$7-7$ 考察 以上の点を考察すると散乱線 含有率はグリッドの材質とフィルタとの因 果関係が推測出来るので適正なフィルタを 使用しないと散乱線含有率の減少にはなら ない.との事汃ら胸部用の附加フィルタと してはアルミを使用した方が一般的に有利 である，参考までに異常に厚い附加フィル 夕を使用した場合です厚いフィルタの方が 散乱線含有率が高いので, フィルタの増加 は時により散乱線含有率の増加につながる 
事を銘記すべきである。

7-8 グリッドの使用露出倍数 螢光量の測定值汃グり ッドを使用した場合とNoグリッドの場合を比較してダ リッドの使用露出倍数を図にしたのが Fig.46で単相装 置の方がはるかに使用倍率は高く, 又使用倍率は電圧の 高い程低い。

\section{Grid 箈出倍数 (鉴相，普通)}
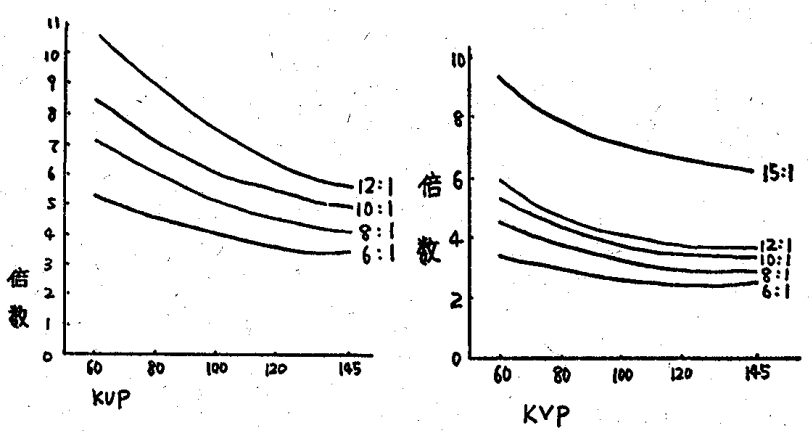

Fig. 46.

フィルタによる使用倍率 銅 $0.2 \mathrm{~mm}+$ アルミ $2 \mathrm{~mm}$ フィルタ付加の場合の使用露出倍数は Fig. 47 で，単相 では普通フィルタに比しかなりの倍数の減少である。乙 れは線質によるグリッドの透過率に起因するあのと考え ます。

Grid 露出借数

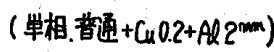
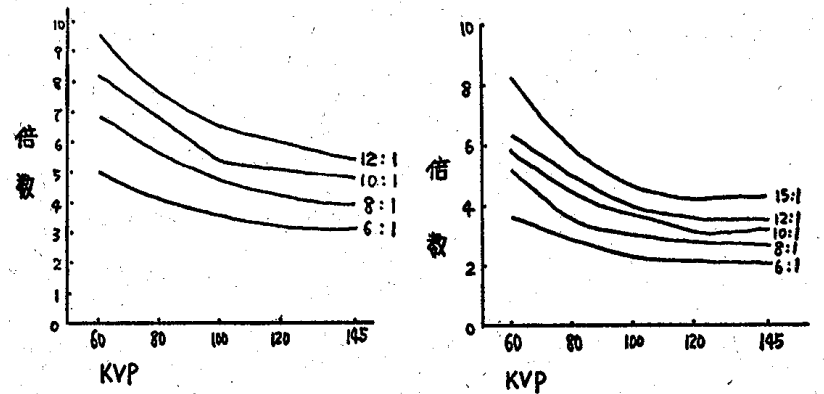

Fig. 47.

7-9 立証実験 3 相装置による露出倍数確認の為，同 一被写体を使用し管電圧, 管電流は同じで時間だけかえ て撮影した写真が Fig. 48 で略々濃度的には実験の通り である。

7-10 グリッド密度による比較 同一メーカーの製品 で密度のみ異なる格子比 $6: 1$ のグリッドについて比較し てみると Fig. 49 のように散乱線含有率は単相の場合34

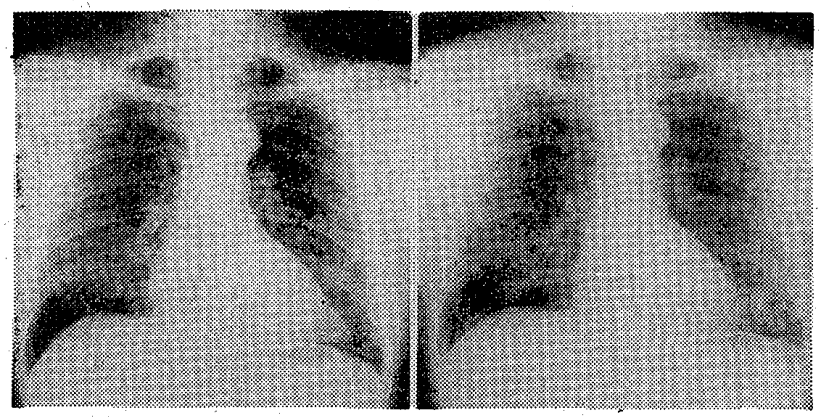

グリッド(十)10:1

グリッド(一)

Fig. 48.

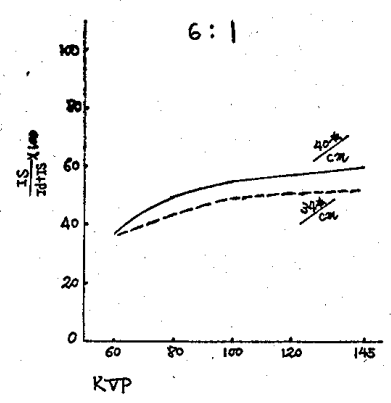

（单相普通）

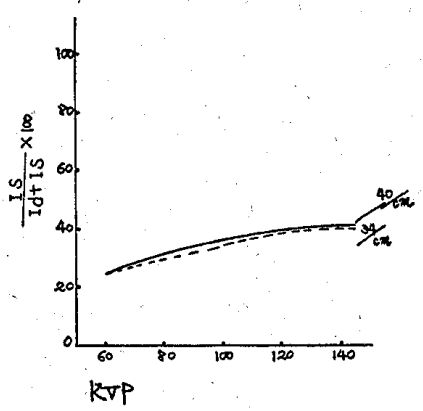

（三相，12パルス普通）
Fig. 49. 散乱線含有率の比較

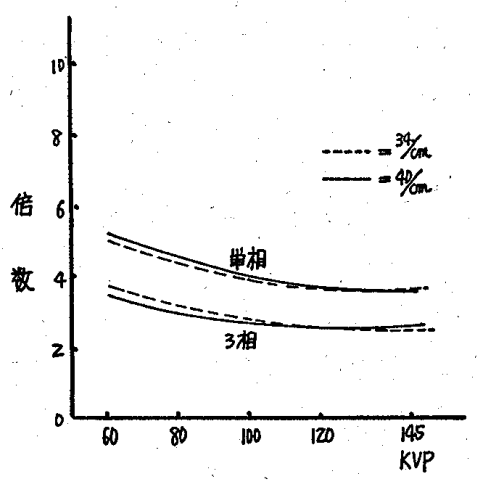

Fig. 50. グリッド倍数の比較 $6: 1$ (普通)

本/cmの方が少ない，而し静止法においてはその差は殆 んどない. 又グリッド使用露出倍数は Fig. 50 で40本と 34本では有意差は殆んどない.

7-11 小括 以上実験の結果について小括してみると 次の如くなる.

1. 3 相に比較して単相の方が散乱線含有率は高い. したがって同一散乱線含有率にする為には $100 \mathrm{kV}$ で 3 相 6:1 亿刘し単相 12:1 が必要である.

2. 附加フィル夕の影響は単相の方が大きく $2 \mathrm{~mm} の$ アルミ板では散乱線含有率は減少し, 銅 $0.2+$ アルミ 2 $\mathrm{mm}$ では増加である:

3. 3 相の場合附加フィルターによる散乱線含有率は アルミ $2 \mathrm{~mm}$ では減少であるが, 銅フィルタの場合 No 
グリッドでは増加である.

4・グリッドの使用倍数は 3 相よりも笚相の方が大き い.

5. 使用倍数は管電圧の高い方が小さくなる。

6. 6: 10格子比の場合 34 本 $/ \mathrm{cm}$ の方が散乱線含有 率は少ない。而し静止法ではその差は殆んどない。

7. 密度34本と40本では使用倍数の違いは殆んどない.

8. 一般的に附加フィルタの㕌い方が散乱線含有率は 高くなる。

\section{8. 気管支造影法における諸問題}

気管支造影剂は㭧者の副作用がない事が前提で造影剂 の注入法は执よそTable.6のように区别できる。特に選

Table. 6 注 入 法
1. 声閒上注入法
2. 甲状輪状鞋带穿刺法
3. 気管内カテーテル法
4. 気管支鏡によるカテーテル注入法
5. 選択的気管造影法（メトラ氏法） *䛵飲法

択的気管支造影法が非結核性の鑑別に利用される事が多 くなった。この注入法は目的気管支から順次䧓国の気管 支に造影剤を注入して引く方法で全体としてはかなり多 量の造影剤を必要とし，加えて注入された造影郕が䏽胞 まで流入されないるのが良好である。しかし萢管支造影 荗む最近では希望の造影剂が入手困難になって来ている のが現状である。

8-1 造影㧩の粘着力について 造影剤粘着力の笑験方 法としてフフィルム゙ース上に 3 種の造影剤を 1 滴ずつ

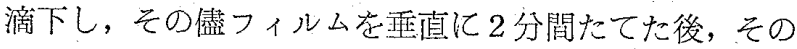

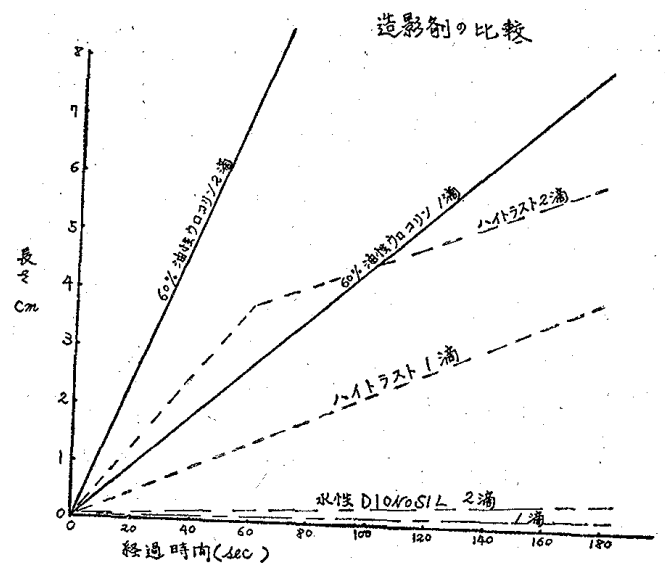

Fig。 51. 造影殽の比較

長さを計測した・その結果ディオノデールは㫊んど動い ていない事が特徽である。次に 2 滴ずつ滴下した同じ実 験でその結果を表にしたのが Fig. 51 であるが，ディオ ノヂールが最も流れにくく，続いてハイトラスト，油性 ウロコリンの順である. 更に造影剂 $1 \mathrm{ml}$ について同じ 実験を試みた。そノ結果, 長さ $27 \mathrm{~cm}$ を流れる時間は油 性ウロコリン（2条）15秒，ハイトラスト30秒，40\%モ リヨドール130秒, ディオノデール14 cm/180秒.ディオ ノヂールは 3 分経過後に执いても僅かに $14 \mathrm{~cm}$ 流れた のみで非常に動きにくい造影剤である．乙の為選択的順 次分割注入法に好都合である。而しカテーテル法の場合 には目的気管支に到達するのに時間のかかる事も留意す る必要がある。

8.2 造影効果の比較 造影効果を比較する為に，水フ

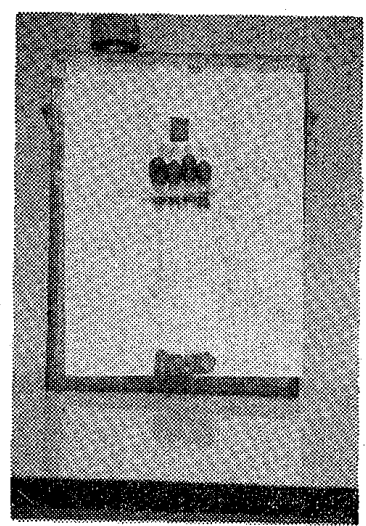

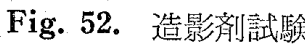

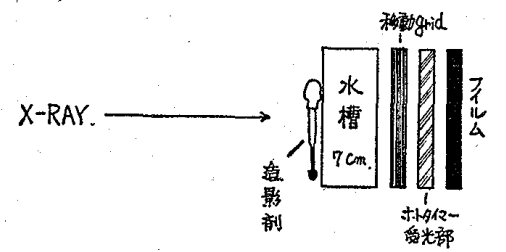

Fig. 53. 造影剤の試験法

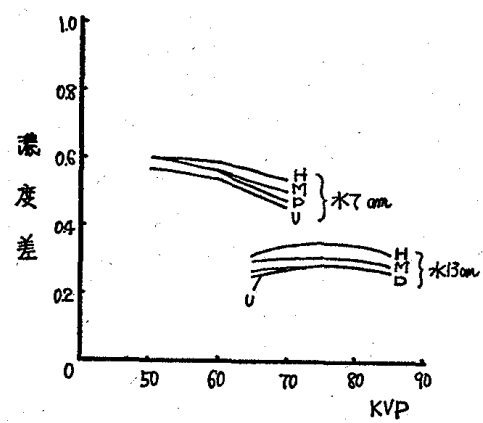

Fig. 54. 造影剤の比較 (グリッド(一)フィルター普通) $\mathrm{H}$ ハイトラスト， $\mathrm{M}=$ リヨドー ル, $\mathrm{D}=$ ディオノヂール, $\mathrm{U}=$ 油性 ウロコリン
アントームを用い 試験用ピペットに 造影剤を注入して 実駼を試みた。ピ ペットは細かい部 分が $15 \mathrm{~mm}$ ，太い 部分が $5 \mathrm{~mm}$ の内 径で Fig 52 の通 りである。笑験方 法は, Fig. 53 で 撮影方法注出来得 る限り線舅を一定 にする為にホトタ イマーによる線量 制御法を用い, 撮 影結果はピペット の内径 $5 \mathrm{~mm}$ に相 当する造影剠部分 と水ファントーム 部分の濃度測定を 実施して, 水ファ ントム濃度と造影 剂濃度の差を求め て比較した。その 結果が Fig. 54 で グリッドなしの場 合には散乱線の影 㗽によりかなり濃 度差は少ない。次 亿水 $7 \mathrm{~cm}\llcorner 13 \mathrm{~cm}$ 
を比較すると更に差は少なくなる。したがって対比度の 悪い写真となる. 又造影効果は良い方からハイトラス ト，40\%モルヨドール，ディオノデール，ウロコリンの 順である。次にグリッドを使用した同じ実験結果は Fig. 55で各造影剤間の濃度差は一段之明確になるが升別度は

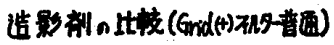

水 7 的
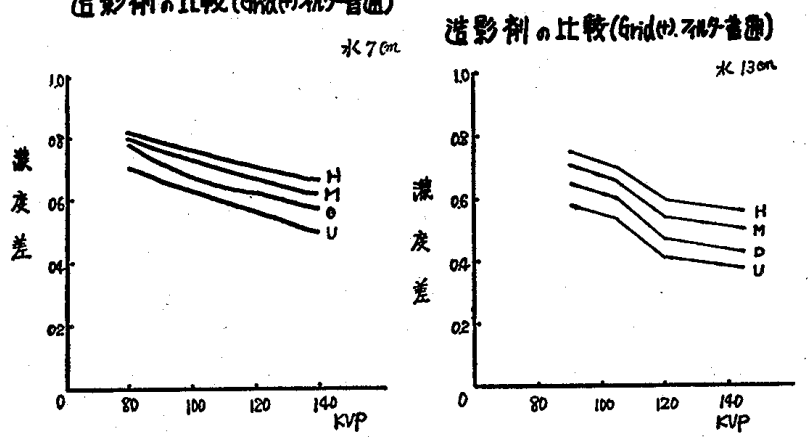

Fig. 55. 水槽による比較

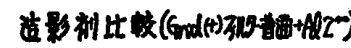
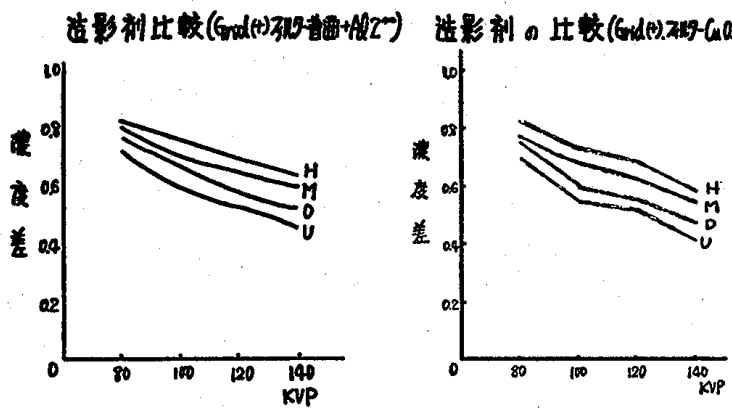

Fig. 56. フィルタの比較

水の厚さによって異なる，又管電压を上昇してす，グリ ッドなしに比較しかなりの対比度の上昇である。てて結 果加ら造影剤它使用した場合管電圧の上昇による対比度 の悪化よりも散乱線の影響の方が大きい. 又フィルタに よる影響は Fig. 56 でフィルタの厚さが厚い程造影効果 は悪くなる傾向にある，乙の実験加ら臨床的に明膫な気 管支像を得る為にはまず散乱線の除去を充分になす事が 重要である。

8-3 小括 以上造影剤について小括すると，

1. 造影剤の粘着力はかなりの相違がある.

2. 注入方法によって造影剂の選択が必要である.

3. 造影剂の種類によって造影効果は異なる.

4. 被写体の厚さによって造影効果は異なる.

5.グリッド使用によって対比度は向上する.

6. 散乱線の影響が造影効果を思くする要因となる.

7.グリッドを使用する事により管電圧を上昇しても 実用上支障はない。

\section{3 相12パルス装置における諸問題}

X線装置の高生化にとむない単相装置においては夕イ マー回路は 0 位相で開閉し異常電圧を防止しているのが 3 相装置においては各相が $2 / 3 \pi$ の位相ズレをもってい るので同時に 0 位相で投入するととは困難である.との 為 2 次側制御が理想であるが，一部の装置を除き一次側 による制御が多く用いられ，異常電圧の防止之極短時間 制御 (3/1000)を目的とした二次投入方式が利用されてい る.とれはまず一次投入においては正規電厓の $1 / 2 \sim 1 / 3$ の範囲で投入し写真効果としては $1 / 4$ 以内に最大線量率 をおさえ二次投入をする方式で，写真効果としては正規 電圧の印加時間だけの筈であるが現実にはこれが無視さ れた装置はかなり多いようである。したがって 3 相 12 パ ルス装置については二次側電生波型による調整を義務づ ける必要がある。

9-1 3 相12パルス装置の波型について 3 相12パルス の波型について昭和 46 年 47年に購入した内外の装置に ついて測定をしてみると理論上,リップルは $3.4 \%$ と乍 らも, 投入電圧, 波型率共に問題が多い。 ての測定結果 は次のようになる。

9-2 波型の歪 3 相 12 パルスA装置の波型は据付完了 時に撮影したもので測定方法としては変圧器の二次側ブ ッシングから管球と並列にオイル抵抗器を通して, オッ シログラフにつなぎ二次側波型を記録したあのであるが Fig. 57 のように低圧側においては比較的に波形率もき れいで歪す少ないが管電压の上昇と共佂が大きくなり 時間の経過と共に比較的波形が安定していく装置である. Fig. 58 は高圧側の波型で,胸部撮影に於ては実用上短時

$80 \mathrm{kvp}$
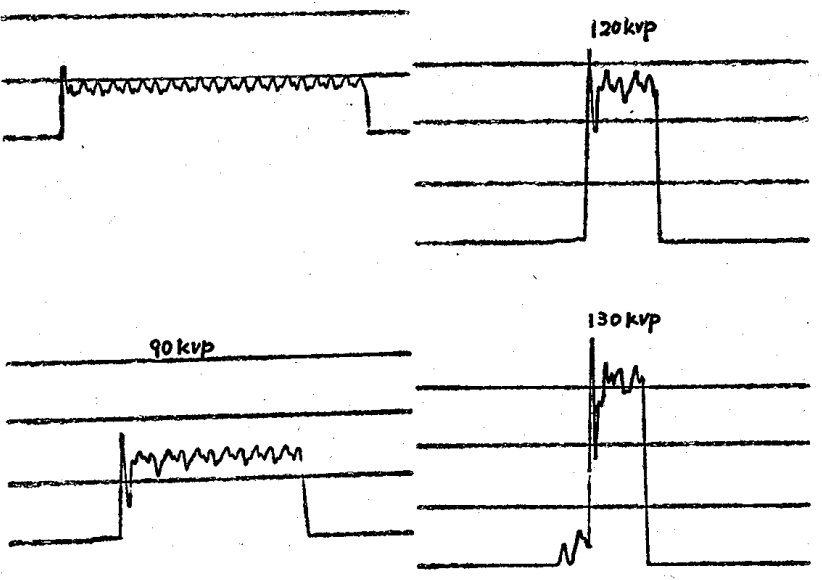

管電圧波形（3 相12パルス）管電圧波形（3 相12パルス） Fig. 57 


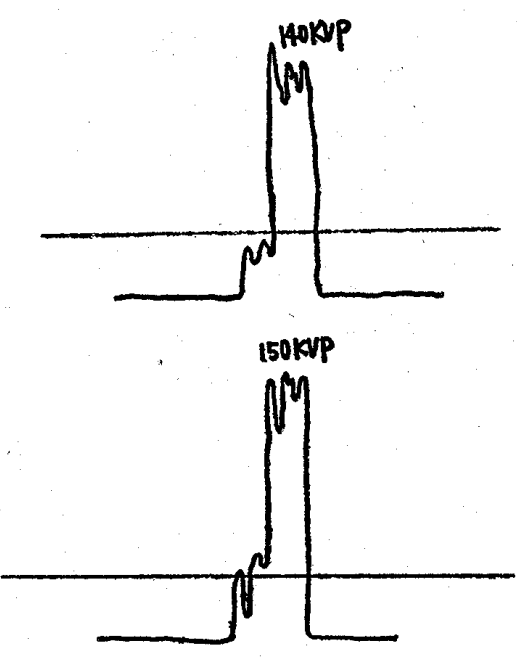

Fig. 58. 管電圧波形（3 相12パルス）

間側が重要でここに問題の少ない装監が理想である。こ の波形の歪は一般的には投入時の異常電圧といわれ，現 在使用中の二次投入方式の多くの装置にこの傾向があり， メーカーに整備させても装置が正規の波形に復畄し難い のが現状である。

9-3 投入電圧の異常 この装置の二次波形は管球容器 内から低降トランスを通して，オッシログラフに接続し て二次波形を測定したもので，据付時の波形は Fig. 5y で管電圧の上昇と共に二次投入点が移動し，管電压が高 くなればなる程投入位置が高くなる装置で，ついには一 次投入と二次投入 位置が接近するケ ースである・との 場合最早や二次投 100MA 8OKVP

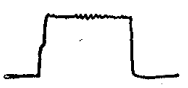

200 MA 80KUP

入の意義はない。

投入電庄とタイマ

調整後の波形が

Fig. 60 であるが

依然として一次投

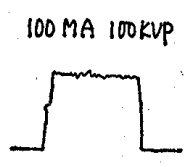

200MA 100KJP

入電压は高い.夕夕 イマによる波形は

Fig. 61 であるが 一次投入時の電圧 が加わるので写真 効果としてはかな りの延長で特に高 王撮影の時一段之 強調される事が推 測出来る、したが
つて装置の据付調 整時の二次波形它 測定する事をメー カに義務づける必 要があり，正期波 形で使用出来るよ う改善すべきであ る.

9-4 写真効果加 らみた投入電圧と タイマの測定法
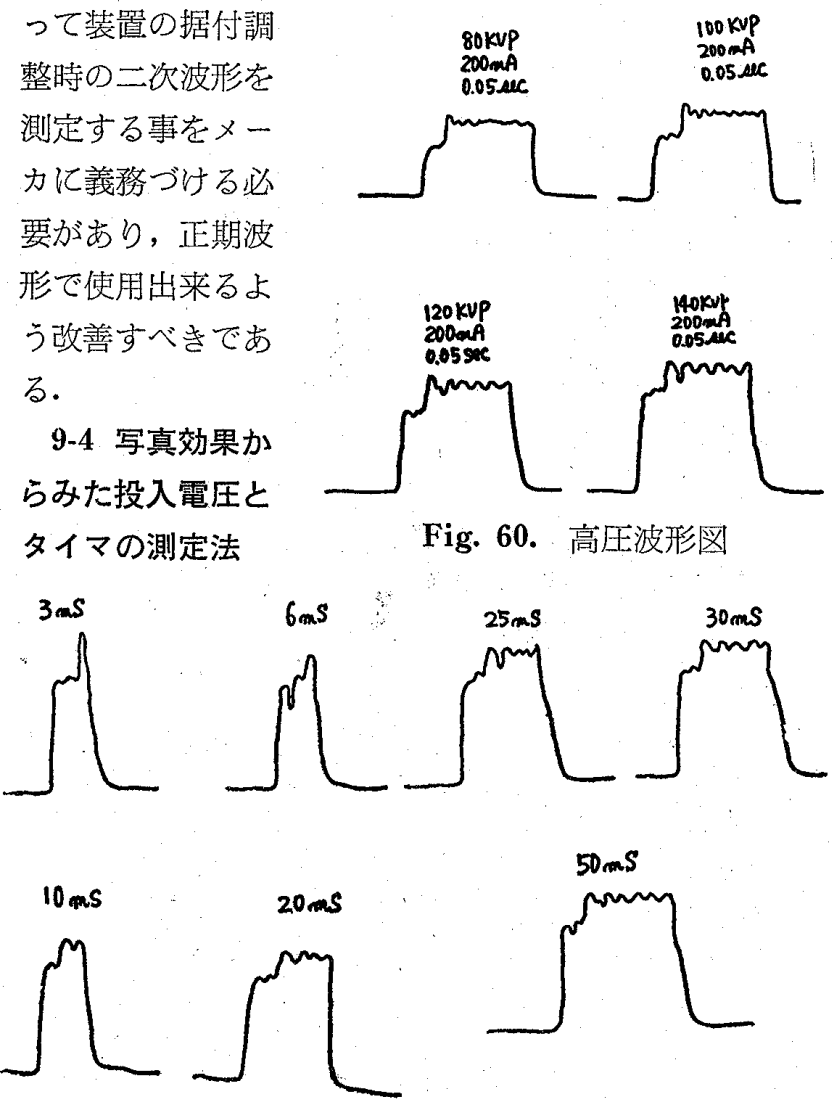

Fig. 61. 高压によるタイマ試験

高圧二次側波形に疑問があり計器がない時は，写真效果 により測定する事も意義のある事で種々検討の結果スト ロボ法を導入する事によって，一次投入電圧とタイマ測 定が出来る事が判明した。測定方法として直線ブッキー 撮影台を利用した垁験でグリッドの移動距離と移動時間 を測定しててれを 利用すれば簡単で， 特に直線式とレシ プロ方式が良好で ある.との場合反 覆測定した平均移 動時間を利用する。 通常0.2 0.3秒程 度である。厚さ 1 〜 $2 \mathrm{~mm}$ の鉛板を 用い, 片側飞切込 みか穴をあけ，こ の部分が移動の先 端になるように取 付计て測定する。 胸部の場合問題が

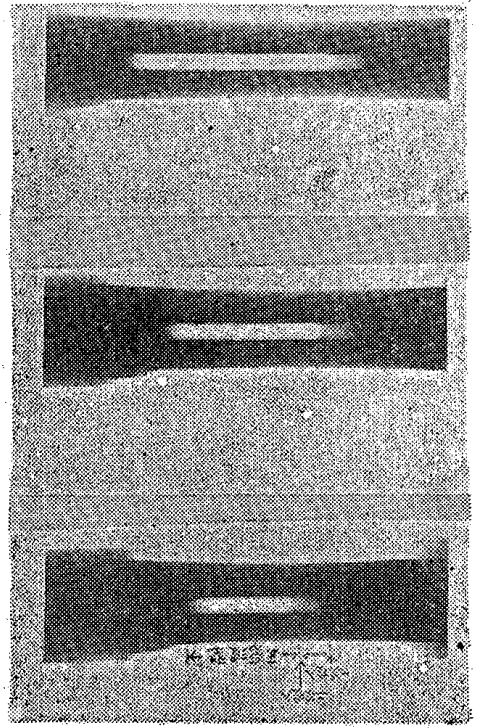

Fig. 62. ストロボ像による 写真効果 
多いのは，撮影時間が短い場合と雪圧が高い場合である。 したがって比較的電压の低い所では意味が少ないので実 際に使用する電流で, 電圧は $80 \mathrm{kV}$ 以上, 測定時間は実 用簌聿内で良い。との方法で撮影したストロボ像が Fig. 62であるが，通常は一次投入位置は確認されないのが良 好な装置で，このように明膫に描写される装犆は非常に 問題のある倸置である.

9-5 タイマの簡易計算法 ストロボ像から有効撮影時 間を算出する尋が可能である。実験の初めにグリッドの 移動距離乙移動時間を測定してあるので

撮影時間 $=\frac{\text { 移動時間 }}{\text { 移動距離 }} \times$ ストボ像の舆さ

で簡粆に算出する事が出来る，又桩大率を配慮すれば尚 正確になる。

9-6 応用法 とのストロボ法を腧部撮影時にX線装置 のチェック法として応用しているが，てれはフィルムの 端に撮影するので確率では少るが，装置の状態を監視す る為には都合が良い。 Fig. 63 はマトロボ法の応用例で 正規像と電源夕ーミナルの緩みによる故障例で，ストロ ボ現象としては洋相波形のストロボ像に似た現象である。 又Fig. 64はホトタイマを使用した場合で X線開閂器の 接片の黑化現像による場合で，電压隆下により薄い胸部

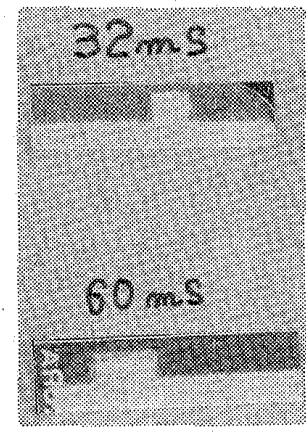

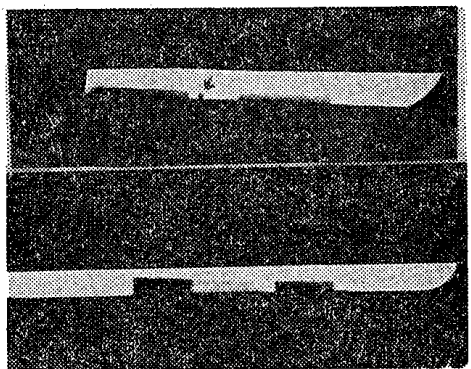

故障例
Fig. 63。三相12パ氏ス・ストロボ儌

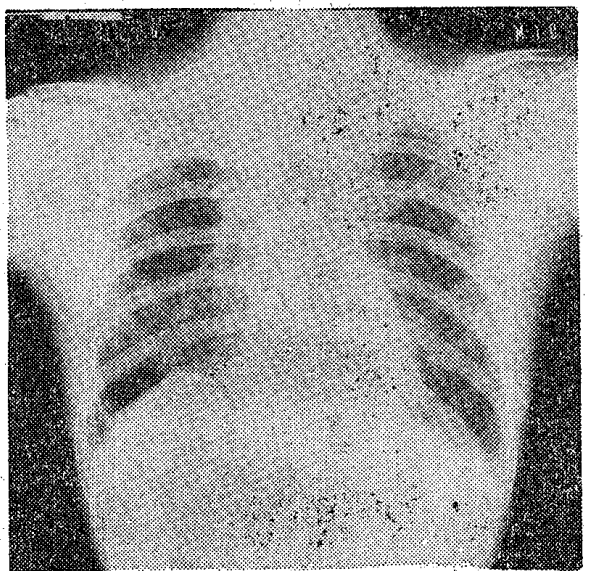

Fig. 64.
写真の一例であるが，濃度の薄い直接の原因は保安用夕 イマが働いた為であるがストロボ像が明白でないのが残 念である。

9-7 小括 3 租12パルスの波形について小括してみる と,

1. 3 相12パルス装置は高压側の波形で調整しないと 世界的に知名度の高い装置といえども波形は悪い。

2. 二次㩰入方式の装置では特に一次投入電压と時間 亿問題が多い.

3. 一次投入に問題のある装置はタイマにあ問題が多 (2.

4. 簡便法としてストロボ法により測定する事手可能 である。

5.ストロボ法からタイマの近似的実測をする專が出 来る。

6. 管理面から装置のチェックに応用する事が出来る。

\section{0. 螢光眰による装置の実測について}

胸部X線撮影においては一般的に大電流短時間で使用 しているので線量計では比較 的測定しにくい. そこでマッ キの螢光量計を使用してシー メンス，島㴖，柬装，日立の 内外四社の3 相之単相装犆に ついて比較梌討を試みた。測 定方法は Fig. 65 でアルミ板 は焦点と營光量計の中間で操 作した。

10-1 多重絞りのアルミ厚 について 日常使用している 多重絞りのミラーはフィルタ を兼ねているのが現状で，乙 のミラーが゙の程度のアルミ

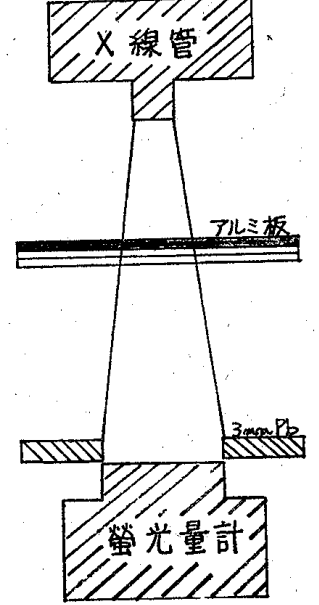

Fig. 65.

アルミ当叟測定法
厚に相当するか一般に明らかでない。そこで多重絞りを 取外して管球加らの直接線をX線管電圧 $60 \mathrm{kV}, 200 \mathrm{~mA}$, 0.1 秒で純度 $99 \%$ 標準アルミ板を入れて測定し，更に 多雷を附加した時の測定值と比較してアルえ譍算出し

Table. 7 多重絞り乏ラーのアルミ懕

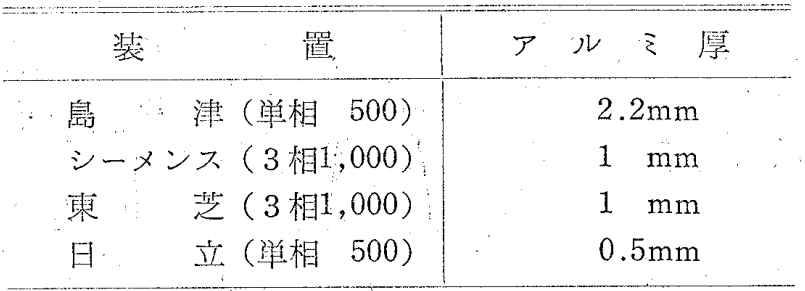


たもので，その結果は Table. 7 の通りで最も多いミラ 一は舄津の $2.2 \mathrm{~mm}$, 最毛薄いのは日立の $0.5 \mathrm{~mm}$ で装置、 によってかなりの差のある事が判明した.したがってミ ラーのアルミ厭は早急に規格化の必要がある.

10-2 装置別螢光量特性曲線装置による特性曲線は, 管電圧 $60,100,120,140 \mathrm{kV}$ で管電流は $200 \mathrm{~mA}$ (但し単 相装置については $140 \mathrm{kV}$ のみ $100 \mathrm{~mA}$ で測定し 2 倍し た）照射時間 0.1 秒，その結果はFig.66〜Fig. 69 の通 りで營光量としては東芝製の 3 相 12 パルスが最む多い.

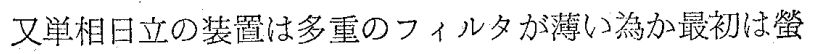

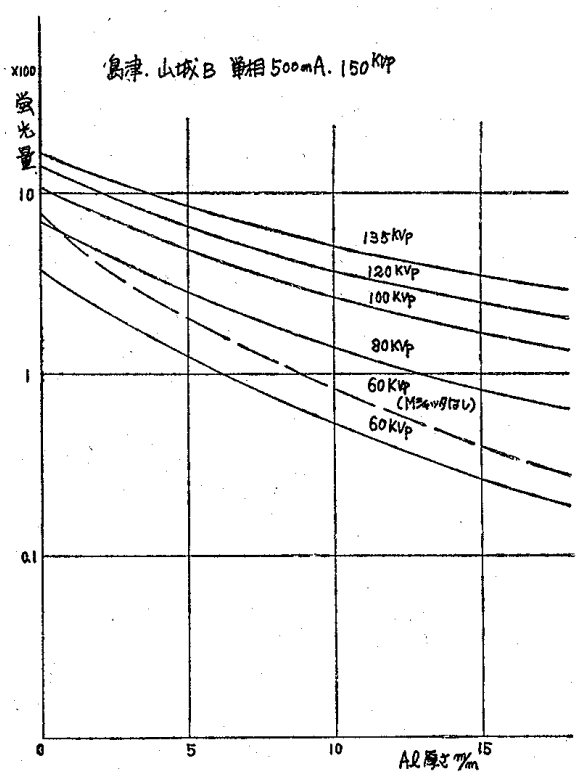

Fig. 66. 息津山城B 酋相 $500 \mathrm{~mA}, 150 \mathrm{kV}$

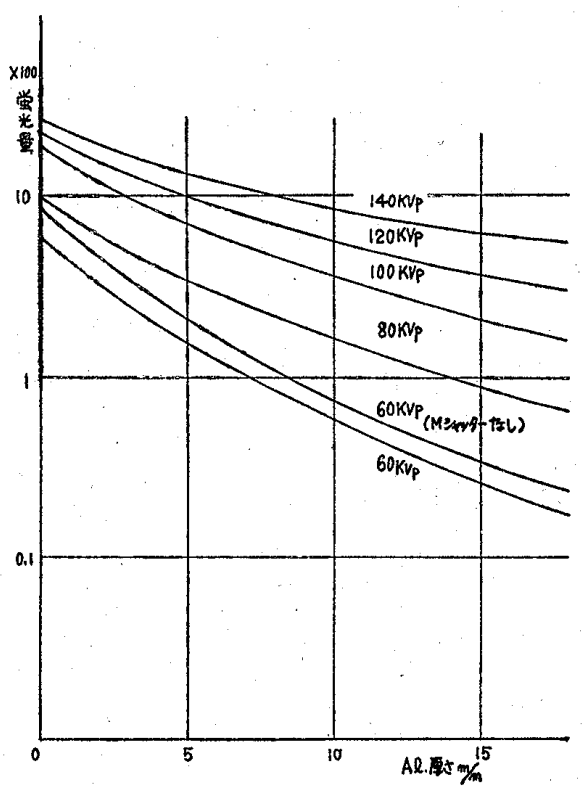

Fig. 67. シーメンスギガントス $3 \phi 12$ 1゚ルス。 $1,000 \mathrm{~mA}$

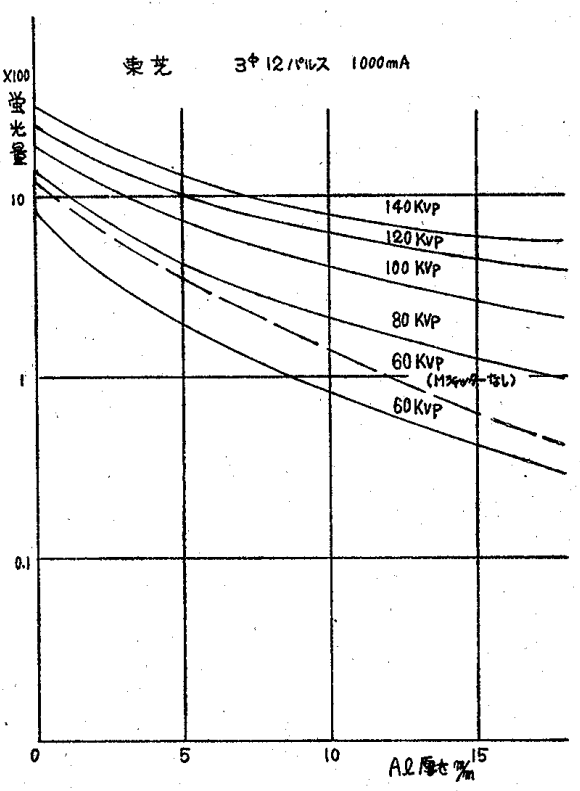

Fig。68. 東琶 $3 \phi 12$ パルス $1,000 \mathrm{~mA}$

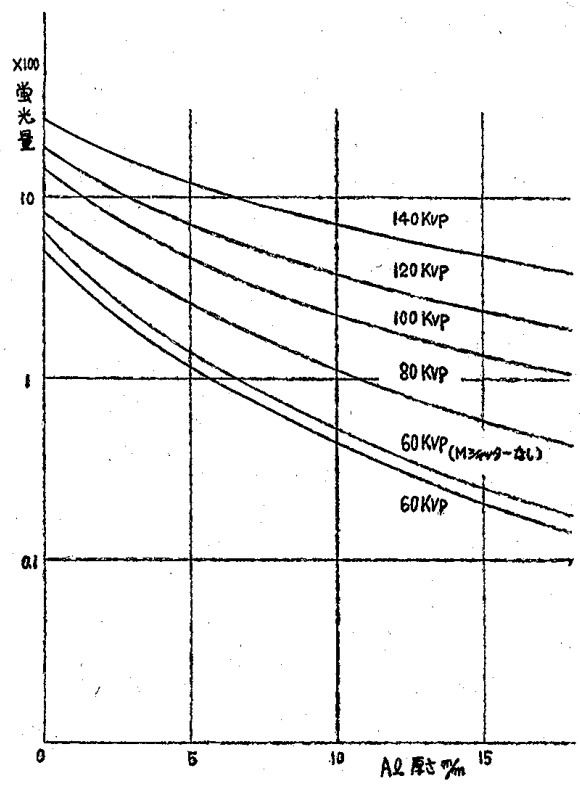

Fig. 69. 日立単相 $500 \mathrm{~mA}, 150 \mathrm{kV}$

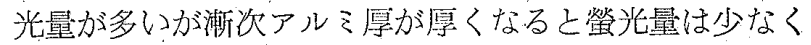
なる、したがって螢光量特性曲線は装置によってかなり の相違がある.又との測定結果汃ら头価鹰に相当するア ルミ擪が簡篗に算出する事屯出来る。

10-3 半洒尿相当アルミ厚について 多重絞りを用い

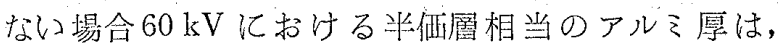
Table. 8 の通りで 3 相は，シーメンスが最す厚く $2.6 \mathrm{~mm}$, 東芝の $2.3 \mathrm{~mm}$, 単相では日立が最も薄く $1.7 \mathrm{~mm}$ であ る。

10-4 多重使用時の半価層相当アルミ厚について 多 
Table. 8 多重なし $1 / 2$ 螢光量のアル之愿

\begin{tabular}{|c|c|c|c|}
\hline 装 & 置 & $\rho$ & 冷 \\
\hline 島 & 津（輧相 500） & & $1.8 \mathrm{~mm}$ \\
\hline シーx & ス (3 相 1,000$)$ & & $2.6 \mathrm{~mm}$ \\
\hline 東 & 卦 (3 相 1,000$)$ & & $2.3 \mathrm{~mm}$ \\
\hline 日 & 立（単相 500） & & $1.7 \mathrm{~mm}$ \\
\hline
\end{tabular}

Table. 9 多重絞り使朋時 $1 / 2$ 螢光量のアルミ厚

\begin{tabular}{|c|c|c|c|c|c|}
\hline 装＼cjkstart置 & $60 \mathrm{kV}$ & $80 \mathrm{kV}$ & $100 \mathrm{kV}$ & $120 \mathrm{kV}$ & 備 考 \\
\hline 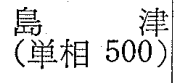 & $3.0 \mathrm{~mm}$ & $3.9 \mathrm{~mm}$ & $6.0 \mathrm{~mm}$ & $7.0 \mathrm{~mm}$ & $\begin{array}{l}200 \mathrm{~mA} \\
0.1 \mathrm{sec}\end{array}$ \\
\hline $\begin{array}{l}\text { シーメンス } \\
(3 \text { 相 } 1000)\end{array}$ & $2.2 \mathrm{~mm}$ & $3.5 \mathrm{~mm}$ & $4.6 \mathrm{~mm}$ & $5.2 \mathrm{~mm}$ & \\
\hline$(3$ 相 1000$)$ & $1.9 \mathrm{~mm}$ & $3.0 \mathrm{~mm}$ & $3.9 \mathrm{~mm}$ & $4.3 \mathrm{~mm}$ & \\
\hline 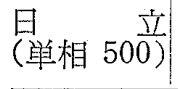 & $1.9 \mathrm{~mm}$ & $3.4 \mathrm{~mm}$ & $4.1 \mathrm{~mm}$ & $4.7 \mathrm{~mm}$ & \\
\hline
\end{tabular}

重絞りを使用した通常の撮影状態で半価層相当のアルミ 厚を算出してみるとTable.9のようになり，厚い順では 島津，シーメンス，日立，東芝の順に薄くなる。乙れは 装置の基本的問題と多重のミラーに関係する事は勿論で 特に東芝製 3 相 12 パルスは投入電压之撮影時間飞問題の ある事分推測出来る。

10-5 小括 これらの実測結 果を小括すると

1.ミラーのアルミ厚はメーカ によって異なる。

2. 最あ多いるラーは $2.2 \mathrm{~mm}$ であった。

3. 螢光量特性曲線は量的に加 なり相違がある。

4. 3 相 12 パルスの量的相違は 装置の基本的問題にも関係す る.

5 . 營光量曲線加ら半価層相当 アルミ厚を算出する事が出来 る.

6. 管電压 $60 \mathrm{kV}$ 亿抒ける多 重なしの平仾層相当アルミ厚 は最高 $2.6 \mathrm{~mm}$ であった。

7. 一般的にミラーの厚い程半 価層租当のアルミは愿いが例 外ああった。
8.ミラー用アルミ嬮の規制の必要がある.

\section{1. 単相と 3 相の比較}

11-1 線量比較 3 相 12 パルス装置の調整が允分でな い之波形や撮影時間がくずれ易く，又種々の関係から量 的にも異なるので実験的に比較する事は困難で一般的に は Kulen Kampff の実験式から計算により求めた線量 が比較されている. 今水 $10 \mathrm{~cm}$ 亿打ける 単相と 3 相 12 パルスの線量を中西氏の計算から比較したものがTable. 10 で低圧 $50 \mathrm{kV}$ で 2.05 倍, 高圧 $150 \mathrm{kV}$ で 1.59 倍であ る・而し実際には螢光量の特性からも装置によってかな

Table. 10 線 量 比較

\begin{tabular}{c|c|c|c}
\hline \hline 電压 $\mathrm{kV}$ & 単 相 & 3 相12 パルス & 倩 \\
\hline 50 & 1 & 2.05 & 考 \\
\hline 60 & 1 & 1.93 & 水ファントム \\
70 & 1 & 1.85 & \\
80 & 1 & 1.80 & \\
90 & 1 & 1.76 & \\
100 & 1 & 1.73 & \\
110 & 1 & 1.70 & \\
120 & 1 & 1.65 & \\
130 & 1 & 1.63 & \\
140 & 1 & 1.61 & \\
150 & 1 & 1.59 & \\
\hline
\end{tabular}

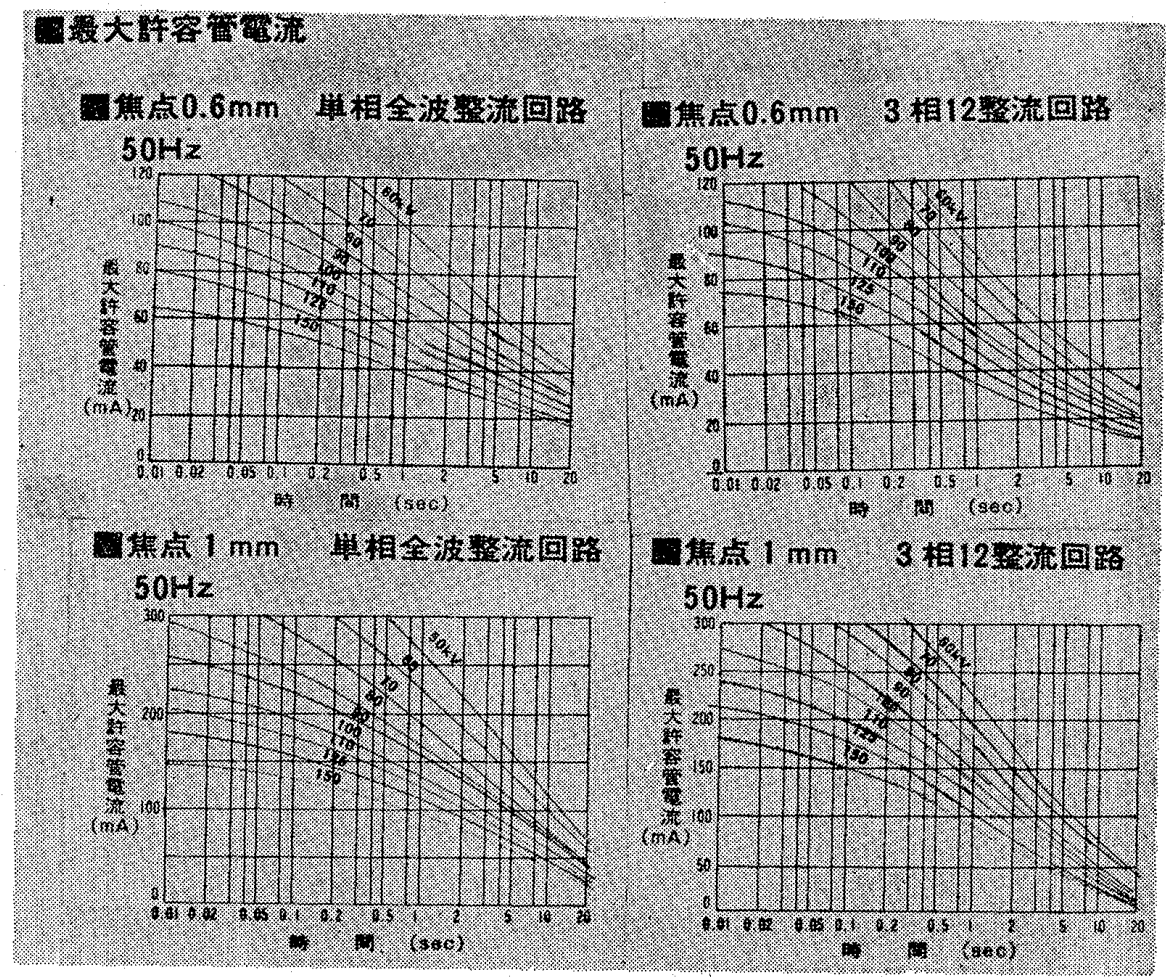

Fig. 70. 管球容量の比較 
り相違のある事は事実で，使用する特性を良く知ってお くととが有意義である.

11-2 管球容量による比較 同一管球を使用しても 3 相之単相とでは管球容量は異なり，一般的には 3 相 12 パ ルスは単相より15\%多く管電流を多く使用出来るといわ れているが実際某社の管球容量の比較は Fig. 70 で略々 10\%の増加である。

11-3 コントラストについて 現状の装置について水 ファントムとアルミ階段を使用して 3 相 12 パルスと単相 の比較を試みた。実験方法としてはグリッドを使用し， 透過線量を一定にする為にホトタイマを用いて可能な限 り㴗度を一定にして央験を行なった，その垁験方法が Fig. 71 で濃度の測定結果は $80 \mathrm{kV}$ が Fig. 72 で単相に比

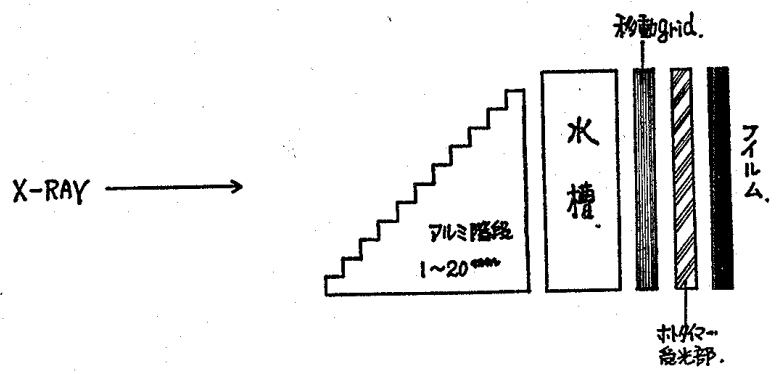

Fig. 71.コントラスト比較实験法
胸部写真の蹦床には有利で, 又単相と 3 相では実際には 写真の特性が多少異なる。したがって胸部写真で低濃度 部を一定にすれば 3 相12パルスの方がはるかに高濃度部 は高くなり，逆に高濃度部を一定にすれば単相の方が低 濃度部が高くなる，勿論との垁験には12：1のグリッド を使用したものである.

11-4 立証実験 前述の実験から臨床的には肺野の最 高濃度を基準にした場合と中央陰影内の低濃度部を基準 にした場合では 3 相 12 パルスと単相では裖度の違う事を のベたが，水ファントムで調整したホトタイマで同一電 圧, 電流で同一被写体を撮影して比較実験を試みた。そ の結果単相の場合低濃度部は 3 相 12 パルスより約 0.02 濃 度は高く, 逆に高濃度部では0.18濃度は低い。したがっ て前の実験結果とよく一致している．とのように 3 相 12 パルス装置の実際上の利点から小容量の経済的装置の開 発を期待したし.

11-5 小括 以上単相と三相 12 パルスについての比較を 小括してみると，

1. 水 $10 \mathrm{~cm}$ の計算による線量比較は $50 \mathrm{kV} 22.05$, 倍，120kVで1.65倍で $150 \mathrm{kV}$ で1.59倍である.

2. 管球定格は0.01秒で計算的には約 $15 \%$ 高く使用出 来るが，実際には約10\%の管電流の増加で屴る。
80KVPK然昧比较

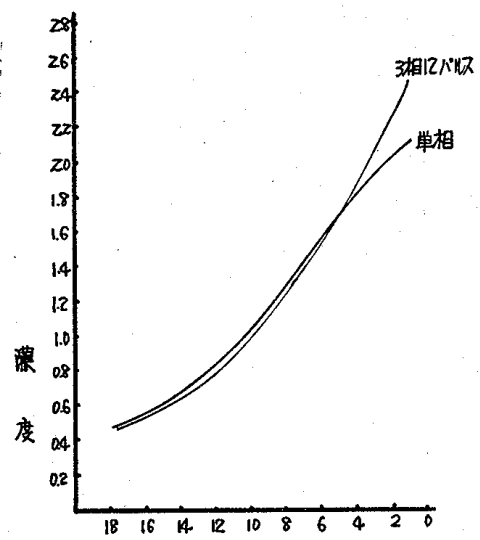

ALMi STEP

Fig. 72. $80 \mathrm{kV}$ 亿括ける比較

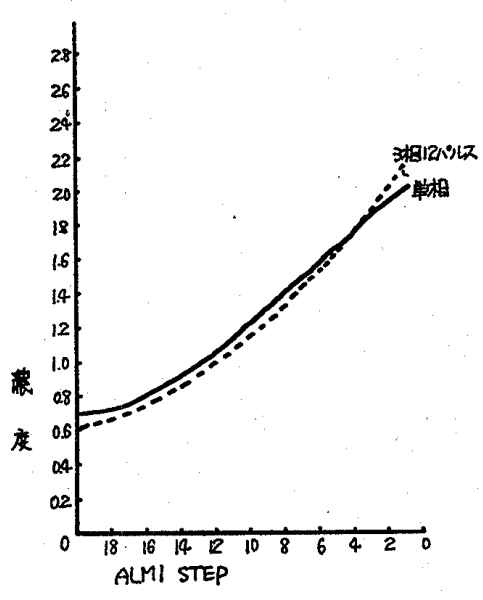

Fig. 73. $120 \mathrm{kV}$ における比較

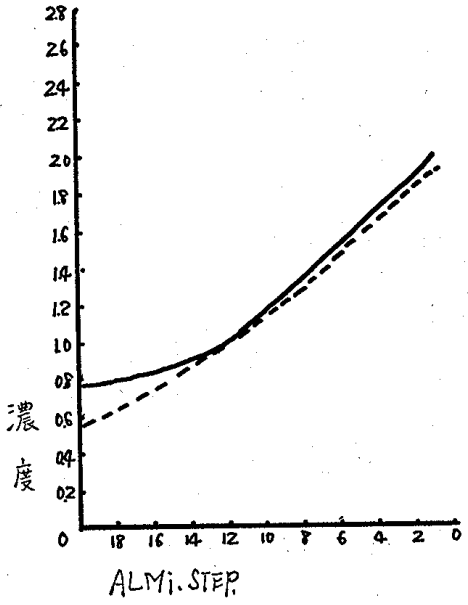

Fig. 74. $140 \mathrm{kV}$ における比較
し 3 相の方がコントラストスケールは長い.Fig.73 は $120 \mathrm{kV}$ で同様の傾向にある.とこで注目して頂きたい 事は単相の方が低濃度部の黑化がかなり高く低濃度部の 階調性が悪くなる.Fig.74は140 kV 亿おける濃度曲線 であるが $120 \mathrm{kV}$ より更に 単相低濃度部の濃度が上昇し ている。したがって单相装置においては電圧の上茬と共 にコントラストスケールが短かくなる。乙れは散乱線の 影響による事が推測出来る。この事から 3 相装置の方が
3. 単相と 3 相（6パルネ）の比較においても 3 相の 方がコントラストは良い。

4. 水ファントムを使用したアルミ階段の実験におい ては 3 相 12 パルスの方がコントラストスケールは長 W.

5. コントラストスケールが長いので 3 相 12 パルスの 方が胸部臨床写真としては有利である.

6. 単相と 3 相では写真の特性が多少異なる。 


\section{2. 胸部写真における優良性の 基本的な関係}

胸部写真の優良性を判定する基本的な関係については Table. 11 のようになり，乙れらの点を充分に配慮の上 で胸部X線写真を撮影する事が最も重要である。

Table. 11 胸部写真における優良性の基本的な関係

1. 濃 度一適正

2. 歪一入射X線と体位

3. 大きさ-F.F.D.

4. 鮮鋭度

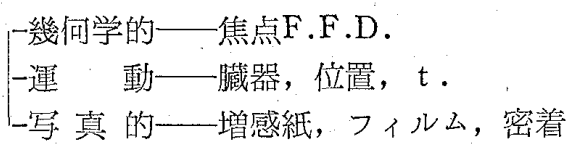

5. 対比度

-X 線 的一一電圧, 散乱線

一写真 的一フィルム, 増感紙, 喑室処理

6. 愦読影の原因となる人工描写物の排除

7. 情報量一多い

8. 病態生理学的加らの撮影

\section{3. 良好なる胸部写真を得る要件}

胸部写真の基本的な要求を充足する為にはおよそ， Table. 12 の要件で略々满足する結果を得る事が出来る.

Table. 12 良好なる胸部写真を得る要件

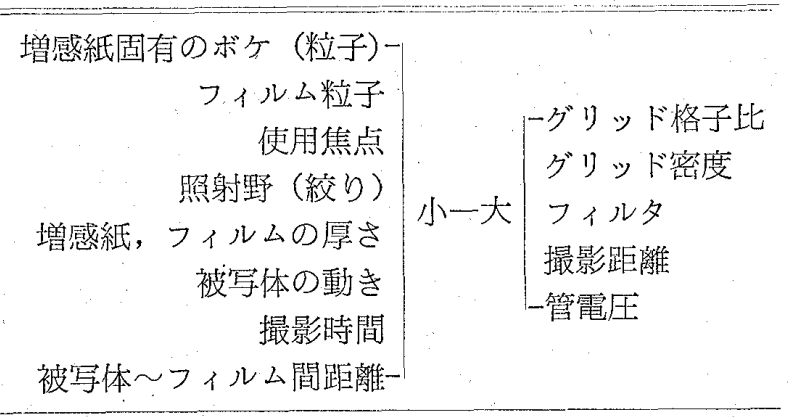

\section{4. 線䕊制御法の諸問題}

14-1 線量制御法の沿革 線量制御法についてはTable. 13 のように約 45 年前の1929年ドイッ人 Frankoによって X線照射自動遮断器を提案したのが初まりで, 本邦にお いては昭和 26 年第10回日本医学放射線学会に菄北大学と 東芝の試作発表があり, 翌27年東芝より商品化された。 更に直接用示トタイマは昭和 31 年第15回日本医学放射線 学会に拈りて大阪レントゲンより発表展示された。又日
Table. 13 線量制御法の沿革

1929年 ドイッ人 Franko 氏がX線照射自動遮断器 を提案

1930年 Müller 商会汃らX線照射自動遮断器発売

1941年 Frank. Bischoff. Runp. Nefechew らの共 同研究で自動遮断器の創作開始

1941年 アメリカ人の Morgan Hodges の雨氏が胸 部X線技術汇関する二次電子増倍管の実用 的応用を発表

1944年 Morgen Hodes がX線撮影技術全般に応用 出来る事を報告

1945年 Franke は新照射自動遮断器が満足すべき 結果を得た事を報告

1947年 General Electoric 社で最初の Photo timer が埛品化された。

本放射線技術学会に括いては1952年第 8 回総会において 東芝の田中氏がホトタイマの性能についてと題して報告 したのを第 1 歩として現在迄胸部に関係する主なる演頙 だけでも 40 題をこ光非常に多数である.

14-2 線量制御法の原理 線量制御法は大別して電離 槽方式と光電管方式に区別する事が出来る．前者をイオ ントマートといい, 後者をホトタイマと呼び種々の問題 から本邦に於てはホトタイマの方が普及率は高い。簡监 な一般的原理は Fig. 75 の通りである.本研究において
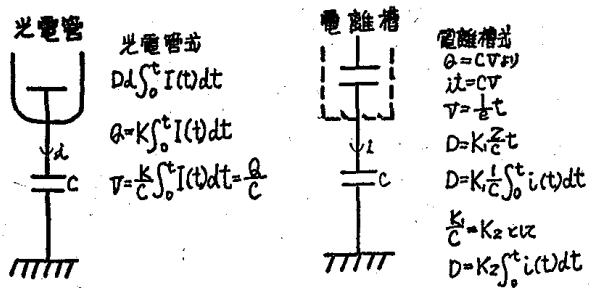

Fig. 75. 自動線量制御方式の原理

は主として後者のホトタイマについてのべる。

14-3 受光部の型式と吸収特性 現在本邦において使 用されている受光部の型は非常に多いがおよそ Fig. 76

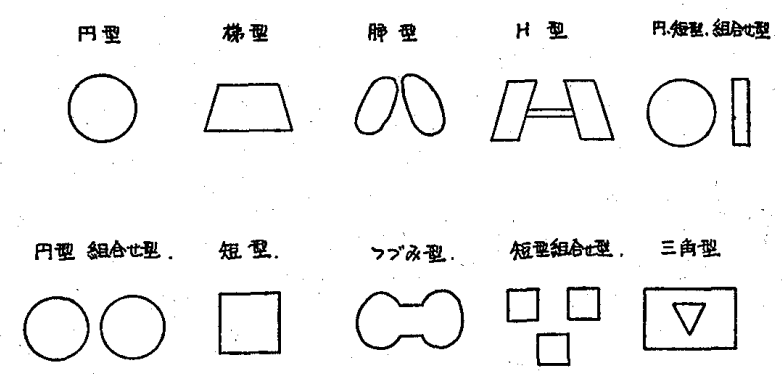

Fig. 76. 受光部の型式 
のように分類出来るが，大きさ材質等でかなりの問題が 予測出来る、筆者が使用した受光部の材質は Table. 14

Table. 14 受光部棈成材料例

\begin{tabular}{|c|c|c|c|}
\hline 1. 螢 光 紙 & $0.36 \mathrm{~mm}$ & X線吹收率 & $2.3 \%$ \\
\hline 2.アクリル板 & $1.00 \mathrm{~mm}$ & X線吸收率 & $1.53 \%$ \\
\hline 3. 銀 & $0.06 \mathrm{~mm}$ & X線吸収率 & $0.46 \%$ \\
\hline 4. 遮 光 紙 & $0.25 \mathrm{~mm} \times 2$ & X線吸収率 & $0.23 \%$ \\
\hline $\begin{array}{l}\text { 5. ベーク板 } \\
\text { 6. 金 枠 }\end{array}$ & $0.3 \mathrm{~mm} \times 2$ & X線吸収率 & $0.98 \%$ \\
\hline
\end{tabular}

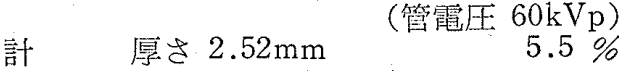

に記載のタングステン酸系のものを使用した。乙の受光 部は厚さむ薄く $3 \mathrm{~mm}$ 以内で, $60 \mathrm{kV}$ にお就る吸収率は $5.5 \%$ 以内である。

\section{5. 単相用ホトタイマの諸問題}

15-1 1 パルスにおける誤差 単相用ホトタイマに， SCRを使用するとMGSの時間遲れをなくす事が出来る 事はすてに周知の処で，乙れは MGS が位相 0 亿おいて 正確に開閂する為である。今笚相 1 パルスの愦差につい てみると Fig. 77 の通りで短時間側ではその影響は非常 に大きい。

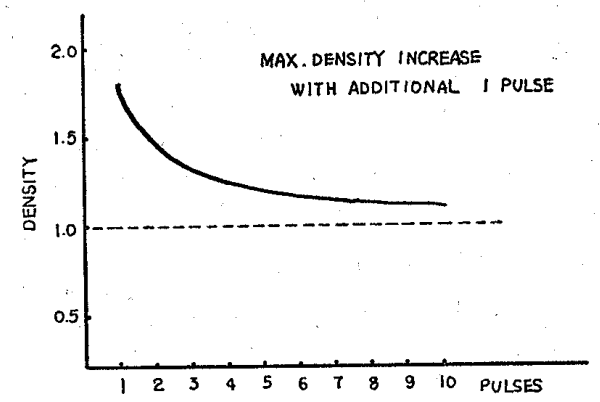

Fig. 77.

15-2 M.G.S 式と S.C.R 式の特性比辠 実験飞使用し たホトタイマの受光部は Fig. 78 でタングステン系H型

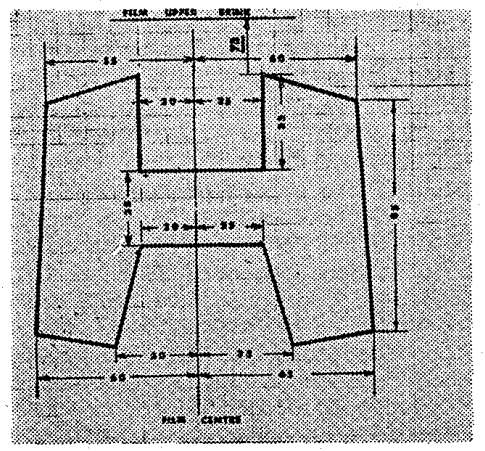

Fig. 78. Shape \& Size of pick up field

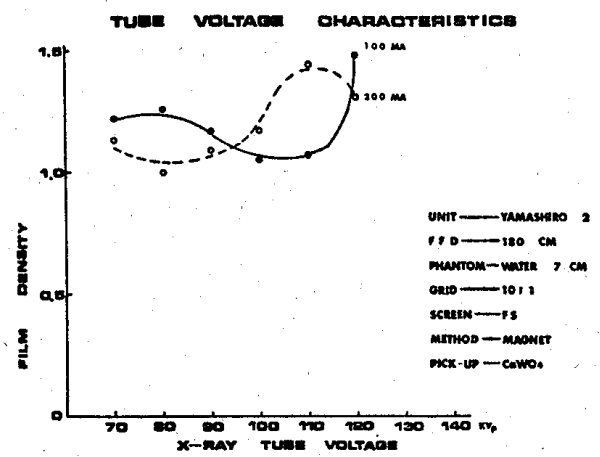

Fig. 79 受光部の材質による特性 (タングステン系，電磁開閉式）

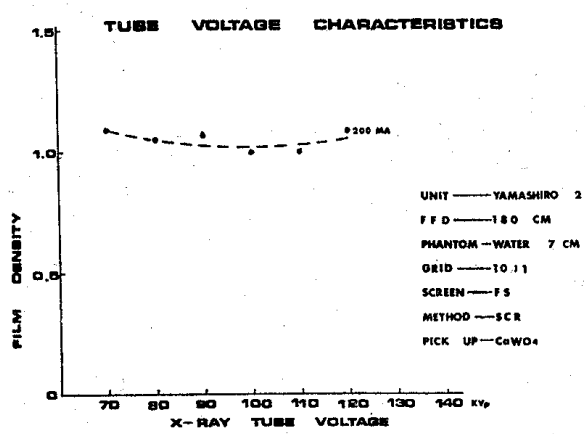

Fig. 80. 受光部の材質による特性 （タングステン系 SCR 式）

でSCRなしで，水ファントムを使用した笑験では Fig. 79 のように電圧の変化にともない濃度は異なる. 又管電流を変化しても濃度差は大きく实用上不適正であ る。そこで SCR を取付讨た実跧では同じ装置でもFig. 80 特性になり管電圧，管霞流の差を除去する事が出来 る.

15-3 受光部の材質による特性 受光部の光電流を多 くしてホトマルの精度をカバーする事が考えられ，その 材質として硫化系の受光部が試作され実験を試みたが， Fig. 81 のように 電压の上昇と共に 濃度は上昇して不適

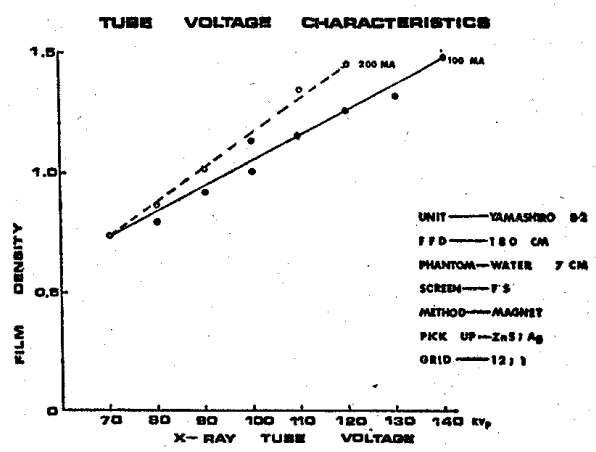

Fig. 81. 受光部の材質による特性 （硫化系電磁间閉式） 


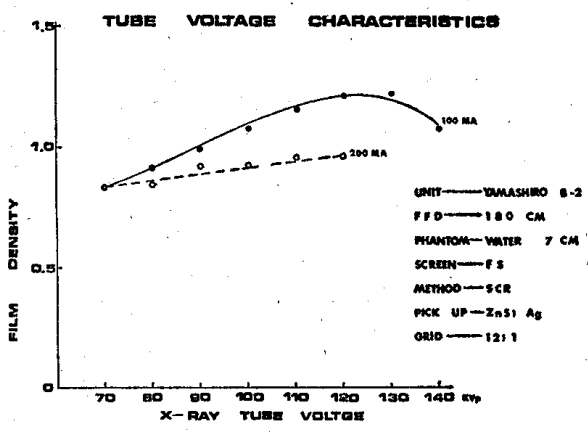

Fig. 82. 受光部の材質による特性 （硫化系 SCR 式）

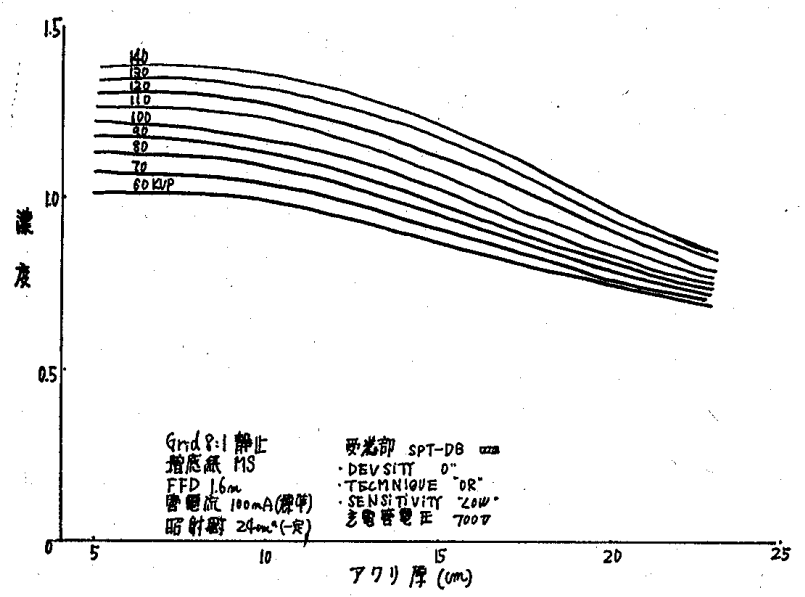

Fig. 83.

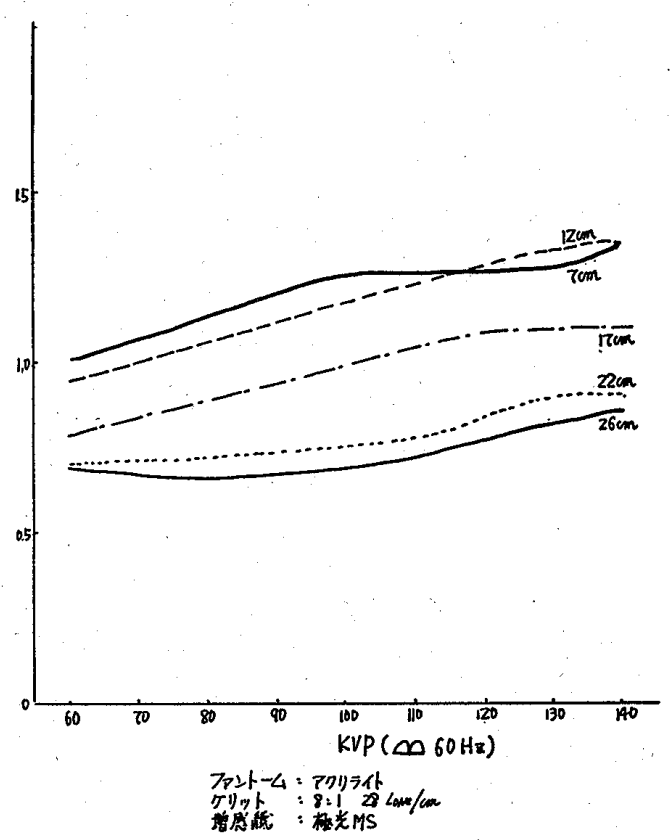

Fig. 84. 分割測光式ホトタイマー特性

正で，更にSCR による調整を試みたが Fig. 82 の如く 依然として電圧, 電流による特性が強く胸部用としては
硫化系の受光部は不利である.

15-4 分割測光式について 胸部写真は特に再現性の 高い事が重要で，その為にホトタイマが有効であるが基 礎実験として水ファントム又はアクリライトのような均 等なファントムを使用した場合の濃度の許容誤差は 0.1 附近である.分割測光式は理論的には左右の肺を别々に 制御する事を目的に開発されたすのでこの方式による電 圧特性は Fig. 83 のように電压による濃度差は非常に大 きい. 更にこれをアクリライトファントムによる厚さ特 性の実験結果はFig. 84 でかなりの濃度の違いがある.

これは受光部の問題と使用するホトマルの特性や左右の 螢光量に起因する事が推測されるが，性能的に基本的な 問題の再検討が必要で現状においては胸部用としては不 適正である。

15-5 完全自動式について との方式は管電圧，管電 流共に一定範囲内で自動的に設定する方式で一次側の抵 抗を急激に変化して管電圧を上昇させ，管電流を少なく する方式で最大值までの変化する時間は 6 〜 8 パルスで ある.との管電在と管電流波型の一例が Fig. 85 で基礎

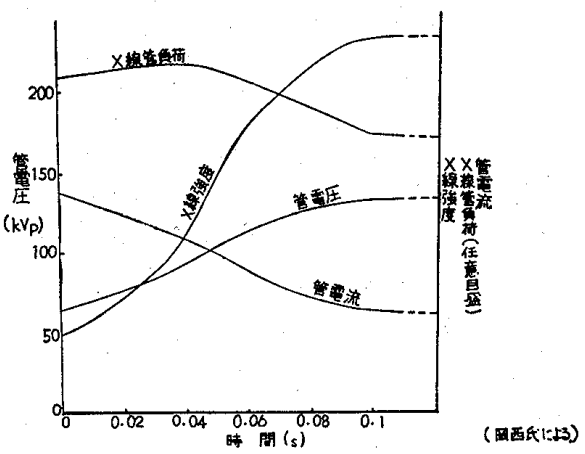

Fig. 85.

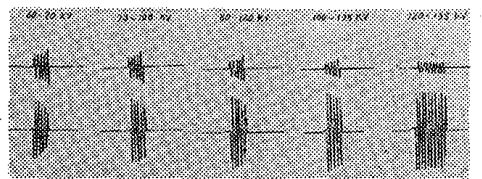

Fig. 86. 胸部用完全自動式ホトタイマ基礎実験

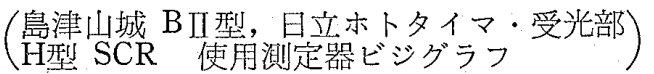

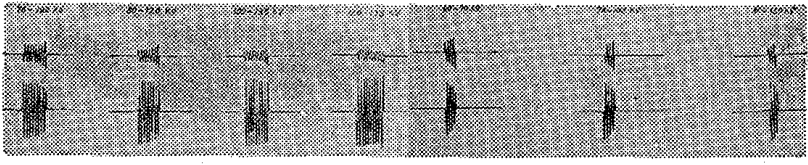

ファントム水 $13 \mathrm{~cm}$ 島津山城 B【I型，日立示卜 タイマ 受光部 $\mathrm{H}$ 型 $\mathrm{SCR}$ 使 用 測定器ビジグラフ
ファントム $7 \mathrm{~cm}$ 島津山城 BII型, 日立小ト タイマ受光部 $\mathrm{H}$ 型 $\mathrm{SCR}$ 使 用 測定器ビジグラフ
Fig. 87. 胸部用完全自動式ホトタイマ波形図 
実験のビジグラフは Fig. 86 のように最高電圧は $135 \mathrm{kV}$ であるがその間，例えば70１20kV等10数種類の実験の 結果, 数種に整理実用化してみた。水ファントムを使用 したビジグラフによる測定の結果は Fig. 87 で動作は良 好で, 又螢光量計による測定の結果は濃度的には $0.1 の$ 範囲内にあり実用性は克分である．との方式は電圧前示 式のホトタイマとして屯使用出来る.

15-6 ホトタイマの濃度差 ホトタイマの濃度差を生 じる原因は基礎的なものと，技術的なものがあり，基礎 的なむのとしては受光部の材質による電圧特性, 厚さ特 性，時間特性，管電流特性があるがこれらは製作者側の 技術によって実用上支障のない補正が出来る．技術的な あのとしては使用者側に主として問題があると考えられ， 同一装置を使用して屯濃度差が著しく出る場合がある。 そこでこれらの技術的な濃度差を出来るだけ少なくする 為に基礎的な実験を試みた。

基礎実験 1 実験法として受光部に異種吸収体がある 場合にどのような濃度差が生じるかについての実験方法 は Fig 88 である。その結果はFig. 89 の通りでパチンコ 玉や，ローソク片では沿んぞ濃度差は生じない。しかし

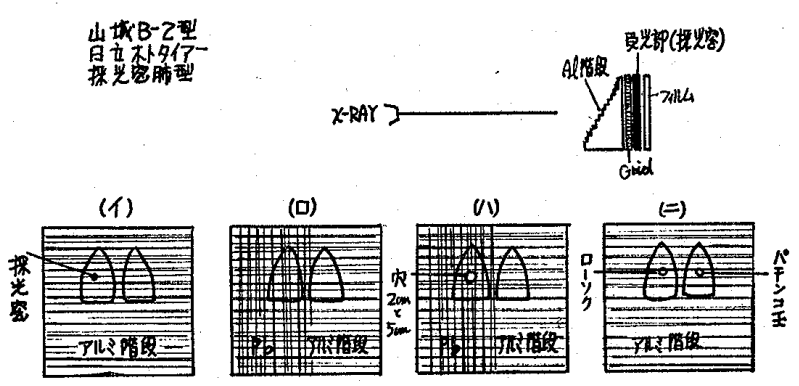

Fig. 88. 濃度差実験法（その 1 )

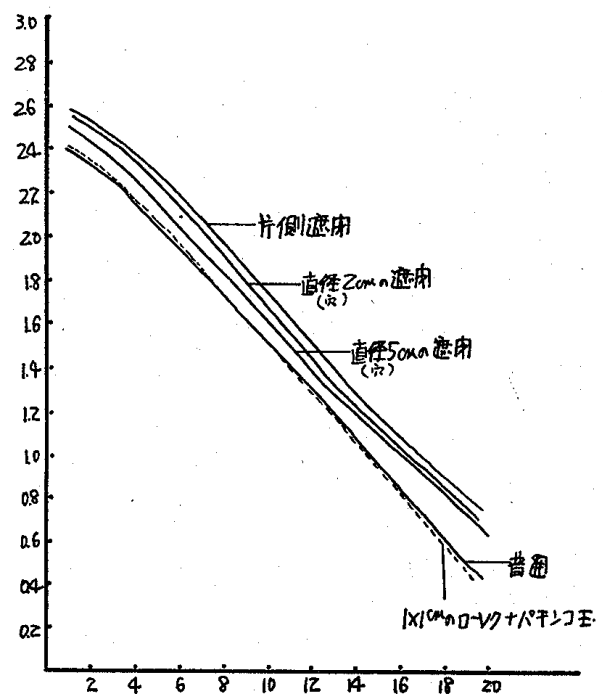

Fig. 89. 濃度差 (1)
受光部のある面積を遮閉した場合には濃度差は大きく上 尧する。

基礎実験 2 前の実験之は反対江受光部に直接線が入 った場合どのように濃度が変化するかの実験である．実 験方法は Fig. 90で作為的にアルミ階段を外した実験で， との実験結果は Fig. 91 亿示し；乙の場合異種吸収体が
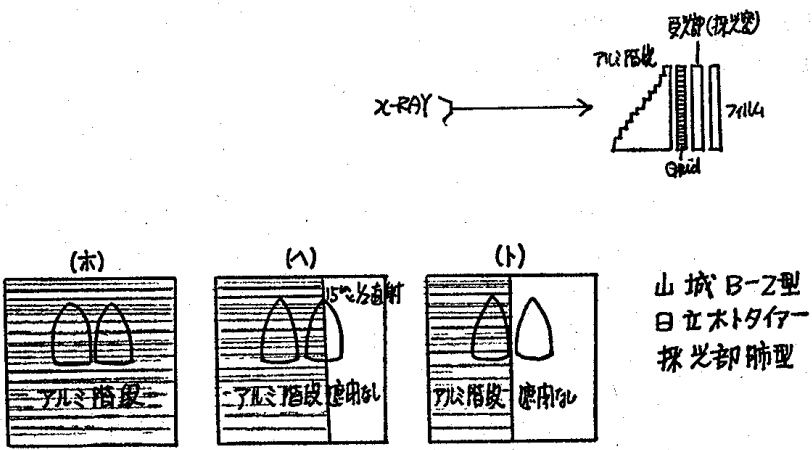

Fig. 90. 濃度差実験法（その 2 ）

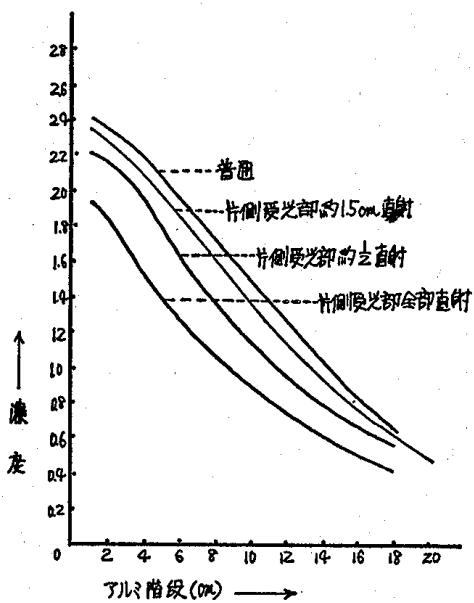

Fig. 91. 濃度差 ( 2 )

受光部の上にある以上にその影響は大きい.したがって 僅かの㨁射光であっても濃度の薄い写真が出来る. 更に 水 $7 \mathrm{~cm}$ の水槽を加えての実験を行なったが更に䀼度差 は大きくなる。乙れは側面撮影の如く被写体の厭い場合 に問題で，少しでも直接線が入ると非常な影響のある事 を示している。

15-7 濃度補正について 技術的に濃度差を生じる原 因として濃度が高くなる場合と浱度が薄くなる場合があ り，乙の調整の為ホトタイマに粗調整として 1 倍， 2 倍， $1 / 2$ 倍の 3 段階の調整法を使用し，更に 1 〜 11 まで10段階 の微調整器を使用した。

15-8 調整特性曲線 水ファントムを使用し微調整夕 ップを一段づつかえ螢光量を測定した。単相 SCR 使用 
の特性曲線は略々直線的に濃度補正が出来る。しかし特 に濃度が薄くなる場合には直線性がなくなる。これは時 間遅れによる誤差で実用上 3 パルス未満になるととの現 象が強くなる。

15-9 濃度過多になる場合の補正，受光部に異種吸収 体がある場合の補正法について実駼を試みると・Fig. 92 のようになり，微調整タップによって充分に補正する事 が出来る. 実際には片側整形手術を実施した患者で 1 2 タップで実用上支障のない濃度の胸部写真が撮影出来 る.

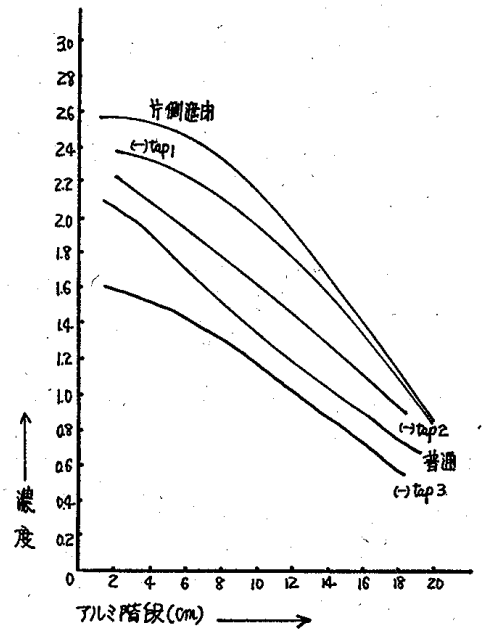

Fig. 92. 濃度補正の笑験（水槽 $7 \mathrm{~cm}+ア ル ミ$ 階段）

15-10 濃度が薄くなる場合の補正 前述とは反対に受 光部より被写体が外机, 直接光が入る場合の実験で, 結 果はFig. 93 の通りで，極端な場合は調整タップだけで は補正は困難で，乙の場合には增感紙による補正法が最 も効果的である。

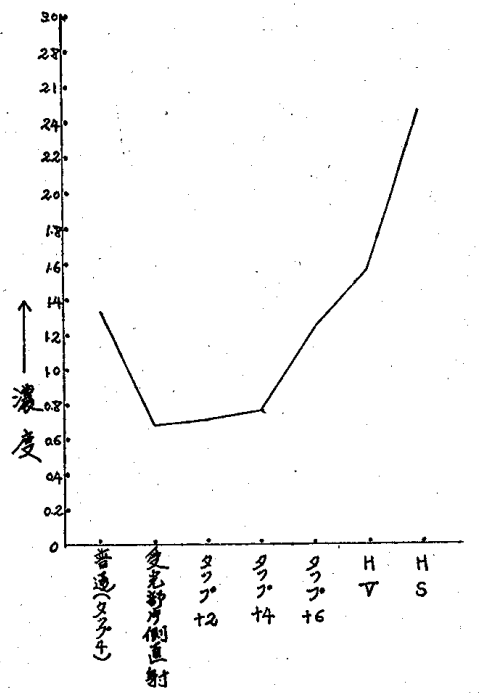

Fig. 93. 濃度補正の基礎実験（その:2)(水槽 $7 \mathrm{~cm}$ )
15-11 ポジショニングによる濃度差 胸部撮影の実技 上濃度差を生じ易い受光部の位置的関係は正面が Fig. 94 で側面は Fig. 95 のよになるが, 更に病紧, 術後の 場合は Fig. 96 でその中，濃度差は側面撮影時に最む起 り易いので特にポシショニングには充分に注意する必要
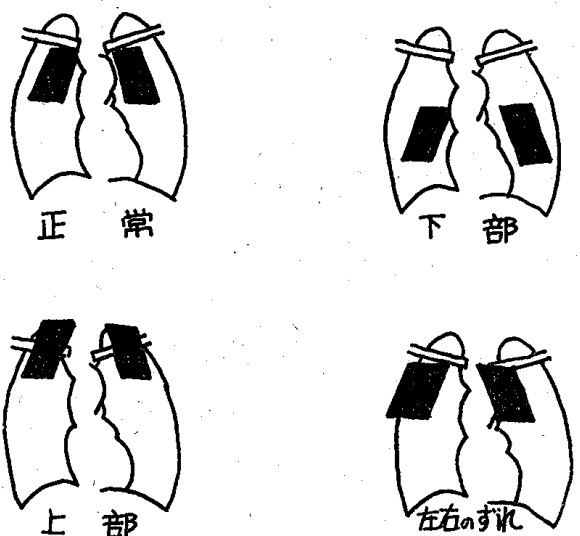

Fig. 94. 採光空の位置によるバラッキ
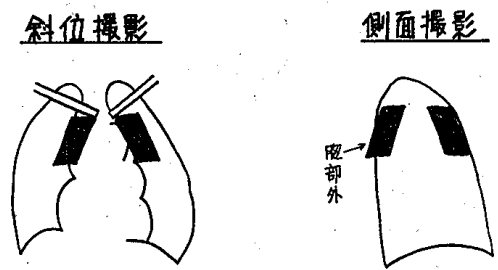

Fig. 95.

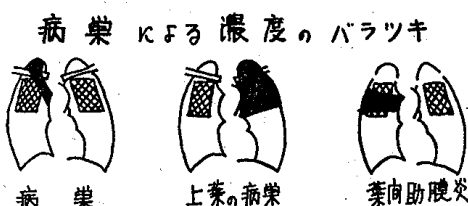

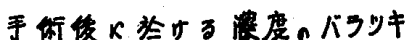
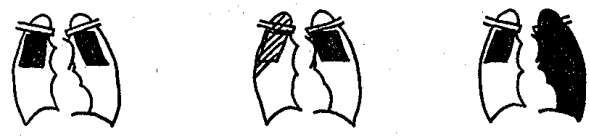

健康肺

成形柏

睤措出循

Fig. 96.

がある・撮影の実際に当ってはポジショニングの時, 背 面に傷のある人や，著しく体が歪えでいる人には一言何 か病気をした事がありますかと尋ねる事によって，かな り浱度差を減少する事が出来るので是非実施を衔めたい. 勿論受光部は何時も所定の位置づけをする事が基本であ る.

15-12 小括 以上単相装置のホトタ.イマについて知見 を小括すると， 
1. 単相用ホトタイマーは SCR で精度を问上する事 が出来る。

2. 線量の少ない場合の補正曲線は恶い。

3. 1 パルスの誤差は短時閪撮影では誤养は大きい.

4. 分割測光式は考え方としては理想であるが精度の 点で今後の装置である。

5. 濃度過多の場合の補正は簡単である。

6. 薄い場合の補正は困難で増感紙法がすぐれてい る.

7・ポジョョニングは受光部に正しく位圆をとらない

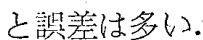

8. 完全自動式は前示式も兼用出来る.

\section{3 相用ホトタイマの譛問題}

3 相12パルス装置の使用目的で TRIAC によるホトタ イマの開発をした，乙れは SCR より小型に出来る事が 特徽で受光部はH型で Fig. 97のようにホトマ ルを水平に取付讨た撮影 台を使胿した。の試験 はまずFig.98のように 一次側で模㫐䞨配線をして 管球に筫街をかけない上 うにして基礎実験を試み， 動作の確実な罸が判明し たので笑用回路に直して トランスのブッシングか ら管球之並列にオイル抵 捖器を継ざ，オッシログ ラフで摱影した写真が Fig. 99 である.との波

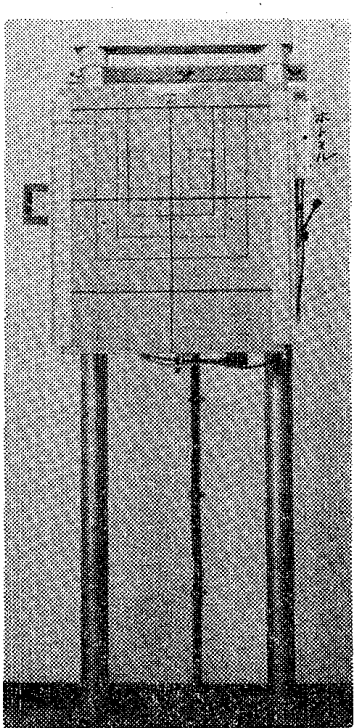

Fig. 97. 撮影尚 形は一次侧と同様で確笑に線量制御が実証された。

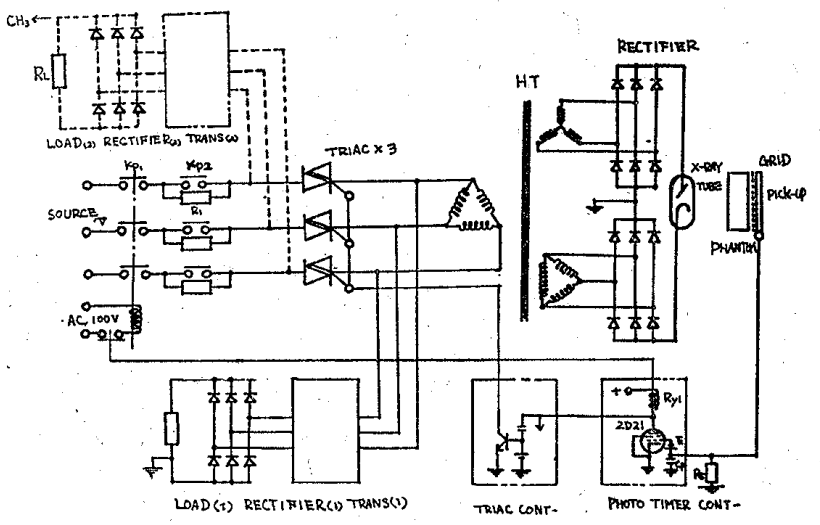

Fig. 98.

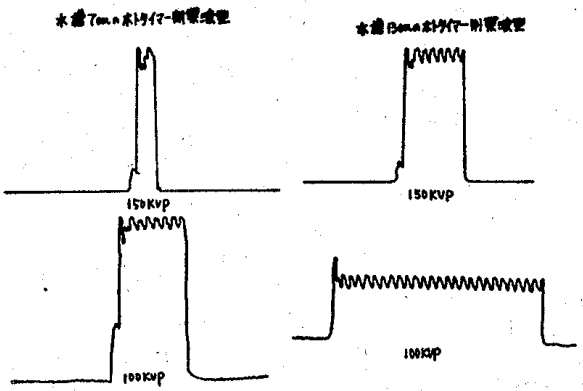

Fig. 99.

16-1 3 相用ホトタイマの特性 単相と同様營光量計を 使用した特性については MGS 方式の場合が Fig. 100で TRIAC 方式では Fig. 101 で（）内は推定時間であるが かなり精度のより專が判明した. 又補正方法に使用する

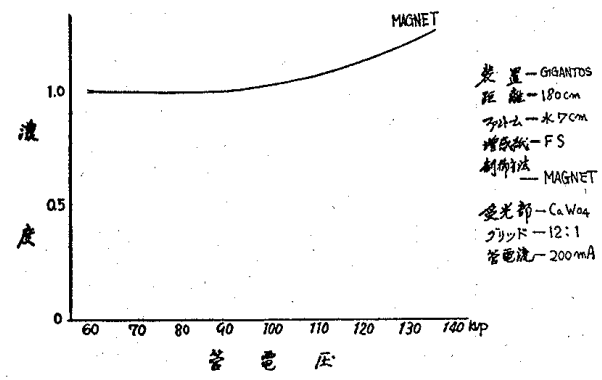

Fig. 100.

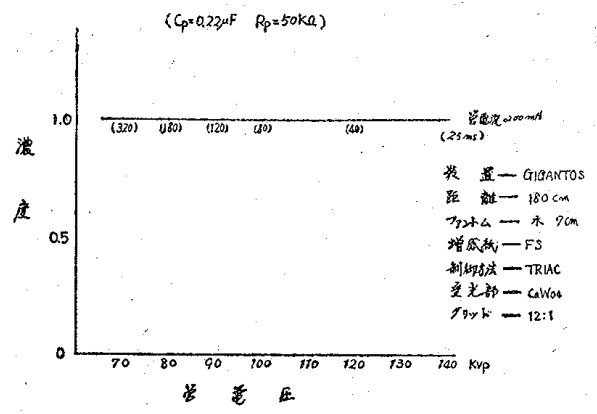

Fig. 101.

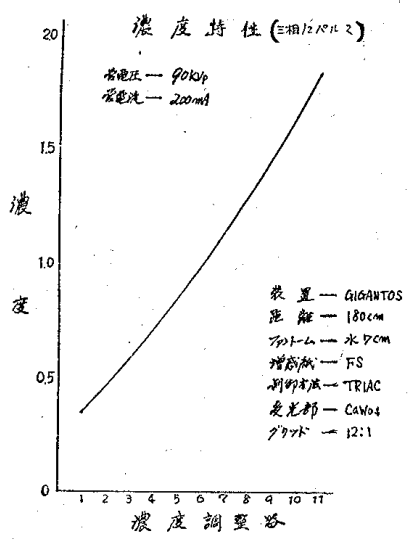

Fig. 102. 
補正曲線は Fig. 102 の通りで短時間側になってす直線的 に制御出来るのが単相との相違点である.

16-2 ホトタイマの問題点 フィルタによって線質を 人為的に変えた場合どのような濃度差を生ずるかについ てグリッドを使用した実験を試みると Fig. 103 のよう になり $\mathrm{Cu} 0.2+\mathrm{AL} 2 \mathrm{~mm} の$ 附加では約 0.1 程度の濃度 の上昇になる。したがって実際に使用の時は微調整タッ プを一段下げた位置で使用すればよい。次にグリッドを 外して実験を試みると，Fig.104 のように電圧が低くな れば受光部の材質による吸収の影響を受け易くなるので， 出来るだけ $60 \mathrm{kV}$ 以上で使用した方が濃度差は少ない。 又附加フィルタを使用した実験の結果は点線ざ, 濃度が かなり上昇した特性曲線になる事が判明した。よってグ リッドなしで使用する場合には特に注意が必要である。

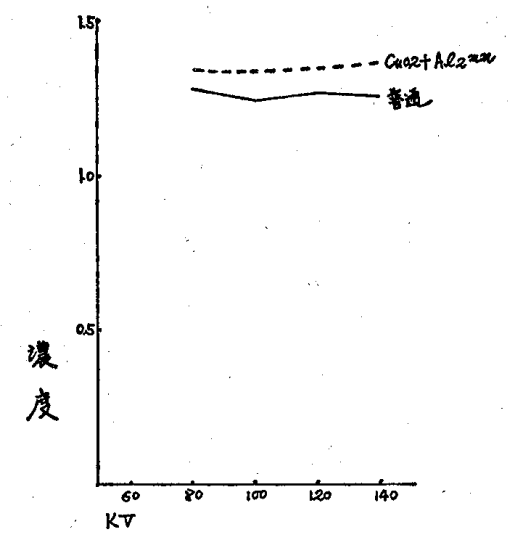

Fig. 103. グリッド使用時におけるフィルタの特性

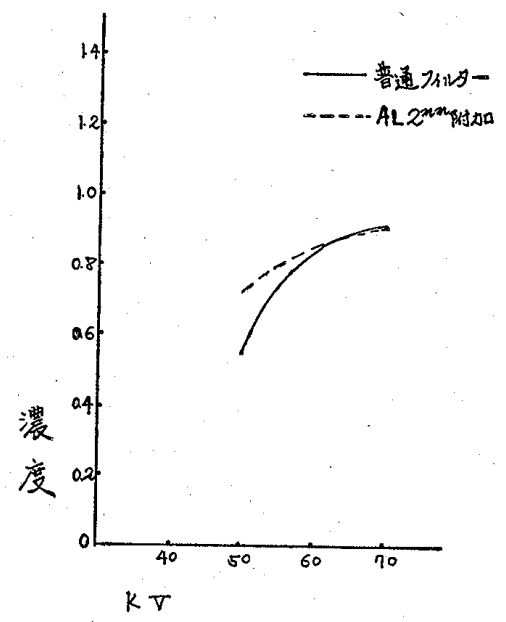

Fig. 104. フィルタによる特性（No グリッド）

16-3 散乱線とホトタイマ グリッドを使用しないで 散乱線を除去する場合にはグレーデル法が用いられる。 ての場合ホトタイマではどのように特性が変るかについ ての実験結果が Fig. 105 で $15 \mathrm{~cm}$ と $30 \mathrm{~cm}$ の距啄では

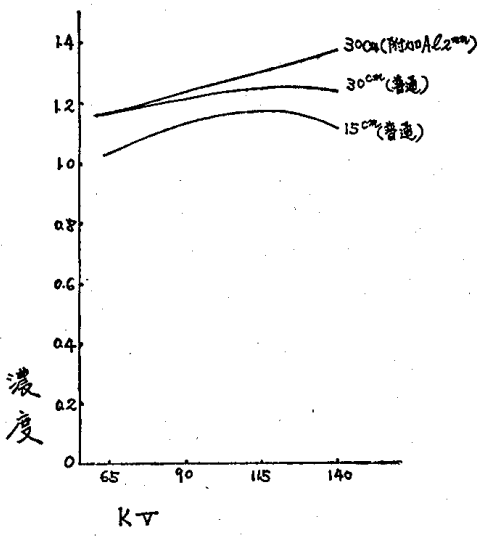

Fig. 105.・グレーデル法におけるホトタイマ特性

濃度美は 0.1 で更に AL $2 \mathrm{~mm}$ のフィルタを附加すると 更に濃度は上昇する。乙れらの事も立分に配慮する必要 がある.

16-4 小括 以上を小括するに

1. 3 相用ホトタイマは TRAIAC の使用により精度 は安定する。

2. 補正曲線も完全に線量の少ない処まで補正出来る.

3. 附加フィルタによって特性はととなる.

4. $60 \mathrm{kV}$ 未満では受光部の材質の影響を受け易い.

5.グリッドなしの場合附加フィル夕により濃度を上 昇出来る.

6.グレーデル法でホトタイマの浱度は上昇する。

7.グレーデル法十フィルタで更に濃度は上昇する。

8. ホトマルの防護を完全にする必要がある.

\section{3 相装置の識別について}

3 相 12 パルス装置でホトタイマを使用し水 $7 \mathrm{~cm}$ と 13 $\mathrm{cm}$ のファントム, 管球焦点 $1.2 \mathrm{~mm}$ で, 細線法と穀物 法による実験でグリッド法, グレーデル法と低濃度部に ついては10円銅貨による実験を試みた。実験方法は， Fig. 106 の如く水ファントムの上に細線チャートと豰物 テャートを使用し，それぞれ電圧を変えて撮影したすの を肉眼的観察法において比較した.

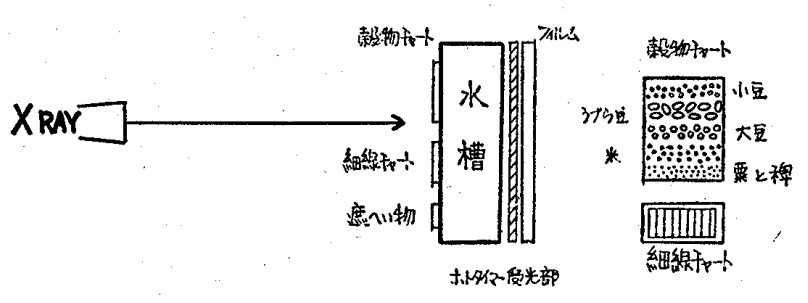

Fig. 106. 実験方法 (イ

17-1 グリッドなしの示現 グリッドなしの場合の示 
現は細線法では Fig. 107 で水 $7 \mathrm{~cm}$ では $0.15 \mathrm{~mm}$ ，水 13 $\mathrm{cm}$ では0.2 $\mathrm{mm}$ で水 $7 \mathrm{~cm}$ に比しかなりの示現の低下が 認められる。乙の場合電圧が低い程差は少ない，次に穀 物法の結果は Fig. 108 で水 $7 \mathrm{~cm}$ では米迄認識出来るの に対し13 cm では小豆までである. 又アルミの $2 \mathrm{~mm}$ 附加した場合，細線法はFig. 109 で，穀物法はFig. 110 であるが示現は普通フィルタよりも僅かに低下の傾向で， 細線法，款物法共に細加い方の(土)が少なくなる。
グリッドなしの増感紙の比較

胸部の代表的堌感紙 FS と LT-2 の比較した細線法が Fig. 111 でFS の方が僅かではあるが有利である、又款 物法による増感紙の比較はFig. 112 で FSの方が良好 で特に普通フィルタに於いて著明である。

17-2 グリッド法の示現 先の実験装置で, 水槽後部 にグリッドを配置して実験を行なった。その結果は細線 法の場合はFig. 113 で，水 $7 \mathrm{~cm}$ では電圧の低い㓅が示

\begin{tabular}{|c|c|c|c|c|c|c|c|c|c|}
\hline \multicolumn{10}{|c|}{ 水槽 $(7 \mathrm{Cm})$} \\
\hline 管電垕(KVp) & 0.06 & & & 0.15 & & 0.26 & 0.3 & & 0.5 \\
\hline 50 & -- & 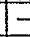 & \pm & + & + & + & + & & + \\
\hline 60 & $-1-$ & $z$ & \pm & + & + & + & +1 & & + \\
\hline 70 & $-1-$ & $1-$ & \pm & + & + & & +1 & & + \\
\hline \multicolumn{10}{|c|}{ 水槽 $\quad(13 \mathrm{~cm})$} \\
\hline 55 & $-1-$ & 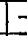 & -1 & \pm & + & + & + & & + \\
\hline 65 & $-1-$ & 17 & -1 & - & $F$ & $\mp$ & + & & + \\
\hline 75 & $-1-$ & $1-$ & $|-|$ & - & + & & + & & + \\
\hline 85 & 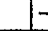 & & & & & & + & & + \\
\hline
\end{tabular}

管需流 $200 \mathrm{~mA}$

Fig. 107. No グリッドの示現結 果 (細線法)

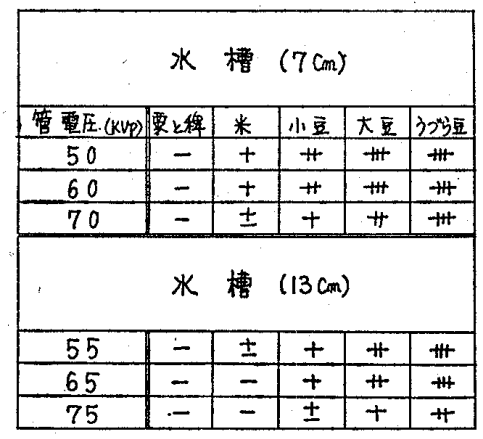

grid ( $(-)$ 管霓流 $200 \mathrm{~mA}$.

Fig. 110. フィルタ ( $\mathrm{Al} 2 \mathrm{~mm})$ 使 用時の示現（穀物法）

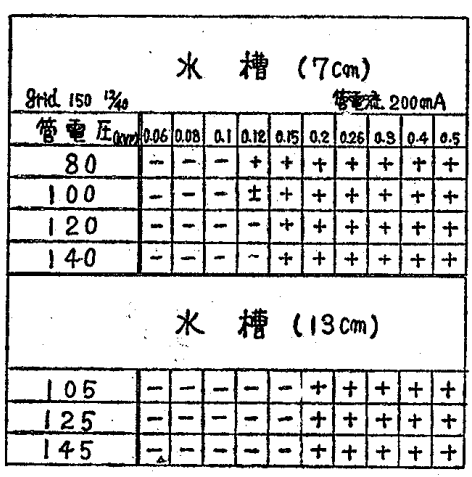

Fig. 113. グリッド法の示現 （細線法）

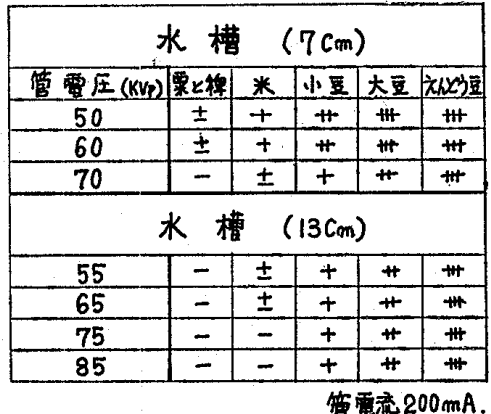

Fig. 108. No グリッドの示現結 果 (政物法)

管電压. $60 \mathrm{KV}$ 水槽 $(7 \mathrm{~cm})$

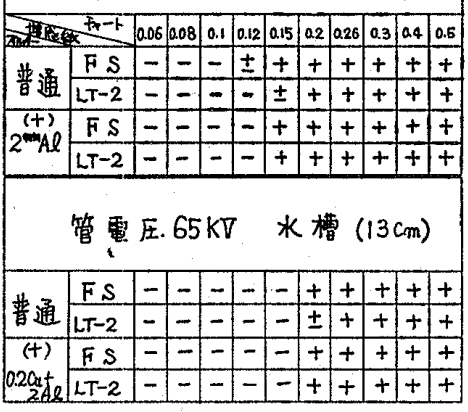

管電流 $200 \mathrm{~mA}$.

Fig. 111. 増感紙による比較 （細線法）

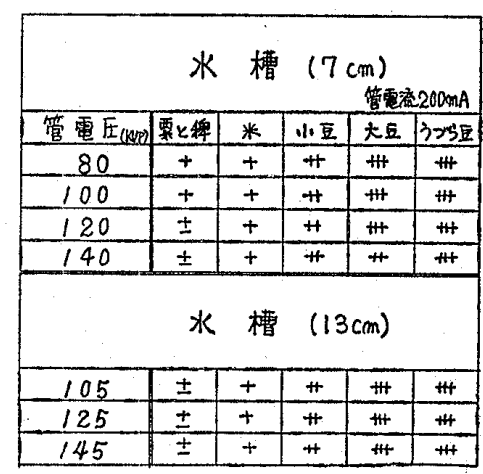

Fig. 114. グリッド法の示現 （款物法）

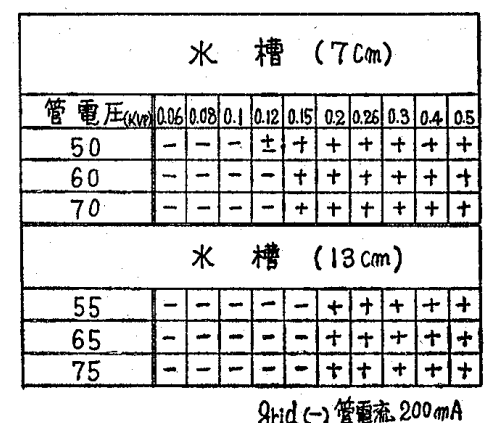

Fig. 109. フィルタ $(\mathrm{Al} 2 \mathrm{~mm})$ 使 用時の示現（細線法）

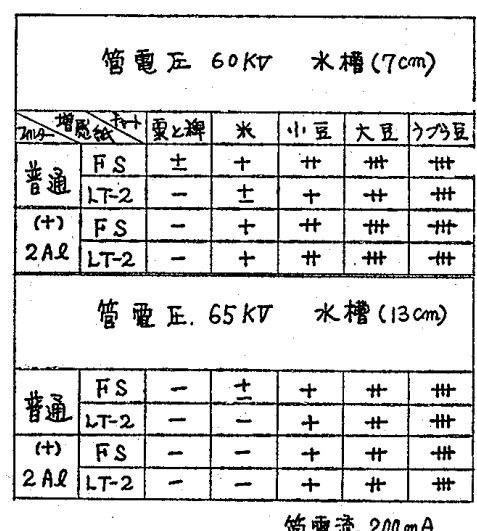

Fig. 112. 増感紙による比較 （款物法）

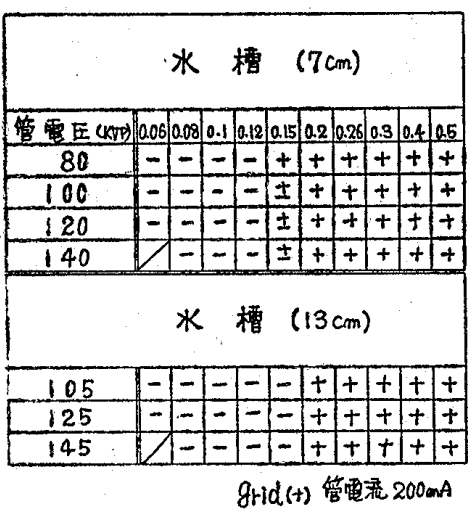

Fig. 115. フィルタ $(0.2 \mathrm{Cu}+2 \mathrm{Al})$ 使用時の示現（細線法） 


\begin{tabular}{|c|c|c|c|c|c|}
\hline \multicolumn{6}{|c|}{ 水 槽 $(7 \mathrm{~cm})$} \\
\hline 管電压( $\left(k_{p}\right)$ & 要上稗 & * & 小豆 & 大豆 & 325 五 \\
\hline 80 & $t$ & $t$ & \# & \# & \# \\
\hline 100 & \pm & \pm & $\#$ & \# & \# \\
\hline 120 & \pm & $t$ & \# & \# & +it \\
\hline 140 & \pm & $t$ & $\#$ & 世 & $\mathrm{H}$ \\
\hline \multicolumn{6}{|c|}{ 水 槽 $(13 \mathrm{~cm})$} \\
\hline 105 & $=$ & + & $\#$ & \# & 世 \\
\hline 125 & - & + & $\#$ & 世 & 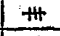 \\
\hline 145 & - & \pm & \pm & \# & \# \\
\hline
\end{tabular}

grid(t): 管電流 $200 \mathrm{~mA}$,

Fig. 116. フィルタ $(0.2 \mathrm{Cu}+2 \mathrm{Al})$ 使用時の示現（旐物法）

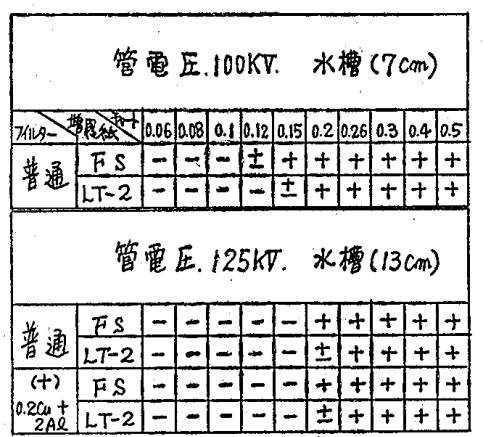

管要流 200mA:

Fig. 117. グリッド使用時の增感 紙による比較 (細線法)

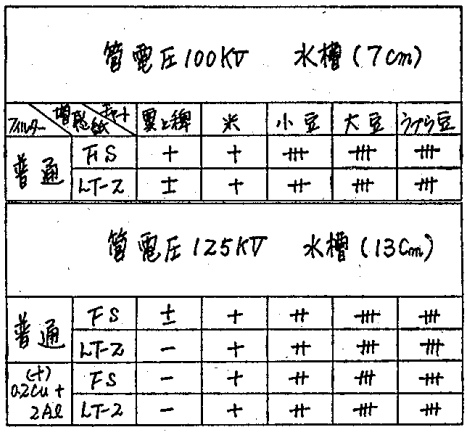

管要流200 mA .

Fig. 118. グりッド使用時の増感 紙による比較（穀物法）
現は良いが，水 $13 \mathrm{~cm}$ ではその差は殆んどない，而し管 電圧の上昇によって非常に細い細線チャ一トは素地黑化 度に抹消される傾向にある爯を周知して扔くべきで，乙 の事は試験用チャートの改善に重要な意義がある．次に 穀物法の結果は Fig. 114 でグリッドなしに比較して示 現はかなり向上している.また $\mathrm{Cu} 0.2+\mathrm{AL} 2 \mathrm{~mm}$ の附 加フィルタの結果は細線法ではFig. 115 で水7 cm で示

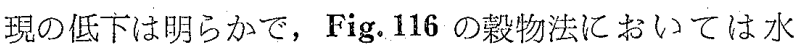
$13 \mathrm{~cm}$ で示現は悪くなる。

17-3 グリッド法のよる増感紙の示現 グリッドを使 月した場合の FS と LT-2 の示現を比較してみると Fig. 117は細線法で，Fig.118は款物法であるが共に FS が有 利である。

17-4 グレーデル法の示現＼cjkstart示現について F.F.D 250 $\mathrm{cm}$ で実験試みた。焦点 $1.2 \mathrm{~mm}$ を使用し、ファント ムフィルム間距離 $15 \mathrm{~cm}$ と $30 \mathrm{~cm}$ 亿おけるグレーデル法 で同じような英験を行なった。策騟結果は細線法で 15 $\mathrm{cm}, 30 \mathrm{~cm}$ 共直接法化比しかなの示現の低下である. また殸物法で，この湯合 AL $2 \mathrm{~mm}$ を附加したが， $65 \mathrm{kV}$ の場合滢汃ではあるが示現の问上になる。しかし一般的 に同一焦点ではグレーデル法は胸部撮影法に不利な点が 多い.

撮影法の相違による比䩙

\begin{tabular}{|c|c|c|c|c|c|c|c|c|c|c|c|c|c|c|}
\hline 万 & $40-1$ & & & & & & & & 10 & 5 5要和 & 米 & 㤱 & 大豆 & オブ語 \\
\hline \multirow[b]{2}{*}{ No.glid } & 65 & - & & & $1-$ & $t$ & $1+$ & +1 & + & - & \pm & $t$ & $\#$ & $m$ \\
\hline & 75 & - & & - & 7 & 7 & + & + & + & - & - & + & $\#$ & \# \\
\hline \multirow{2}{*}{ grid法 } & 125 & $1-$ & - & -1 & -1 & 7 & + & + & + & - & + & $\#$ & $\#$ & m \\
\hline & 145 & - & $1-$ & - & $T$ & F & t & + & & \pm & \pm & $\#$ & $\#$ & \#+ \\
\hline \multirow{2}{*}{$\begin{array}{l}(30 \mathrm{~cm} \\
\text { riv } \\
(250 \mathrm{~cm}\end{array}$} & 90 & - & - & - & 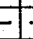 & - & $t$ & + & & - & \pm & + & + & HI \\
\hline & 115 & - & & & $t$ & & \pm & 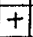 & + & - & \pm & + & $\pi$ & \# \\
\hline
\end{tabular}

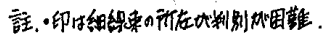

Fig. 119. 撮影法の相違による一例（水槽 $13 \mathrm{~cm}$ ）
今までの実験結果から代表的なものを比較してみると Fig. 119 のようになり Grid 法が水 $13 \mathrm{~cm}$ においては最 む良い結果である。

17-5 低濃度部の識別能 胸部写真は商濃度部を一定 浱度に抑え乍ら同時に心臓の後までの情報量を要求され る。その目的を達成する為の一手段として10円銅䝨によ る实験を試みた。

水ファントムとホトタイマを使用して撮影した銅貨の 影像をミクロメータで計测したのが Fig 120 で, 又銅貨

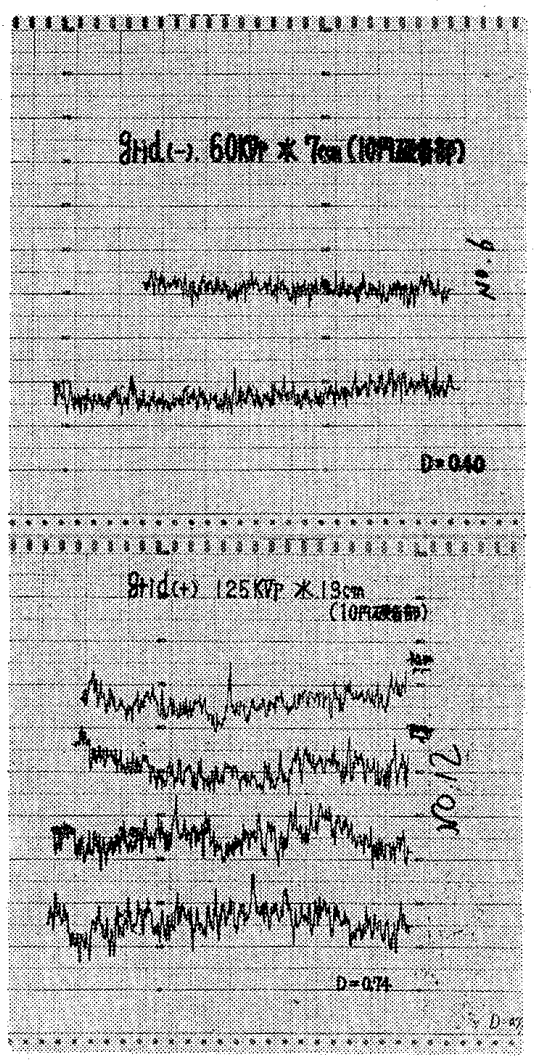

Fig. 120. 
に刻んである10の 字をフィルム包装 紙の上で反射光に より肉眼的に判定 した結果について 付水 $7 \mathrm{~cm}$ 加 Fig. 121 でo グリッ ドにおいては完全 に識別不能である がグリッド法に おいては $120 \mathrm{kV}$ が 最も識别し易く更 に3相と単相では 3 相の方が識別し 易い. 又水 $13 \mathrm{~cm}$ におい入ても $125 \mathrm{kV}$ が若干識別し易い.とこで特に銅貨部の濃度についてみ ると,グリッドなしの場合はグリッド法よりあ濃度は上 昇していても識別は出来ない。したがって低濃度部の情 報量を多くして診断能をあげる為にはグリッド法が有利 である。

17-6 小括 3相を主とした示現について小括してみ ると次のようになる。

イ）グリッドを使用しない場合

1. 水 $7 \mathrm{~cm}$ と $13 \mathrm{~cm}$ を比較すると, 細線法, 穀物法 共に $13 \mathrm{~cm}$ が示現が悪い.

2.アルミの附加フィルタで示現は僅かに低下する。

3. FS とLT-2では僅かにFS が有利である.

ロ）グリッドを使用した場合

1. 水 $7 \mathrm{~cm}$ 己 $13 \mathrm{~cm}$ の差は比較的少ない.

2. 款物法はグリッドなしに比較して示現は向上す る.

3.グリッドなしに比較してグリッド法が水 $13 \mathrm{~cm}$ で 有利である。

八) グレーデル法では

1. 直接法に比しグレーデル法の方が示現は悪い。

2. 管電圧 $65 \mathrm{kV}$ の穀物法でアルミの $2 \mathrm{~mm}$ の附加フ ィルタにより僅かに示現は良くなる傾向である.

3. 以上の結果から一般的胸部撮影法におりてはグレ ーデル法は不利である。

二）低濃度部について

1. 低濃度部の 10 円銅貨による実験の結果グリッド法 がはるかにすぐれ，黄紙上で10の字を反射光によっ て確認する事が出来，特に $120 \mathrm{kV}$ 附近が弁別し易
かった。

\section{8. 被曝量の問題について}

近年放射線による国民遺伝有意線量が問題になり診断 に执いても英国では奇型児対策として妊婦の胸部X線照 射の全面禁止が伝えられ，本邦においても患者被曝防護 のためのX線診断として，日医検討委員会の答申が日本 医事新報 No. 2612 号に報告されている．との報告で 3 相電源又は 3 相装置を用いる事が好ましい事を報告して いる. そこで実際面から単相と 3 相12パルスについて比 較検討を試みた。

18-1 単相装置による空中線量，単相装置の空中線量 について, 日常 FS 増感紙使用時の胸部撮影条件を基に 測定器はコロニアル線量計を用い, 測定距離は正面の場 合， $180 \mathrm{~cm}$ ，側面は $160 \mathrm{~cm}$ の位置で測定したその結果 は Table. 15 と Table. 16 の通りであるが，正面の場合 は大約 $20 \sim 80 \mathrm{mR}$ で，又側面の場合は $140 \sim 220 \mathrm{mR}$ で ある．との測定結果から胸厚別にグリッドを使用した場 合の管電圧による線量をモデル的に作図してみると Fig. 122 が胸厚 $18 \mathrm{~cm}$ ，Fig. 123 が胸厚 $21.5 \mathrm{~cm}$ の場合であ るが，水平に記入した線量はグリッドなしの標準撮影条

Table. 15 胸部撮影時の空中線量の一例 (単相 500MA型)

\begin{tabular}{|c|c|c|c|c|}
\hline $\begin{array}{c}\text { 管電 } \\
(\mathrm{kV})\end{array}$ & $\begin{array}{c}\text { 管 電 流 } \\
(\mathrm{mA})\end{array}$ & 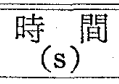 & $\begin{array}{l}\text { 測定距離 } \\
(\mathrm{cm})\end{array}$ & 線 $(\mathrm{R})^{\text {量 }}$ \\
\hline 55 & 250 & 0.1 & 180 & 0.022 \\
\hline 58 & 250 & 0.1 & 180 & 0.026 \\
\hline 63 & 250 & 0.1 & 180 & 0.03 \\
\hline 68 & 250 & 0.1 & 180 & 0.038 \\
\hline 73 & 250 & 0.1 & 180 & 0.042 \\
\hline 70 & 200 & 0.1 & 180 & 0.032 \\
\hline 73 & 200 & 0.1 & 180 & 0.034 \\
\hline 78 & 200 & 0.1 & 180 & 0.04 \\
\hline 83 & 200 & 0.1 & 180 & 0.046 \\
\hline 87.5 & 200 & 0.1 & 160 & 0.06 \\
\hline 95 & 200 & 0.1 & 160 & 0.072 \\
\hline 102.5 & 200 & 0.1 & 160 & 0.08 \\
\hline 110 & 200 & 0.1 & 160 & 0.047 \\
\hline 118 & 100 & 0.1 & 160 & 0.056 \\
\hline 125 & 100 & 0.1 & 160 & 0.06 \\
\hline 125 & 50 & 0.1 & 160 & 0.03 \\
\hline 130 & 50 & 0.1 & 160 & 0.034 \\
\hline 135 & 50 & 0.1 & 160 & 0.038 \\
\hline 135 & 50 & 0.06 & 160 & 0.021 \\
\hline 140 & 50 & 0.06 & 160 & 0.022 \\
\hline 145 & 50 & 0.06 & 160 & 0.024 \\
\hline
\end{tabular}


Table. 16 側面撮影時の空中線量の一例 (単相 $500 \mathrm{~mA}$ 型)

\begin{tabular}{|c|c|c|c|c|}
\hline $\begin{array}{c}\text { 管 電 圧 } \\
(\mathrm{kV})\end{array}$ & $\begin{array}{c}\text { 管 電 } \\
(\mathrm{mA})\end{array}$ & $\begin{array}{l}\text { 時 }(\mathrm{S})^{\text {間 }} \\
\text { ( }\end{array}$ & $\begin{array}{c}\text { 測定距離 } \\
(\mathrm{cm})\end{array}$ & 線 $(R)^{\text {量 }}$ \\
\hline 120 & 100 & 0.2 & 150 & 0.14 \\
\hline 130 & 100 & 0.2 & 150 & 0.17 \\
\hline 140 & 100 & 0.2 & 150 & 0.19 \\
\hline 145 & 50 & 0.4 & 150 & 0.22 \\
\hline 135 & 100 & 0.2 & 150 & 0.18 \\
\hline 140 & 50 & 0.4 & 150 & 0.20 \\
\hline
\end{tabular}
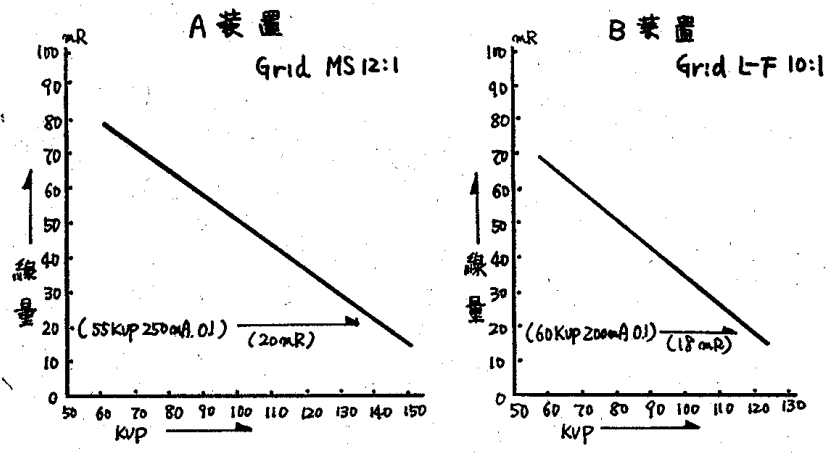

Fig. 122. 胸厚 $18 \mathrm{~cm}$
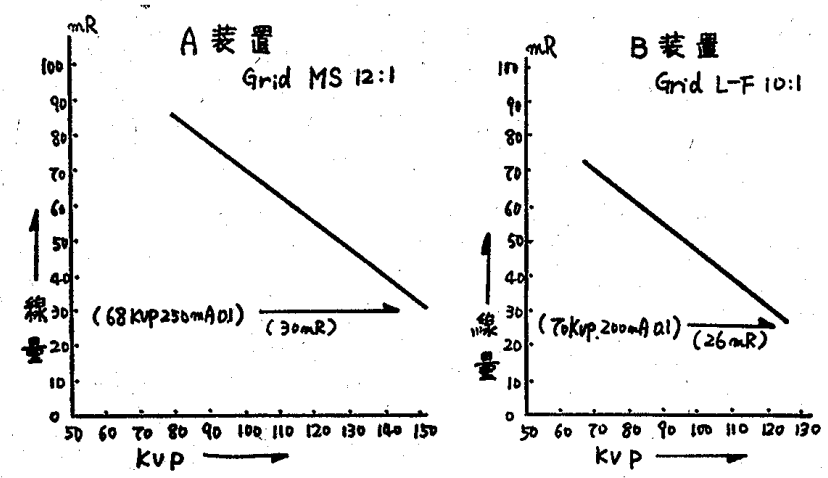

Fig. 123. 胸厚 $21.5 \mathrm{~cm}$

件で装䈯間に多少の線量の相違はみられる.

18-2 グリッド使用時の単相装置における線量 グリ ッド12:1を使用してホトタイマにより可能な限り写真効 果が同一になるような螢光量を用いて水ファントムの表 面における線量を極光 TLD，線量計によって測定した。 又測定線量はTLD 3 本以上の 平均值で求めた。 その結 果はFig. 124 で普通フィルタ水 $7 \mathrm{~cm}$ で $80 \mathrm{kV}$ の時 56.1 $\mathrm{mR} 140 \mathrm{kV}$ で $32 \mathrm{mR}$ であった. Fig. 125 は水 $13 \mathrm{~cm}$ で, 銅 $0.2+$ アル $2 \mathrm{~mm}$ の附加フィルタで $80 \mathrm{kV} 128.8$ $\mathrm{mR}, 140 \mathrm{kV}$ で $81.4 \mathrm{mR}$ である. 又下段は $1 / 2$ 螢光量の 場合である。

18-3 単相装置による管電圧の減少率について 先の

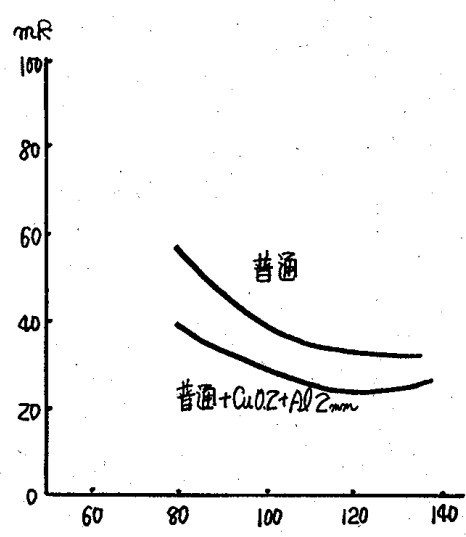

Fig. 124. 水槽 $7 \mathrm{~cm}$ 表面における線量（単相Grid゙)

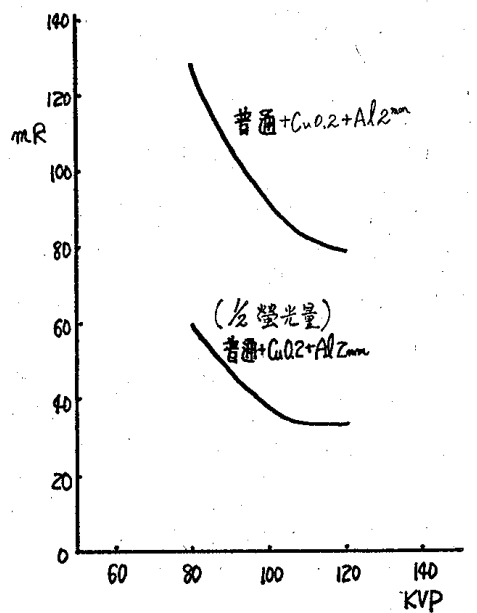

Fig. 125. 水槽 $13 \mathrm{~cm}$ 表面にお晾る線量(単相 Grid)

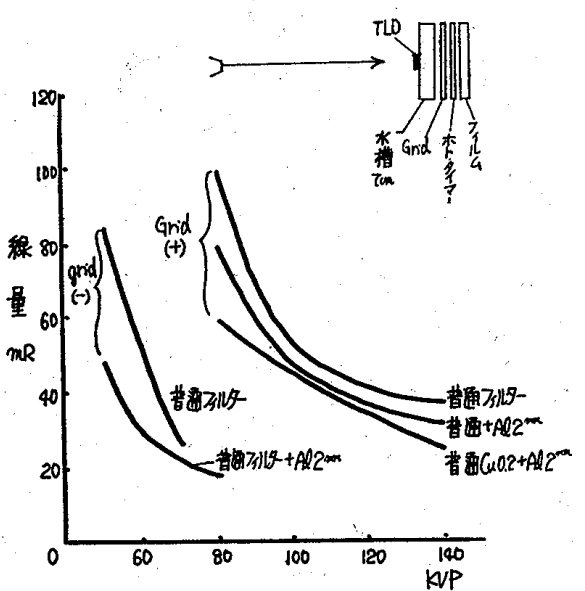

Fig. 126. 水槽 $7 \mathrm{~cm} の$ 表面における線量

測定值をもとに単相装置で管電圧による影響を比較した。 水 $7 \mathrm{~cm}$ の場合 $80 \mathrm{kV}$ を100\%とすると, 普通フィルタの 場合 $140 \mathrm{kV}$ 亿なると約 $57 \%$ であ. 又銅 $0.2 \mathrm{~mm}+$ アル ミ2 mm で約62\%となる。

18-4３相12パルスによる線量 単相と同じ測定法で極 
光 TLD 使用して水ファントムの表面に㧍汀る線量を 測定した結果は Fig. 126 で水 $7 \mathrm{~cm}$ の場合グリッド(一) では $50 \mathrm{kV}$ で $84.7 \mathrm{mR}$ であるが 電圧の上昇と共に， 70 $\mathrm{kV}$ で $26.2 \mathrm{mR}$ と線量は急に減少する.アルミ $2 \mathrm{~mm}$ の 附加フィルタの使用で $50 \mathrm{kV}$ は $48.3 \mathrm{mR}, 70 \mathrm{kV}$ では $22.1 \mathrm{mR}$ で普通フィル゙タの場合に比しかなりの相違があ る. 又グリッド(十)では $80 \mathrm{kV}$ では $99.5 \mathrm{mR}$ であるが アルミ $2 \mathrm{~mm}$ の附加フィルタで $79 \mathrm{mR}$, 更に鉰 $0.2+ア$ ルミ $2 \mathrm{~mm}$ の附加フィルタで $59.2 \mathrm{mR}$ であった. 又電圧 が $140 \mathrm{kV}$ の場合普通フィルタで $36.5 \mathrm{mR}$, アルミ $2 \mathrm{~mm}$ の附加で $31.9 \mathrm{mR}$, 銅 $0.2 \mathrm{~mm}+$ アル $\Sigma 2 \mathrm{~mm}$ の附加で $24.2 \mathrm{mR}$ とフィル夕による線量の減少は非常に大きい.

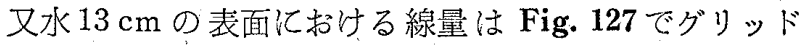

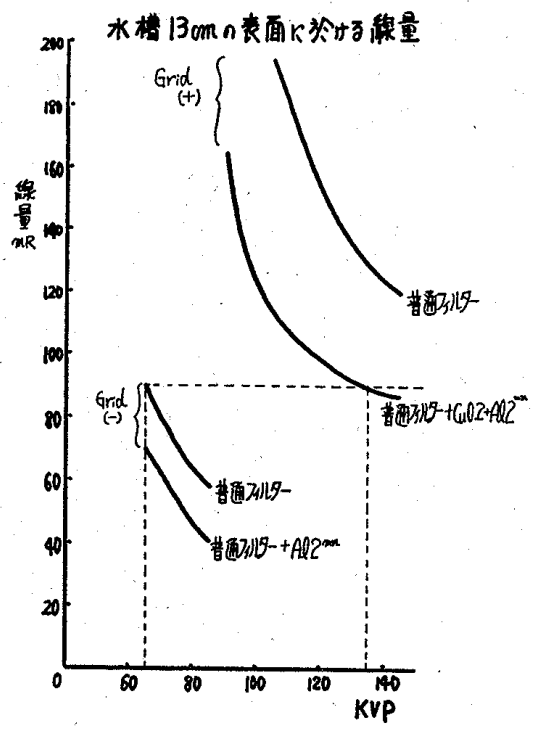

Fig. 127. 水槽 $13 \mathrm{~cm}$ の表面に抬ける線量

(一)では $65 \mathrm{kV}$ で, $90 \mathrm{mR}, 85 \mathrm{kV}$ で $58.9 \mathrm{mR}$ である. 又ァルミ $2 \mathrm{~mm}$ の附加フィルタで $65 \mathrm{kV}$ で $69.9 \mathrm{mR}$, $85 \mathrm{kV}$ では $40.1 \mathrm{mR}$ である.グリッド(十)の場合は 90 $\mathrm{kV}$ で $291 \mathrm{mR}, 145 \mathrm{kV}$ で $119.4 \mathrm{mR}$ であった．次に銅 0.2 $\mathrm{mm}+$ アルミ $2 \mathrm{~mm}$ の附加で $90 \mathrm{kV} 164.3 \mathrm{mR}, 145 \mathrm{kV}$ で は $87.8 \mathrm{mR}$ であった。

18-5 電圧による減少率 先の測定値をもとに表面に おける線量の最低電圧を $100 \%$ として電圧による比較を した：その結果水 $7 \mathrm{~cm}$ の場合がグリッド(一)普通フィ ルタで $50 \mathrm{kV}$ から $60 \mathrm{kV}$ 亿電圧を上昇する事によって約 60\%の表面における線量である. 又グリッド(十)の場合 $80 \mathrm{kV}$ 加ら $120 \mathrm{kV}$ 亿電圧を上昇する事により普通フィ ルタで $47 \%$, アルミ $2 \mathrm{~mm}$ 附加で $40 \%$ 銅 $2 \mathrm{~mm}+$ アル $2 \mathrm{~mm}$ の附加で57\%となる。したがって比較的低圧側で はフィルタによる減少が大きいので電圧による減少率は

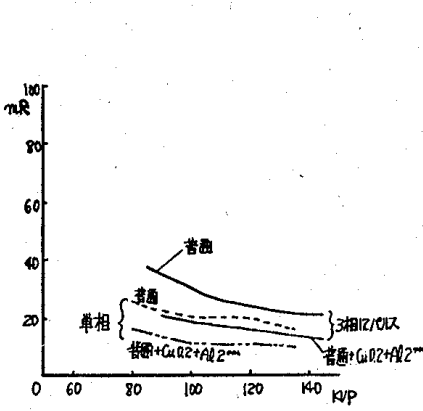

（水榑 $7 \mathrm{~cm}$ )

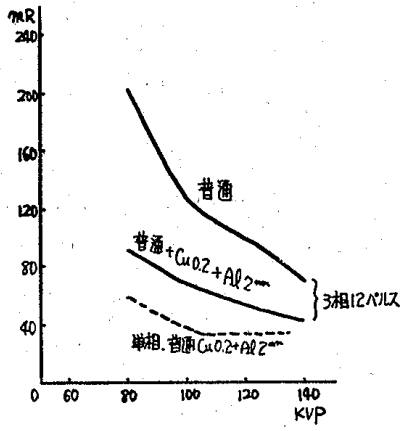

（水槽 $13 \mathrm{~cm}$ )
Fig. 128. 1/2 螢光量における線量比較
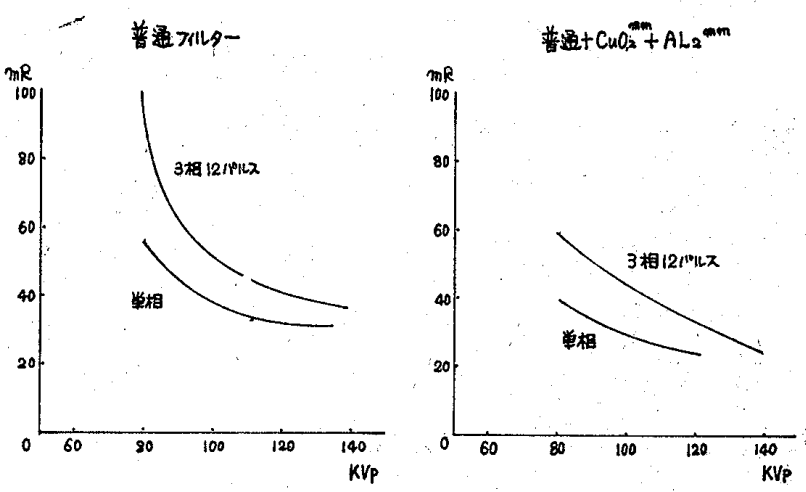

Fig. 129. 三相12パルスと蒴相装置の線量比較 （水槽 $7 \mathrm{~cm}$ グリッド $($ 一)
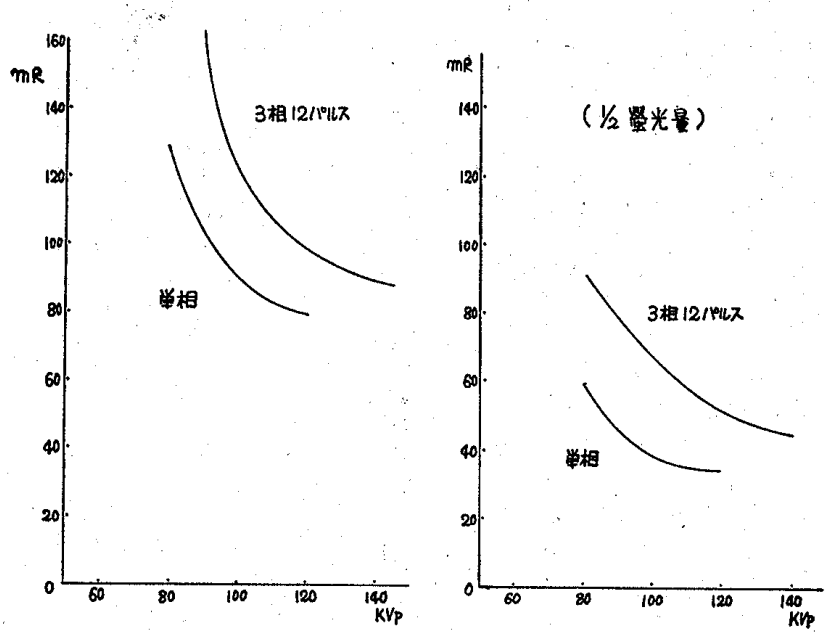

Fig. 130. 三相12パルスと単相の線量比較（水槽 $13 \mathrm{~cm}$ ，普通 $+\mathrm{Cu} 0.2 \mathrm{~mm}+\mathrm{A} 12 \mathrm{~mm}$ )

附加フィルタの厚さが厚くなればなる程小さくなる．水 $13 \mathrm{~cm}$ の減少率はグリッド(ー)では $65 \mathrm{kV}$ から $80 \mathrm{kV} の$ 上昇でアルそ $2 \mathrm{~mm}$ で略々 $60 \%$, 又グリッド(+)では $90 \mathrm{kV}$ から $125 \mathrm{kV}$ で約 $50 \%$ ある.

18-6 1/2螢光量による線量 従来 FS 増感紙を基本に して胸部撮影を実施しているのが一般的な現状で LT-2 
の出現により, 濃度曲線からは59～63\%になり, 更に現 像温度を低くした処理法の場合略々50\%で撮影できる. そこでホトタイマを使用して水ファントムの表面におけ る線量を測定した。その結果はFig. 128 て水 $7 \mathrm{~cm}$ と $13 \mathrm{~cm}$ でいずれもグリッドを使用したものであるが表面 における線量す略々 $1 / 2$ でる。

18-7 3 相と単相の線量比較 以上の測定結果から 3 相と単相を一表にして水 7cmを比較したものが Fig. 129 でフィルタを使用する事によって線量はかなり減少して いる. 又水 $13 \mathrm{~cm}$ の場合の比較が Fig. 130 である.この 実験においては，単相よりも 3 相 12 パルスの方が線量は 多い.

18-8 立証実験 “次に単相と 3 相の線量比較実験にお

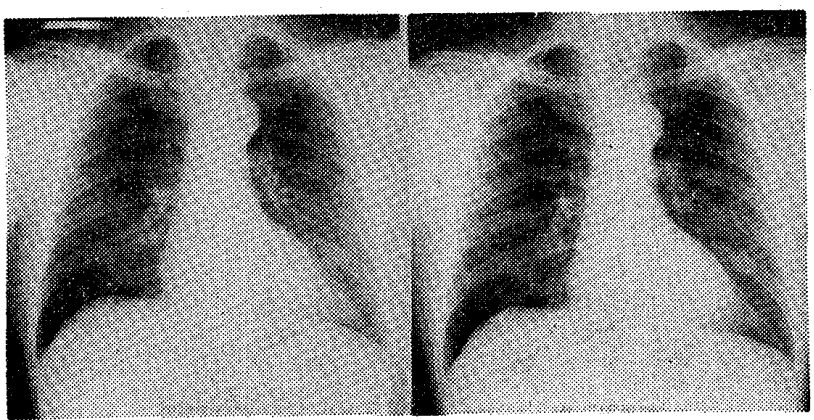

Fig. 131.

Table. 17 写真効果加らみた表面に於ける線量

\begin{tabular}{|c|c|c|c|c|c|}
\hline $\begin{array}{l}\text { ホト夕 } \\
\text { イマー } \\
\text { タップ }\end{array}$ & $\begin{array}{l}\text { 水槽 } \\
\mathrm{cm}\end{array}$ & フィルタ & $\begin{array}{l}\text { グリ } \\
\text { ッド }\end{array}$ & $\mid \begin{array}{c}\text { 管電压 } \\
\mathrm{kV}\end{array}$ & $\begin{array}{l}\text { 線量 } \\
\mathrm{mR}\end{array}$ \\
\hline 7 & 13 & 普: 通 & $(-)$ & 60 & 127.1 \\
\hline 7 & 13 & 普通+ $\mathrm{Al} 2 \mathrm{~mm}$ & $(-)$ & 60 & 83.9 \\
\hline 6 & 13 & 普: 通 & $(+)$ & 125 & 130.8 \\
\hline 5 & 13 & $\begin{array}{r}\text { 普通 } \mathrm{Cu} 0.2+ \\
\mathrm{Al} 2 \mathrm{~mm}\end{array}$ & $(+)$ & 125 & 86.5 \\
\hline
\end{tabular}

けるホトタイマの精度について，同一被写体で 比較した胸部写真が Fig. 131 である.

18-9 写真効果からみた線量 胸部撮影の場 合グリッド(一)とグリッド法附加フィルタの種 類，管電圧等によって線量が異なるが，ホトタ イマによって濃度が略々一定になるようにした 水 $13 \mathrm{~cm}$ の表面における線量は Table 17 で, 同一被写体です撮影手技の選扒によってとのよ うに線量は異なる。

18-10 考察，一般に理論的々は 3 相裝置の方 が単相装置に比し被曝量は少ないと云われ乍ら 螢光量を可能な限り一定にした，水フヌントム の表面に打ける線量は単相装置の方が少なかっ

た。

これは結果的には，

1，3 相12パルスの波型が悪い事

2. 多重えラーの厚さが異なる事

3. 撮影台の機構が多少異なる事

4.グリッドメーカーが異る事

5. 3 相と単相の特性が異なる事

6. 装置間の螢光量特性曲線が異なる事

等に起因するものと考えられる。したがって多重のミラ 一の規格化，3相装置の波型の問題，電源等基礎的な問 題が解決されないと装置の方式だけでは実際の被曝量軽 減にはならないようである。

18-11 小括 被曝量について実際の胸部撮影条件を基 礎に水ファントムを利用した測定結果を小括してみる と,

1. 3 相装置といえどあ水ファントムの表面における 線量は必ずしも少なくならない。

2. 本実験においては 3 相 12 パルスに比䩙して単相装 置の方が表面における線量は少ない。

3. 附加フィルタによりかなり線量を減少出来る。

4. 増感紙をLT-2 にすると表面における線量はFS の略 $2 / 3 \sim 1 / 2$ に減少出来る.

\section{9. 撮影体位と障害陰影}

胸部撮影体位の代表的なものとして

1.手を腰にあてる方法

2、撮影台をだかせる方法

であるが後者は老人向体位で利用度も高い。そこでこの 体位によって障害陰影の現出の調査を試みた. 判定の基 準は肩胛骨が肺野内にある場合は肩，鎖骨は上端が第 1 肋骨の内側之第 4 肋骨交攴点より上にある場合は位圆不

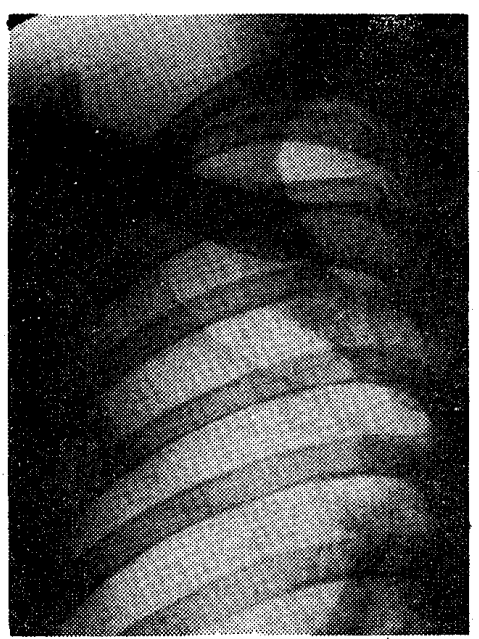

Fig. 132.

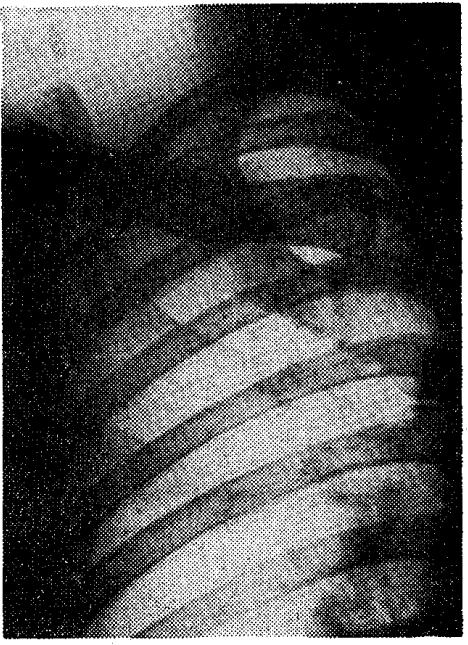

Fig. 133. 


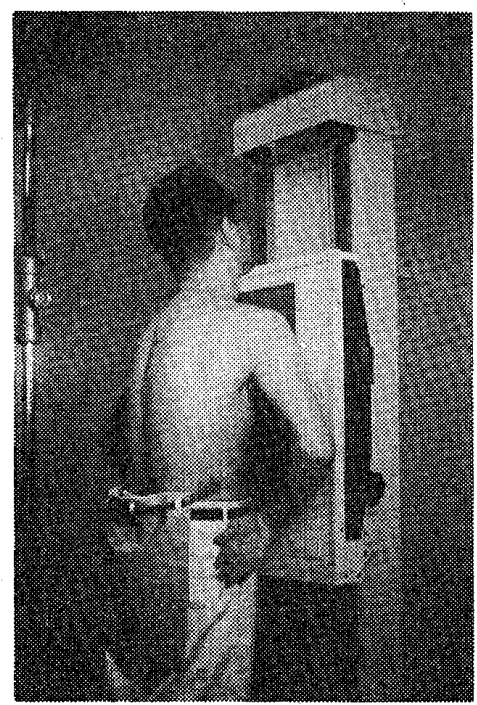

障 害 陰 影 鎖骨の位䈏不良

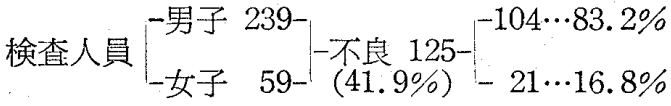
肩胛骨の現出能

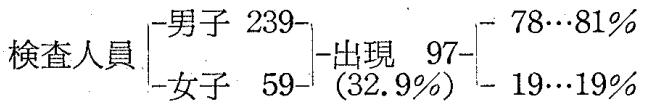

Fig. 134.

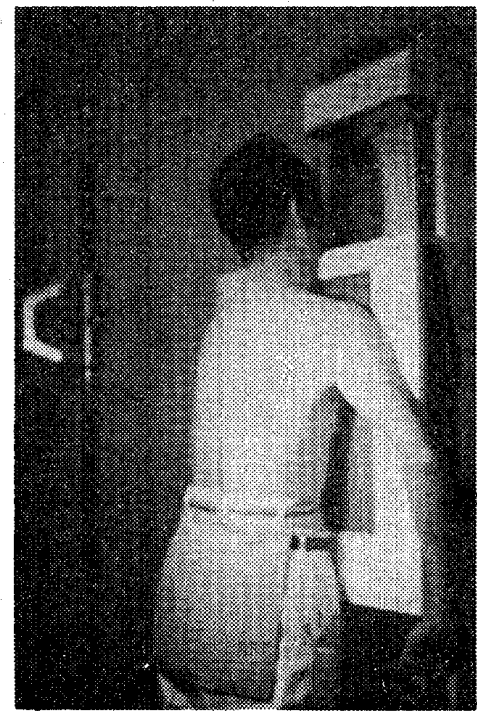

障害陰影（第 2 体位）

鎖骨の位䈯不良

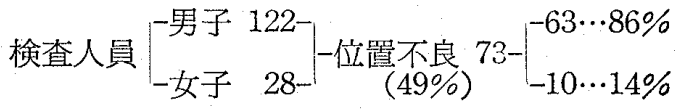

彦胛骨の出現

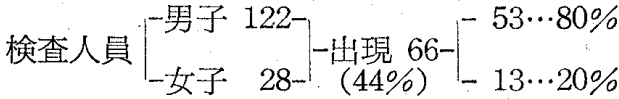

Fig. 135 .

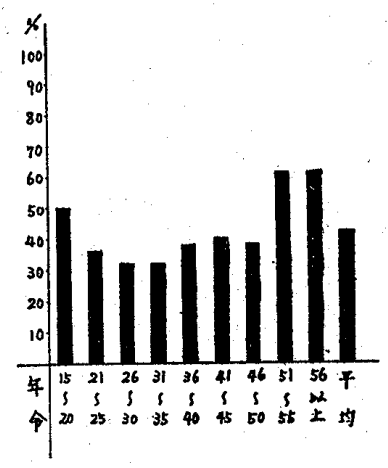

鎖骨の位置不良

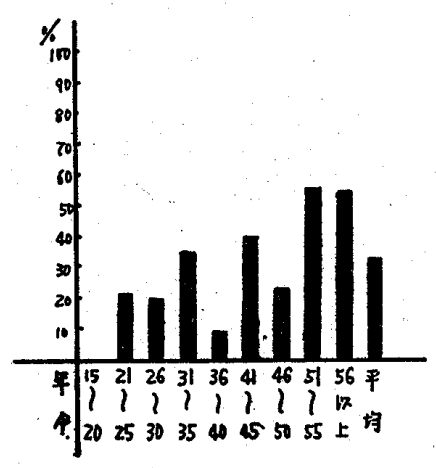

肩胛骨の現出能
Fig. 136
胸厚別肩胛骨現出能

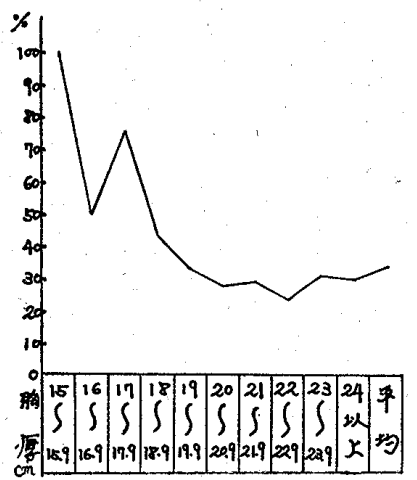

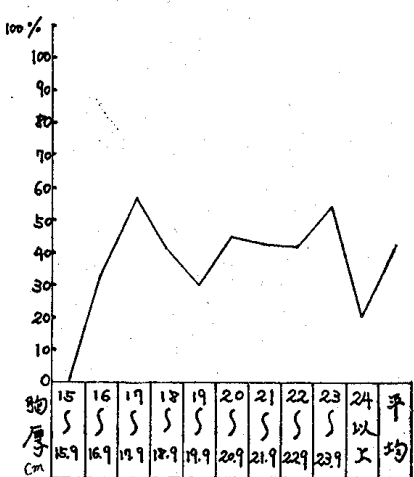

胸厚別鎖骨の位㯰不良
Fig. 137.

良として集約した，Fig. 132 は鎖骨，肩胛骨共に良好な 写真であるが Fig. 133 牥不良の写真である. その結果は Fig. 134で，手を腰に当てた場合で鎖骨位置不良は 41.9 \%，肺野内に肩胛骨が認められるもの $32.9 \%$ ある。 Fig. 135 は撮影台をだかせる方法に执いては鎖骨位置不 良 $49 \%$ 肩胛骨 $44 \%$ が肺野内に認められた。次に年秢別集 計が Fig. 136 で位置不良は高龄者に多い. 更に Fig. 137 のように胸愿別に分類してみると肩胛骨では胸厚が厚く なると肺野内の陰影は比較的少なく，又鎖骨についてす 厚さによる差は比較的少ない。

Table. 18 肺野中，骨㓌影の重なる割合

\begin{tabular}{|c|c|c|c|c|c|}
\hline & & $\begin{array}{l}\text { 骨影の } \\
\text { tる(場 } \\
\text { 合 }\end{array}$ & $\begin{array}{l}\text { 骨影力゙ } \\
\text { 部塹 }\end{array}$ & $\begin{array}{l}\text { 骨影力゙ } \\
\text { 動の } \\
\text { 部分 }\end{array}$ & $\begin{array}{l}\text { 骨影が } \\
\text { 重の } \\
\text { 部分 }\end{array}$ \\
\hline \multirow{2}{*}{$\begin{array}{l}\text { 右 } \\
\text { 腣 } \\
\text { 野 }\end{array}$} & 脑尖及び上肺野 & $20.7 \%$ & $42.5 \%$ & $30.6 \%$ & $6.2 \%$ \\
\hline & その他の肺野 & $38.1 \%$ & $47.3 \%$ & $14.6 \%$ & \\
\hline \multirow{2}{*}{$\begin{array}{l}\text { 左 } \\
\text { 奣 } \\
\text { 野 }\end{array}$} & 肺尖及び上肺野 & $21.9 \%$ & $44.5 \%$ & $28.1 \%$ & $5.5 \%$ \\
\hline & 〈その他の肺野 & $34.2 \%$ & $48.7 \%$ & $17.1 \%$ & \\
\hline
\end{tabular}

（鶴田氏による） 


\section{0. 肺野における骨陰影の比率}

胸部X線写真において最も問題の多い骨陰影について みると Table. 18 のように骨と重なって陰影される部分 が約60\%で，乙の障害陰影を出来るだけ減少させる事も 胸部撮影技術の重要な点である.

\section{1. 胸部写真における読影の要点}

胸部 X線写蒖読影時よ゙のような点について判断してい るか熟知しておく必要があり，てれを要約したものが Table.19で，乙れらの点が確実に分析されなければ胸 部写真としては不充分である.

Table. 19 胸部写蒖の読影の要点

\begin{tabular}{|c|c|c|}
\hline 1. & 骨 性 胸 部 & 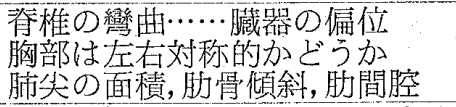 \\
\hline 2. & 横 隔 膜 陰 影 & 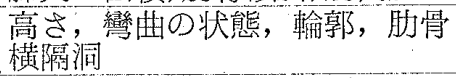 \\
\hline 3. & 中央陰影の観察 & $\begin{array}{l}\text { 気管の位置，心蔵の位置，形， } \\
\text { 辺緣の境界 }\end{array}$ \\
\hline 4. & 肺 門 陰 影 & $\begin{array}{l}\text { 位置, 形, 大きさ（特に乳奻坚 } \\
\text { (は注意) }\end{array}$ \\
\hline 5. & 肺 & 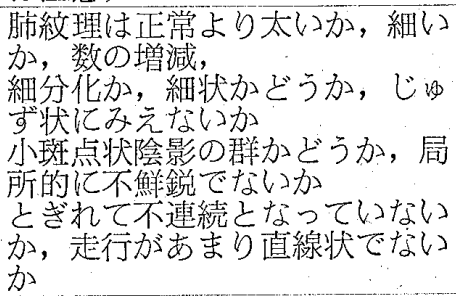 \\
\hline
\end{tabular}

\section{2. 臨床写真について}

胸部X線診断の場合臨床的飞写真濃度は，どの程度が 良しかはしばしば議論の別れる処であるが前述のコント ラストの処でものべたように単相と 3 相とでは濃度特性 は多少異なり，特にグリッドを使用した場合明白で，肺 野の高濃度部を基準にするか，低濃度部を基準にするか でも濃度は違ってくる.今胸部写真で最屯臨休医の好む 濃度を一表にしたすのが Table. 20 である.しかし単相 に於ては高濃度部を同一にすれば低濃度部で 3 相よりあ

Table. 20 肺野の至適浱度

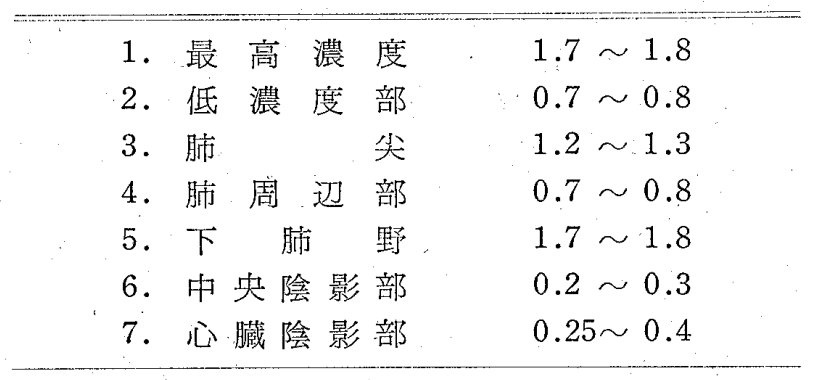

或程度濃度は上昇し，逆に低濃度部を一定にすれば高濃 度部では0.1〜0.2程度濃度は低くなる傾向にある.しか しいずれにしても最高濃度 2 以上の写真は濃度過多であ る. 今臨床的筧容度の略々最低之最高の濃度と考えられ る写真についてみると Fig. 138が至邀濃度の内でも比較 的高い 1.8 1.9附近の写真で, Fig 139 が比較的低い方 に属す1.6〜1.7附近の写真である. 又参考までにミク口 フォトメータによる莀度測定の一例が Fig.140である。

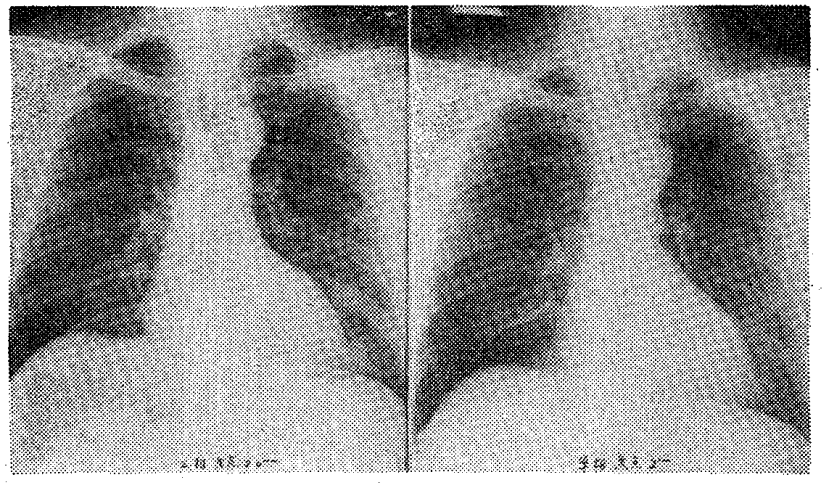

Fig. 138.

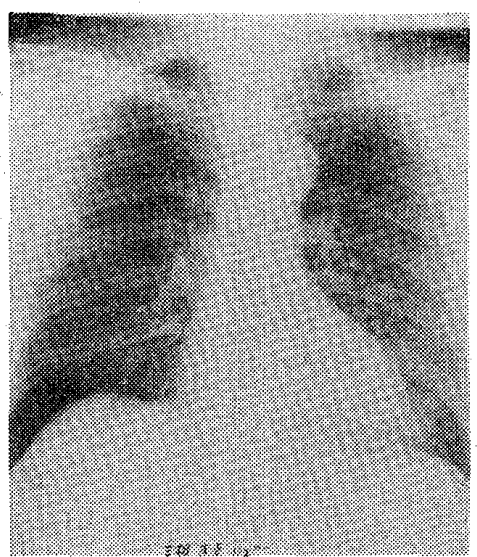

三相12パルス

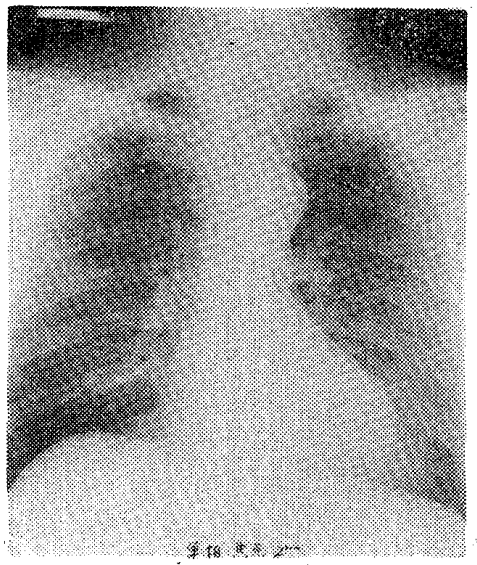

単 相

Fig. 139 


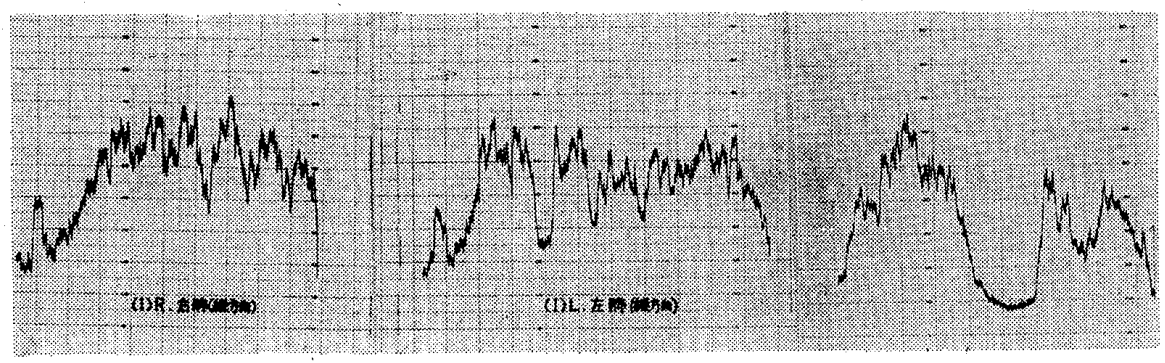

Fig. 140.

し心から御礼を申し上げる次第 です.

\section{参考文献}

1) 御園生圭輔著：胸部 $\mathrm{X}$ 線写 真のみかた，結核予防会

2) 田坂清一著: 肺結核のX線 技術の理論之実際, 医学畫 院.

\section{3. 総括, 結言}

胸部撮影法にお和現状之問題点や意見, 更に実際に 直結した問題で幾何学的問題, 感光材料, 粒状性, 造影 鼡, 散乱線関係, 線量制御法, 被曝量等についてのべた が，現状に㧍けるX線写真に昖いてその利用度は最高で あるとし作らも業務の単調性と慣習にとらわれ易く，今 日尚問題が多く残存し，理論面と現実の間にはかなりの ギャップが䜑められる。特に二次投入式 3 相 12 パルスの 波形問題や，タイマー問題，線量制御法の分割測光式問 題被曝量等で，元よりX線技術は理論と現実とが一致し てとそ進歩する事を考えれば，乙れらの基本的技術問題 の解決こそ急務で関係者に強く要望したい. 又胸部撮影 法は究極の目標達成の為には基本を忠実沱り怎万正確 なる資料と絶まざる努力によってのみ実現可能で，一般 的には被懪量減少之画質の問題は相反する関係が多く存 在するので，その実際に於ては被曝量を充分に配慮じ乍 らむ診断が最も優先すべきで胸部撮影法に於ては，更に 一段之技術の改善之画質の向上を計り，屯って国民医療 に貢献すべきであると考える次第です。

\section{4. 謝 辞}

日本医学会総会と時を同じく開催された第31回曰本放 射線技術学会総会において宿題報告の機会を与えていた だいた坦鍔会長，並びに役員諸氏に深进なる感謝の意を 捧げます、・本研究実施に当り貴重な施設の使用をお許し 顶いた共済組合清瀬病院長香川修事博士並びに御支援, 御協力を賜りました東圤放射線株式会社, 島津製作所, 大日本签料株式会社，スライド作製に協力頂いたフシ X レイ株式会社, 資料の提供を頂りた千代田日エイ株式会 社, 東洋レントゲン株式会社, 並びにアンケートに協力 頂いた会員各位に対し心から敬意と感謝の意を表します。 又本研究に際し種々御理解之御便宣を頂いた府中病院長 石川幸雄博士, 放射線科医長福本義明博士, 実験に拹力 頂いた清瀨病院五十城耕平主任, 鈴木澄雄, 松村潔技師, 府中病院古田豊里主任, 岩下登, 奥倉修技師外一同飞対
3) 内藤普夫：気管支造影法, 医学書院.

4) 江藤, 吉村訳：エックス線写真撮影法の実際的諸問 題, 克誠堂.

5) 江藤外編集：放射線医学(第 1 部X線による䛦断), 医学書院.

6）横井, 福田：人体 $\mathrm{X}$ 線撮影法, 南江堂.

7）岡西順二郎：肺結核のレントゲン鑑別診断, 南江 堂.

8）野辺地他：臨㕅にお污万放射線の最近の動向，金原 出版KK.

9）網川高美：肺臟撮影条件決定の基檚，日放技特集第 1 号, 531-64-72.

10) 中島良貞他: 肺ノレ線写真撮影法, 日医放, 第 1 巻, 3 号.

11）江藤秀雄：高圧撮影法の基礎的知識，日放技特集， 第 2 号.

12）营原：努他：高圧撮影法に関する技術的亚びそ臨休 的問題, 日放技, 特輯, 第 2 号.

13). 竹吉干市: 胸部撮影法の検討第 1 報, 日放技, 第 12 巻, 1 号.

14）竹吉千市：胸部撮影法の検討第 2 報, 日放技，第 13 巻, 3 号.

15）細江謙三他：焦点の大きさと撮影距離の解像力に及 ぼす影響について, 日放技, 第14巻 3 号.

16）草皆太平：胸部 $\mathrm{X}$ 線撮影時の散乱線の状態について, 日放技，第16巻， 2 号.

17）竹吉千市：胸部撮影法の検討第 3 報, 日放技, 第17 巻 1 号.

18）細江謙三他：撮影時における被曝線量とつィルター の関係につにて, 日放技, 第 7 巻, 1 号.

19）林 周二: X線写真像示現の限界, 日放技, 第17巻, 3 号.

20）中村：実：X線撮影《おける被検者の被曝量減少に 関する基礎的研究, 日放技, 第17巻, 3 号, 第 18 巻, 1 号. 
21）藤沢謙三郎：X線撮影時におけるフィルムに及ぼす 散乱線の影響について，日放技，第17巻，4号.

22）福田徹夫他：Xレイコンテスト入選胸部写真の濃度 について，日放技，第19巻 5 号.

23）中村 実：X線写真の画質に及ぼす因子の研究，日 放技, 第 20 巻, 4 , 号.

24）笹沢輝昭：胸部写真の調査と濃度に関する研究，日 放技，第28回総会抄録.

25）大塚炤義： 3 相12パルス装置のX線出力, 日放技, 第28回総会抄録.
26）野崎秀英：過去半世紀レ線の発達，さくらXレイ研 究 2 号, 1950-11.

27) 高野正雄：X線写真像の画質評価法之要因の解析そ ๑ 1, 1973, No.101.

28）高野正雄：X線写真像の画質評価法と要因の解析そ ๑ 2, 1974, No. 102 .

29）高野他：Radiograph に抹ける Graininess と sharpness の検討，日放技，第29回総会抄録。

30) C. Clark.: Positionig in Radiography. （線量制御法関係については文献省略） 